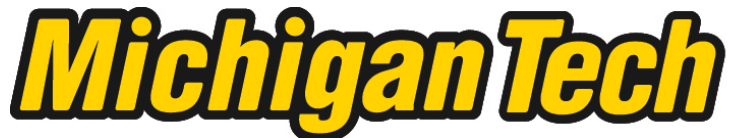 \\ Michigan Technological University Create the Future Digital Commons @ Michigan Tech
}

Development of an optimization model for biofuel facility size and location and a simulation model for design of a biofuel supply chain

Fengli Zhang

Michigan Technological University

Follow this and additional works at: https://digitalcommons.mtu.edu/etds

Part of the Mechanical Engineering Commons

Copyright 2011 Fengli Zhang

Recommended Citation

Zhang, Fengli, "Development of an optimization model for biofuel facility size and location and a simulation model for design of a biofuel supply chain", Master's report, Michigan Technological University, 2011.

https://doi.org/10.37099/mtu.dc.etds/555

Follow this and additional works at: https://digitalcommons.mtu.edu/etds

Part of the Mechanical Engineering Commons 


\title{
DEVELOPMENT OF AN OPTIMIZATION MODEL FOR BIOFUEL FACILITY SIZE AND LOCATION AND A SIMULATION MODEL FOR DESIGN OF A BIOFUEL SUPPLY CHAIN
}

\author{
By \\ Fengli Zhang \\ A REPORT \\ Submitted in partial fulfillment of the requirements for the degree of \\ MASTER OF SCIENCE \\ Mechanical Engineering
}

MICHIGAN TECHNOLOGICAL UNIVERSITY

2011

(C) 2011 Fengli Zhang 
This report, "Development of an Optimization Model for Biofuel Facility Size and Location and a Simulation Model for Design of a Biofuel Supply Chain,” is hereby approved in partial fulfillment of the requirements for the Degree of MASTER OF SCIENCE IN MECHANICAL ENGINEERING.

Mechanical Engineering-Engineering Mechanics

Signatures:

Report Advisor

Dana M. Johnson

Report Co-Advisor

John W. Sutherland

Department Chair

William W. Predebon

Date 


\section{Table of Contents}

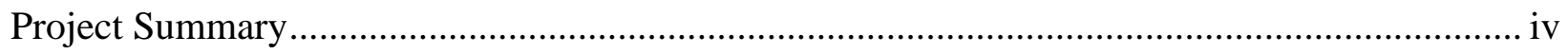

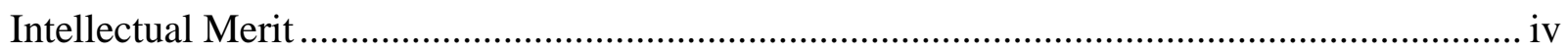

Broader Impacts .................................................................................................................. iv

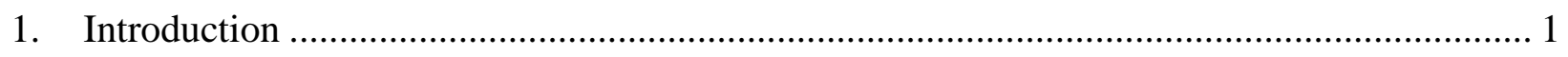

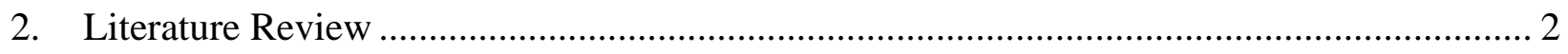

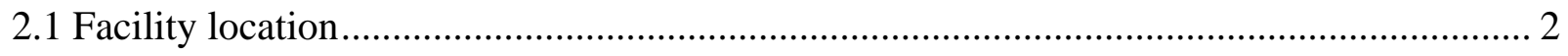

2.2 Supply chain model ......................................................................................................... 4

3. Research Objective ..................................................................................................... 6

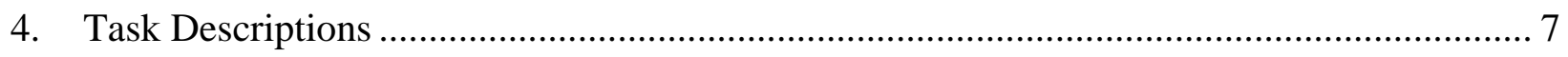

Task 1: Identify Candidate Biofuel Facility Locations Using Geographic Information System

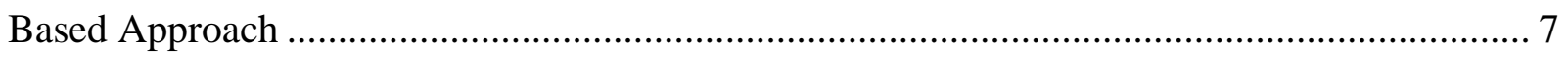

Task 2: Develop an Optimization Model for the Biofuel Supply Chain....................................... 9

Task 3: Develop a Simulation Model for the Biofuel Supply Chain ………………………….. 11

Task 4: Conduct Sensitivity Analysis to Evaluate the Impact of Different Parameters on

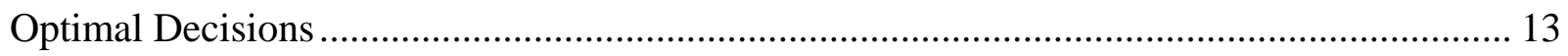

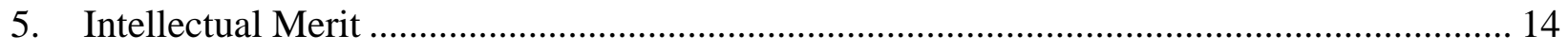

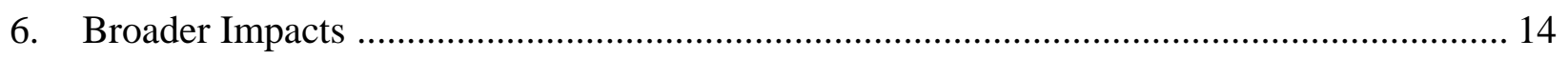

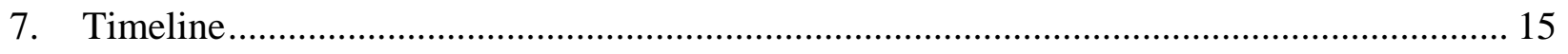

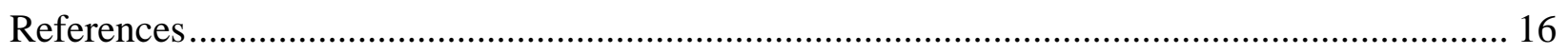

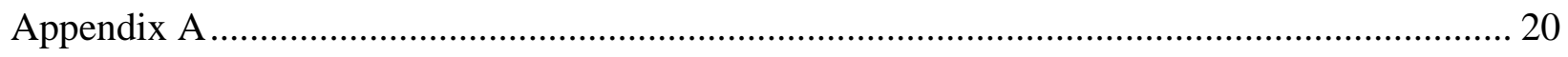

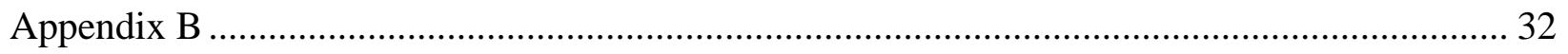

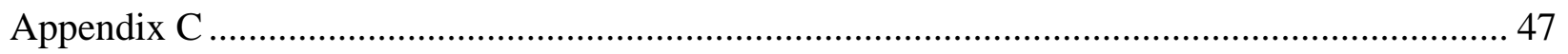

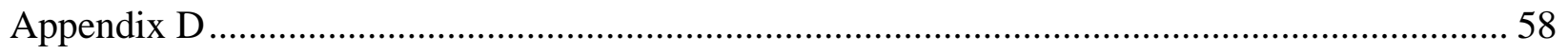




\section{Project Summary}

To mitigate greenhouse gas (GHG) emissions and reduce U.S. dependence on imported oil, the United States (U.S.) is pursuing several options to create biofuels from renewable woody biomass (hereafter referred to as "biomass"). Because of the distributed nature of biomass feedstock, the cost and complexity of biomass recovery operations has significant challenges that hinder increased biomass utilization for energy production. To facilitate the exploration of a wide variety of conditions that promise profitable biomass utilization and tapping unused forest residues, it is proposed to develop biofuel supply chain models based on optimization and simulation approaches. The biofuel supply chain is structured around four components: biofuel facility locations and sizes, biomass harvesting/forwarding, transportation, and storage. A Geographic Information System (GIS) based approach is proposed as a first step for selecting potential facility locations for biofuel production from forest biomass based on a set of evaluation criteria, such as accessibility to biomass, railway/road transportation network, water body and workforce. The development of optimization and simulation models is also proposed. The results of the models will be used to determine (1) the number, location, and size of the biofuel facilities, and (2) the amounts of biomass to be transported between the harvesting areas and the biofuel facilities over a 20-year timeframe. The multi-criteria objective is to minimize the weighted sum of the delivered feedstock cost, energy consumption, and GHG emissions simultaneously. Finally, a series of sensitivity analyses will be conducted to identify the sensitivity of the decisions, such as the optimal site selected for the biofuel facility, to changes in influential parameters, such as biomass availability and transportation fuel price.

\section{Intellectual Merit}

The proposed research will facilitate the exploration of a wide variety of conditions that promise profitable biomass utilization in the renewable biofuel industry. The GIS-based facility location analysis considers a series of factors which have not been considered simultaneously in previous research. Location analysis is critical to the financial success of producing biofuel. The modeling of woody biomass supply chains using both optimization and simulation, combing with the GISbased approach as a precursor, have not been done to date. The optimization and simulation models can help to ensure the economic and environmental viability and sustainability of the entire biofuel supply chain at both the strategic design level and the operational planning level.

\section{Broader Impacts}

The proposed models for biorefineries can be applied to other types of manufacturing or processing operations using biomass. This is because the biomass feedstock supply chain is similar, if not the same, for biorefineries, biomass fired or co-fired power plants, or torrefaction/pelletization operations. Additionally, the research results of this research will continue to be disseminated internationally through publications in journals, such as Biomass and Bioenergy, and Renewable Energy, and presentations at conferences, such as the 2011 Industrial Engineering Research Conference. For example, part of the research work related to biofuel facility identification has been published: Zhang, Johnson and Sutherland [2011] (see Appendix A). There will also be opportunities for the Michigan Tech campus community to learn about the research through the Sustainable Future Institute. 


\section{Introduction}

Oil consumption in the United States (U.S.) transportation sector contributes to a range of societal problems, including climate change, health related air pollution, the U.S. oil dependence and oil related national security concerns [1]. In 2009, the transportation sector consumed over $27 \%$ of total U.S. energy consumption and $72 \%$ of the nation's oil consumption [2]. The carbon emissions resulting from transportation fuel consumption were almost one-third of the U.S. total [1,3]. The Energy Information Administration (EIA) forecasted an annual growth in transportation energy consumption of 1.7\% between 1999 and 2020 [4]. If the projected growth rate holds, U.S. transportation energy and greenhouse gas (GHG) emissions will increase from current levels by $46 \%$ by 2020 [1]. The U.S. oil production peaked in 1970, and the U.S. is more dependent on foreign oil than at any time in history, importing 60\% of its supplies in 2006 [5].

Concerns rise from both general public and government officials over the perceived economic and security vulnerabilities resulting from the high level of U.S. dependence on foreign oil [5]. The U.S. is pursuing several options to create biofuels from renewable biomass and thus reduce dependence on imported fossil fuels and mitigate GHG emissions. Renewable biomass feedstock include agricultural residues, energy crops (e.g., switchgrass, miscanthus, energy cane, sorghum, polar, and willow), forest resources (e.g., forest thinnings, wood chips, wood wastes, small diameter trees), and urban wood wastes [6]. Using biochemical or thermo-chemical processes, renewable biomass can be converted to biofuels such as ethanol, methanol, diesel, gasoline, and methane [7]. Perlack et al. [8] suggest that 30\% of the present consumption of petroleum products can be displaced by biofuels in the U.S. by 2030. A joint biofuels systems analysis project, "90-Billion Gallon Biofuel Deployment Study," conducted by Sandia National Laboratories and the General Motors Research and Development Center, assessed the feasibility, implication, limitations, and enablers of large-scale production of biofuels in the U.S. [9]. This study concluded that producing 90 billion gallons (341 billion liters) of biofuels from biomass each year in the U.S. is feasible [10]. Sensitivity analysis also demonstrated that cellulosic biofuels can compete with petroleum products at a reasonable price based on specific assumptions [10].

Biofuels production from various lignocellulosic biomass types such as wood, agriculture residues and forest residues have the potential to be a valuable substitute for, or complement to, gasoline [11]. This research focuses on biofuel production from forest-based woody biomass feedstock, including forest residues and low value pulpwood, primarily used by paper mills. Ince and Durbak [12] stated that declining demand for pulpwood by the paper products industry has led to alternative uses for a readily available woody biomass feedstock. In the Southern U.S. (the major pulp producing area), pulpwood demand decreased by 7.5\% from 1994 to 2003 while the supply of pulpwood increased due to increased acreage and improved management intensity of pine plantations [13-14]. The USDA Forest Service forecasts that the U.S. demand for pulpwood will continue to decline in the next decade; this allows surplus pulpwood to be used for biofuel production [14].

One of the most important and challenging aspects of biofuel production is the design and operation of biomass supply chain networks [6]. The lack of experience with time-sensitive collection, transportation, and delivery operations to ensure year-round supply of large amounts of biomass feedstock is a barrier to widespread implementation of biorefinery technology [15]. 
To promote biofuel production from renewable biomass, several research questions need to be addressed and include: i) what is the optimal number, locations, and sizes of the biofuel facilities?, ii) what are the optimal suppliers for a biofuel facility and the amount of biomass they can supply over a specific period?, iii) how does the limited availability of biomass feedstock during the spring breakup period impact the supply chain?, iv) what is the optimal schedule for harvesting and delivering to ensure there is sufficient biomass available to be processed each day at a biofuel facility?, v) what is the minimum delivered cost, energy consumption and GHG emission for a biofuel facility of a particular size, using both total and average measure?, and vi) what decisions are influential in affecting the parameters, such as fuel price and biomass availability?

This research will investigate these research questions by applying a GIS model for the location selection of biofuel facilities. GIS can assist in location selection process through using spatial and statistical methods to analyze attribute and geographic information. The second phase will apply optimization and simulation techniques to the biofuel supply chain. The availability of such models will allow decision makers to design logistics that minimizes the total system cost, energy consumption and GHG emissions of biofuel. The next section elaborates on recent research on biofuels from biomass and how this research will address those gaps.

\section{Literature Review}

There is an extensive body of literature focusing on models and solutions that can be used as decision support tools for strategic analysis as well as tactical planning of biomass feedstock supply. As noted above, this decision support includes GIS to produce a comprehensive decision-making system [6]. The literature review provided below is based on a variety of articles/reports that were deemed to be relevant to this research. The articles/reports were chosen from two sources. In general, journal articles reviewed were chosen from database searches including keywords such as mathematical model, biomass supply chain, and cellulosic feedstock. Databases searched included but were not limited to Science Direct and Web of Knowledge. A series of reports developed by National Laboratories and governmental agencies (e.g., EIA) were reviewed either based on personal communication with them, or the focus area for the existing biofuel supply chain models.

\subsection{Facility location}

A variety of methodologies for facility location decision making were reviewed that have been presented in the technical literature. The focus was on traditional facility location analysis techniques, including basic quantitative methods and methods using both qualitative and quantitative criteria. Then, approaches that combine GIS systems with other models were evaluated. Lastly, GIS-based approaches that have been employed to address issues related to bioenergy facility locations were examined.

Facility location problems may be classified into two main categories: single facility location and multi-facility location [16]. One technique for making single facility location decisions is the Weber model, which employs a center-of-gravity approach for site selection, and was employed by Drezner and Wesolowsky [17] and Wesolowsky [18]. Various techniques for locating multiple facilities simultaneously were studied by Brimberg et al., such as alternative location- 
allocation, projection, Tabu search, p-median, genetic search, and different variable neighborhood searches [19]. Additional traditional facility location analysis techniques include location rating factor and load-distance [20].

Several basic quantitative methods for location selection have been applied in prior research and are relevant to this research study. These include mathematical modeling approaches such as data envelopment analysis modeling and binary integer linear programming model [21]. Approaches considering both qualitative and quantitative criteria for selecting the optimal location for a new facility were developed and applied, including Blin's fuzzy model, fuzzy synthetic evaluation, Yager's weighted goals method, and fuzzy analytic hierarchy process [22]. A hybrid method of selecting the best facility location considered critical factors for the first time, besides the commonly used objective and subjective factors [23]. The critical and subjective factors were defined from decision maker's judgments which are often linked to real world concerns [23]. However, these methods cannot handle spatial data. An important trend in location selection is using GIS-based techniques for making single- and multiple- facility location decisions. The advantage of using a GIS-based approach is that GIS is able to analyze both spatial and nonspatial data.

The integrated approaches of GIS and other quantitative and qualitative models, have been developed and applied in decision support systems for selecting locations, including a GIS-based simulated annealing algorithm for identifying waste disposal sites [24], an integrated approach of GIS and location-allocation model to identify the best location for public facility planning [24], GIS combined with expert knowledge to determine adequate potential soil aquifer treatment (SAT) sites for groundwater recharge of the Hammamet-Nabeul aquifer located in the 'Cap Bon' peninsula in north east Tunisia [26], an integrated approach of GIS technology and a landfill diagnosis method to assist in landfill sitting assessment [27], and an integrated model of GIS and fuzzy logic for taxicab stand location decisions [28]. The capability to handle spatial data with GIS was employed to analyze spatial associations between geothermal exploration and environmental evidence layers to determine the appropriate sites for exploratory wells in the Northwest Sabalan geothermal field [29]. In a word, the integrated approaches of GIS and other quantitative and qualitative models have proved to be an effective method in decision support systems for selecting locations.

With the growing interest in exploring renewable energy usage, GIS has proved to be an effective tool to address issues related to biomass availability and biomass logistics. Graham et al. [30] utilized GIS for a state-level modeling system to estimate regional geographic variations on delivered energy crop feedstock costs, and environmental impacts of switching from conventional crops to energy crops. Frombo et al. [31] introduced the GIS-based Environmental Decision Support System (EDSS) for strategic planning of optimal forest biomass logistics. Haddad and Anderson [32] identified potential supply locations of corn stover for bioenergy production by applying GIS. Voivontas et al. [33] estimated the biomass potential for power production from agriculture scraps based on GIS.

Certain features of GIS have been applied to address issues related to bioenergy facility locations. A proposed algorithm for generating a marginal price (or maximum delivered cost) surface was developed by Noon et al. [34] using a GIS-based analysis to identify potential ethanol conversion plant locations. The marginal price was composed primarily of transportation cost without considering farmgate price and competition for feedstock of nearby potential plants. 
Employing the marginal price surface approach for locating bioenergy facilities location, Panichelli and Gnansounou [35] considered site competition for biomass resources to develop a methodology for farmgate price calculation. A delivery cost surface based on GIS technology to compare two pricing strategies, fixed and discriminatory, was developed by Zhan et al. [36] to evaluate the economic variability of building a switchgrass-to-ethanol conversion facility in Alabama. Perpina et al. [37] applied GIS to analyze and identify optimal biomass logistics and transport strategies to locate bioenergy plants.

A GIS-based approach for identifying biofuel facility locations is proposed. The GIS analysis takes into account a series factors which have not been considered simultaneously in previous research. These factors include (a) county boundaries, (b) a railroad transportation network, (c) a state/federal road transportation network, (d) city and village distributions, (e) a population census, (f) a pulpwood production, (g) a water body (rivers, lakes, etc.), and (h) no co-location with any other competitors for biomass feedstock. The details will be described in the next couple of sections.

\subsection{Supply chain model}

Information from previously developed biomass supply chains formed the foundation for the development of the supply chain in this research. The National Biofuels Plan developed by the Biomass R\&D Board focuses on biomass feedstock processing and logistics that relate to the supply chain, such as harvesting process, storage facilities, and transportation of the feedstock [38]. The biofuel plan is based on the use of agricultural residues and woody residues as biomass feedstock [38]; for the present research, the supply chain is assumed to employ logs, which in the past were in demand by paper mills. The Idaho National Laboratory (INL) developed a uniformformat feedstock supply chain that can be implemented at a nationwide level [39-40]. The Sandia National Laboratories (SNL) developed a model that considers cellulosic ethanol from various biomass feedstock types, such as corn, agricultural residues, energy crops, and forest residues, to support the national goal of producing 90 billion gallons (341 billion liters) of biofuels each year in the U.S. by 2030 [41-42]. The Oak Ridge National Laboratory (ORNL) investigated the feasibility of expanding the ethanol industry, and specifically focused on the additional infrastructure that needs to be built [43].

Gronalt and Rauch [44] investigated the issue of centralized and decentralized chipping when designing a forest fuel network in order to meet the varying demands of each plant simultaneously using numerous storage facilities and terminals. Gunnarsson et al. [45] proposed a solution to the supply chain problem involving a forest fuel network structure through a large mixed integer linear programming (MILP) model. The fuels are forest residues from harvest areas or byproducts from sawmills, and are supplied to a combined heat and power (CHP) plant. De Mol et al. [46] created both simulation and optimization models for the network structure of biomass fuel collection. The network structure covers nodes including source locations, collection sites, transshipment sites, pre-treatment sites, and the energy plant. Road, water, and rail transportation modes are the three different choices to connect nodes [46]. McNeil Technologies, Inc. [47] investigated the feasibility of building a biomass-fuelled combined heat and power (CHP) plant in Jefferson County, Colorado. Several scenarios were considered including centralized and decentralized facilities, various conversion techniques, and different harvesting processes. Sokhansanj et al. [48] developed an integrated biomass supply analysis and logistics model (IBSAL) for supplying corn stover to a biorefinery through harvesting, storage, 
and transportation. The IBSAL model examines costs and optimum conditions for harvesting and transportation logistics of biomass material.

Huang et al. [49] proposed a mathematical model that integrates spatial and temporal dimensions for strategic planning of ethanol supply chain systems. This model incorporates dynamics issues in long-term strategic planning of biofuel systems, which was seldom considered in previous literature [49]. Eksioglu et al. [50] developed a mathematical model to design biomass-tobiorefinery supply chain and manage the logistics of a biorefinery. This model took an integrated view of biomass harvesting, inventory, transportation processes and biorefinery location. Parker et al. [51] built an integrated model based on GIS and mathematical programming to evaluate the economic potential and infrastructure requirements of hydrogen production from agricultural residues. Rentizelas et al. [52] built and optimized a multi-biomass supply chain model for trigeneration energy (electricity, heating and cooling) production to maximize the financial yield of the investment for investors. Luo et al. [53] proposed a detailed technical design combining with economic and environmental analysis of a lignocellulosic feedstock (LCF) biorefinery producing ethanol, power and high-value chemicals (succinic acid and acetic acid).

A new analytical tool that integrates cost, energy savings, GHG considerations, scenario analysis and a Geographic Information System was developed to provide a comprehensive analysis of alternative systems for optimizing biomass energy production [54]. A two-stage mixed integer mathematical model was developed to optimize biomass supply chain networks under uncertainty, such as supply amounts, market demand, market price, and processing technologies [55]. The logistics of supplying forest biomass to a potential power plant was investigated using a simulation model which was developed by extending the Integrated Biomass Supply Analysis and Logistics (IBSAL) model [56].The simulation model evaluated the delivered feedstock cost, the equilibrium moisture content, and carbon emission from the logistic operations [56]. A MILP model was created to optimize ethanol supply chain configuration in terms of profitability and financial risk on investment [57]. The biofuel supply chain covers from the upstream fuel production, such as biomass cultivation, biomass delivery, and fuel production, to the downstream, such as biofuel distribution to demand centers [57].

The strategic design and planning of corn grain- and stover-based bioethanol supply chains through first and second generation technologies were addressed [58]. A MILP model was created to optimize the environmental (in terms of overall GHG emissions) and financial (Net Present Value, NPV) performances simultaneously [58]. A MILP model was developed to optimize a biomass-to-ethanol supply chain in terms of net present value in a 9-state region in the Midwestern United States [59]. Perimenis et al. proposed the basic framework for a decision support tool to evaluate biofuel production pathways from biomass production to biofuel end-use [60]. The tool integrates the technical, economic, environmental and social aspect with a goal of identifying an alternative solution that optimizes all the criteria [60].

A mixed integer-linear optimization model was developed and implemented to assess potential biofuel supply across the Western United States from agricultural, forest, urban, and energy crop biomass [61]. The model is to determine the optimal locations, technology types and sizes of biorefineries to satisfy a maximum profit objective function applied across the biofuel supply and demand chain from site of feedstock production to the product fuel terminal [61]. The technology types and biofuel demand chain are beyond the scope of the present study. A MIPL model, named BioFeed, was developed focusing on the feedstock production and provision 
activities between farms growing energy crops and the biorefinery, such as harvesting, raking, baling, storage, handling and transportation [62]. A MIPL model was formulated and implemented to determine (1) the number, location, and size of the two types of processing facilities, and (2) the amounts of biomass, intermediate products, and final products to be transported between the selected locations over a selected period [63]. A combined life cycle analysis and supply chain optimization approach was proposed to access the economic and environmental sustainability of ethanol production systems [64]. The objective functions are to maximize the net present value and to minimize the total daily GHG impact associated [64].

The comparison description in previous paragraphs summarizes previous studies on design of biofuel supply chain. There is limited work in the area of modeling woody biomass supply chains as it has primarily focused on other forms of biomass and/or used only optimization or simulation but not both simultaneously. Exploring the potential utilization of low value pulpwood, which was primarily used by paper mills, as biomass feedstock for biofuel production has never been done. Additionally as a precursor to optimization or simulation modeling, GIS have been used as a determinant of specific multiple locations. All three methodologies used together have not been done to date. In addition, evaluating the influence of spring breakup, which is exclusive to northern climates with snow and ice, on the biofuel supply chain has not been addressed. Since roads are restricted during spring breakup period, there is a need to have additional inventory on hand at the biofuel facility. Not properly addressing this issue, including efforts to build up and store inventory, will either lead to plant shutdown or produce increased total system cost due to the need of securing biomass from prohibitively expensive sources.

\section{Research Objective}

To promote biofuel production from renewable biomass, several research questions need to be addressed and include: i) what is the optimal number, locations, and sizes of the biofuel facilities?, ii) what are the optimal suppliers for a biofuel facility and the amount of biomass they can supply over a specific period?, iii) how does the limited availability of biomass feedstock during the spring breakup period impact the supply chain?, iv) what is the optimal schedule for harvesting and delivering to ensure there is sufficient biomass available to be processed each day at a biofuel facility?, v) what is the minimum delivered cost, energy consumption and GHG emission for a biofuel facility of a particular size, using both total and average measure?, and vi) what decisions are influential in affecting the parameters, such as fuel price and biomass availability? With this in mind, the following research objective is proposed:

\section{Development of an Optimization Model for Biofuel Facility Size and Location and a Simulation Model for Design of a Biofuel Supply Chain}

\section{Task 1: Identify Candidate Biofuel Facility Locations Using Geographic Information System Based Approach}

A GIS-based approach has been proposed to preselect several candidate locations for biofuel production based on a set of evaluation criteria, such as accessibility to biomass, railway/road transportation network, water resource (e.g., rivers and lakes), and trainable workforce. 


\section{Task 2: Develop an Optimization Model for the Biofuel Supply Chain}

The optimization model and supporting information will be developed after candidates for the biofuel facility location have been identified. The optimization model will be used to determine (1) the optimal number, locations, and sizes of the biofuel facilities, and (2) the amounts of biomass to be transported between the harvesting areas and the biofuel facilities over a selected period, and minimize the objective function that considers the delivered feedstock cost, energy consumption and GHG emissions simultaneously.

\section{Task 3: Develop a Simulation Model for the Biofuel Supply Chain}

Compared with the optimization model, the simulation model provides a more refined, complex, and dynamic understanding of the 20-year operation of the biomass-to-biofuel system. The simulation model will be used to examine strategies that ensure availability of biomass feedstock during the spring breakup period. The simulation model will also be used to evaluate the suitable schedule for harvesting and delivering to ensure there is sufficient biomass available to be processed each day at a biofuel facility. The objectives will be to minimize delivered cost, energy consumption and GHG emission for a biofuel facility of a particular size, using both total and average measure.

\section{Task 4: Conduct Sensitivity Analysis to Evaluate the Impact of Different Parameters on Optimal Decisions}

A series of analyses will be conducted to understand the sensitivity of the decisions (e.g., the optimal site selected for the biofuel facility), to changes in influential parameters, including biomass availability and transportation fuel price.

The following section will describe these tasks in detail.

\section{Task Descriptions}

Task 1: Identify Candidate Biofuel Facility Locations Using Geographic Information System Based Approach

"To implement cost-effective biofuel production, the selection of the best location for a processing facility becomes a critical concern. This is because biomass feedstock is geographically dispersed, and the location of a biofuel facility significantly influences transportation costs. A GIS based approach is proposed for selecting potential facility locations for biofuel production from forest biomass based on a set of evaluation criteria. The GIS analysis takes into account the following factors: (a) county boundaries, (b) a railroad transportation network, (c) a state/federal road transportation network, (d) city and village distributions, (e) a population census, and (f) a pulpwood production” [65] (p. 3952, see Appendix A). This method is extended by considering other two factors (g) a water body (rivers, lakes, etc.), and (h) no colocation with any other competitors for biomass feedstock.

“The GIS-based approach was applied to the Lower Peninsula of Michigan (the L.P.) and nine potential biofuel facility locations were selected. The names of the nine potential sites as well as the distance (miles) to the closest co-fired power plant, is shown in Table 1 . The map in Figure 1 
shows the distribution of the nine potential sites” [66] (p. 10-11).

Table 1 Potential Site for Biorefinery in the L.P., Michigan

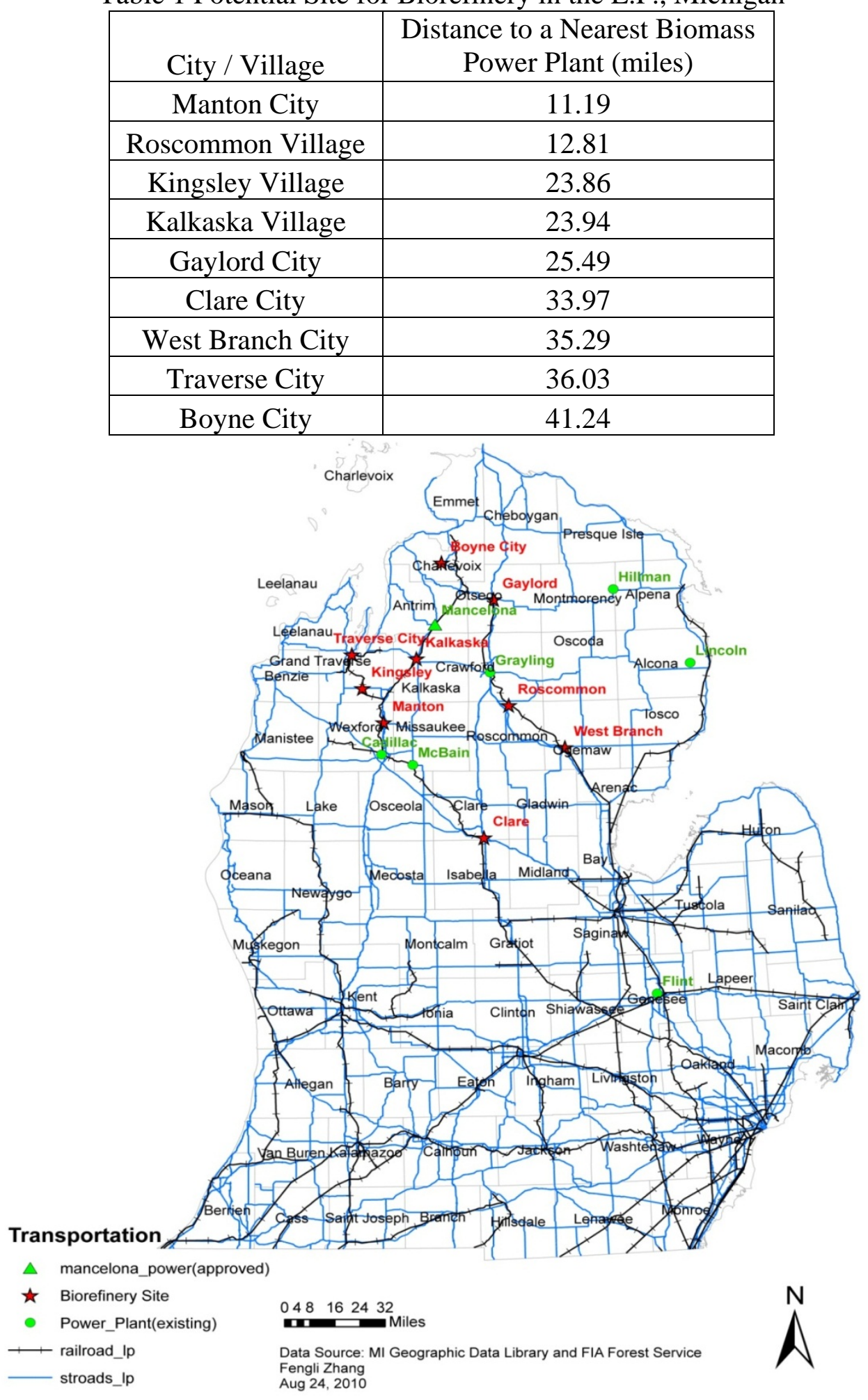

Figure 1 Nine Potential Biofuel Facility Locations in the L.P., Michigan 
The potential harvesting areas (biomass feedstock suppliers) for each candidate location within its 100-mile radius were also identified using GIS analysis. Figure 2 shows the distribution of the potential harvesting areas for the Gaylord City.

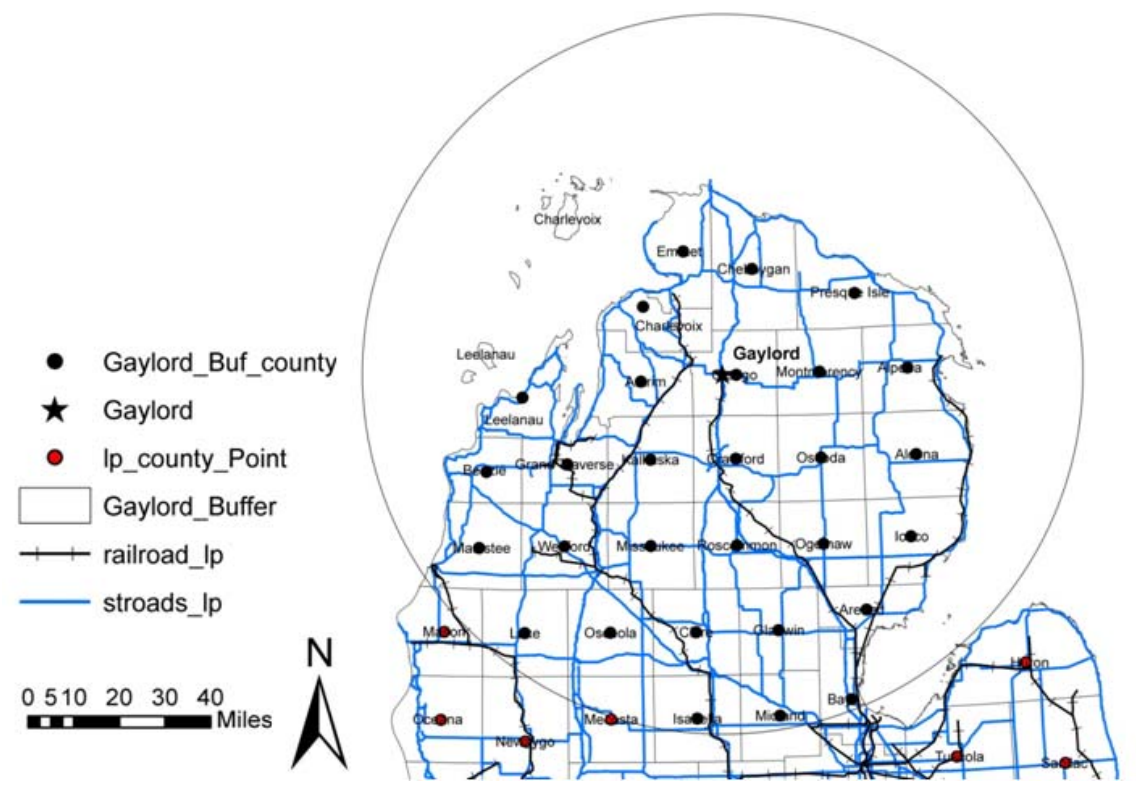

Figure 2 Potential Harvesting Areas for the Gaylord Facility within 100-Mile Radius

\section{Task 2: Develop an Optimization Model for the Biofuel Supply Chain}

The biofuel supply chain is structured around four components: biofuel facility locations and sizes, biomass harvesting/forwarding, transportation, and storage. An optimization model is proposed to enable the selection of biomass locations, biorefinery capacities, and the logistics of transportation from biomass locations to the biorefineries. A mixed integer linear programming (MILP) model will be formulated and implemented in a software package (mathematical programming language, MPL) using databases built in Excel. The MILP will represent decisions regarding (1) the optimal number, locations, and sizes of the biofuel facilities, and (2) the amounts of biomass to be transported between the harvesting areas and the biofuel facilities over a selected period, and minimize the objective function of the delivered feedstock cost, energy consumption and GHG emissions simultaneously.

\section{Mathematical model}

\section{Indices}

- I Set of harvesting sites, indexed by i

- $\mathrm{J}$ Set of potential locations for biorefinery, indexed by $\mathrm{j}$

\section{Model Inputs}

- $\mathrm{c}_{\mathrm{ij}}$ Unit cost (\$/ton) of biomass, including stumpage price, harvesting/forwarding cost, and transportation cost

- $\mathrm{e}_{\mathrm{ij}}$ Unit energy consumption (1000 Btu/ton), associated with harvesting/forwarding and transportation

- $g_{\mathrm{ij}}$ Unit GHG emissions (lb/ton), associated with harvesting/forwarding and transportation 
- $b_{i}$ Biomass availability (ton) at harvesting site i

- $\mathrm{r}$ Conversion rate (gallons biofuel /green ton of biomass)

- D Total biofuel demand (MGY) per year

- $\mathrm{w}_{\mathrm{c}}$ Weight (\%) of cost

- $\mathrm{w}_{\mathrm{e}}$ Weight (\%) of energy consumption

- $\mathrm{w}_{\mathrm{g}}$ Weight (\%) of GHG emissions

\section{Decision Variables}

- $\mathrm{q}_{\mathrm{ij}}$ Amount (ton) of biomass at harvesting site i shipped to biofuel facility $\mathrm{j}$

- $\varphi_{\mathrm{j}}$ Equals to 1 if a biorefinery is built at site $\mathrm{j}$, and 0 otherwise

- $s_{j}$ Size (MGY) of a biofuel facility, if any, to be built at site $j$

\section{Objective Function}

The objective is to minimize the biofuel supply chain system "cost” (C) that is the weighted sum of the delivered feedstock costs, energy consumption and GHG emissions.

$$
\mathrm{C}=\sum_{\mathrm{i}=1}^{\mathrm{I}} \sum_{\mathrm{j}=1}^{\mathrm{J}}\left(\mathrm{c}_{\mathrm{ij}} \cdot \mathrm{w}_{\mathrm{c}}+\mathrm{e}_{\mathrm{ij}} \cdot \mathrm{w}_{\mathrm{e}}+\mathrm{g}_{\mathrm{ij}} \cdot \mathrm{w}_{\mathrm{g}}\right) \cdot \mathrm{q}_{\mathrm{ij}}
$$

\section{Constraints/Limitations}

- Constraint at harvesting site

- The delivered amount of each biomass cannot exceed its corresponding maximum availability at harvesting area $\mathrm{i}$

$$
\sum_{j=1}^{J} q_{i j} \leq b_{i} \quad \forall i
$$

- Constraints at biorefinery

- The demand for biomass of a biorefinery at location $\mathrm{j}$ equals supply.

$$
\sum_{\mathrm{i}=1}^{\mathrm{I}} \mathrm{q}_{\mathrm{ij}}=1000000 \cdot \mathrm{s}_{\mathrm{j}} / \mathrm{r} \quad \forall \mathrm{j}
$$

- The biofuel production meets the biofuel demand per year

$$
\sum_{j=1}^{J} s_{j}=D
$$

- Set up the lower and upper bounds of facility size

$$
30 \cdot \varphi_{j} \leq s_{j} \leq 50 \cdot \varphi_{j} \quad \forall \mathrm{j}
$$

- Nonnegative constraint

- Amount (tons) of biomass transported from harvesting area i to biorefinery $\mathrm{j}$ is nonnegative

$$
\mathrm{q}_{\mathrm{ij}} \geq 0 \quad \forall \mathrm{i}, \forall \mathrm{j}
$$

- Binary constraint

$$
\varphi_{j} \in(0,1) \quad \forall \mathrm{j}
$$


The MPL model was run by changing the demand for biofuel from 50 MGY per year to 300 MGY per year in increments of 50 MGY to examine the sensitivity of decisions on demand. The results are shown in Table 2.

Table 2 MPL Results of Facility Size at Each Location

\begin{tabular}{|c|c|c|c|c|c|c|c|c|c|}
\hline \multicolumn{9}{|c|}{ Facility Size (MGY) at Each Location } & \multirow{2}{*}{$\begin{array}{c}\text { Total } \\
\text { Demand } \\
(\mathrm{MGY})\end{array}$} \\
\hline Manton & Roscommon & Kingsley & Kalkaska & Gaylord & Clare & $\begin{array}{l}\text { West } \\
\text { Branch }\end{array}$ & $\begin{array}{l}\text { Traverse } \\
\text { City }\end{array}$ & $\begin{array}{l}\text { Boyne } \\
\text { City }\end{array}$ & \\
\hline 0.00 & 0.00 & 0.00 & 0.00 & 50.00 & 0.00 & 0.00 & 0.00 & 0.00 & 50.00 \\
\hline 34.75 & 0.00 & 0.00 & 0.00 & 30.00 & 0.00 & 35.25 & 0.00 & 00 & 100.00 \\
\hline 30.00 & 0.00 & 0.00 & 30.00 & 30.00 & 30.00 & 30.00 & 0.00 & 0.00 & 150.00 \\
\hline 30.00 & 0.00 & 30.00 & 0.00 & 30.00 & 35.24 & 44.76 & 0.00 & 30.00 & 200.00 \\
\hline 46.88 & 30.00 & 30.00 & 0.00 & 30.00 & 50.00 & 33.12 & 0.00 & 30.00 & 250.00 \\
\hline 50.00 & 39.47 & 50.00 & 0.00 & 30.53 & 50.00 & 50.00 & 0.00 & 30.00 & 300.00 \\
\hline
\end{tabular}

An Excel-based optimization model with a user friendly input screen has been developed for the Forestry Biofuel Statewide Collaboration Center (FBSCC). "Due to the Excel Solver size limitations regarding the number of changing cells and number of decisions, the model focused on single location and three multi-location configurations over a single time period (one year). For the single location models, cost, emissions, and energy were minimized to optimize the individual attributes. In the case of the multi-location configurations, only cost was evaluated. The model also allows for sensitivity analysis by changing inputs to evaluate different scenarios. The underlying model is a linear optimization model based on transportation networks” [66] (p. 30).

\section{Task 3: Develop a Simulation Model for the Biofuel Supply Chain}

In this task, a biofuel supply chain simulation model will be built around biomass harvesting/forwarding, transportation and storage, and will be evaluated using multiple criteria including the delivered feedstock cost, energy consumption, and GHG emissions. Compared with the optimization model, the simulation model provides a more refined, complex, and dynamic understanding of the 20-year operation of the biomass-to-biofuel system. The simulation model is develop to: i) address the limited availability of biomass feedstock during the spring breakup period, ii) find the suitable schedule for harvesting and delivering to ensure there is sufficient biomass available to be processed each day at a biofuel facility, and iii) calculate the minimum delivered cost, energy consumption and GHG emission for a biofuel facility of a particular size, using both total and average measure.

"The simulation model will be built using Arena Simulation Software [67]. The model consists of three sub-models: reading model inputs, supply activities, and daily biomass processing (Figure 3). Sub-models communicate with each other via signals. Two types of signals are created: transportation signals (the solid arrows in Figure 3) and reading data signals (the open arrow in Figure 3). Transportation signals can either come from the sub-model of "reading model inputs" or the daily biomass processing sub-model. "Reading data signals" are created by the supply sub-model and sent to the reading model inputs sub-model” [66] (p. 46). 


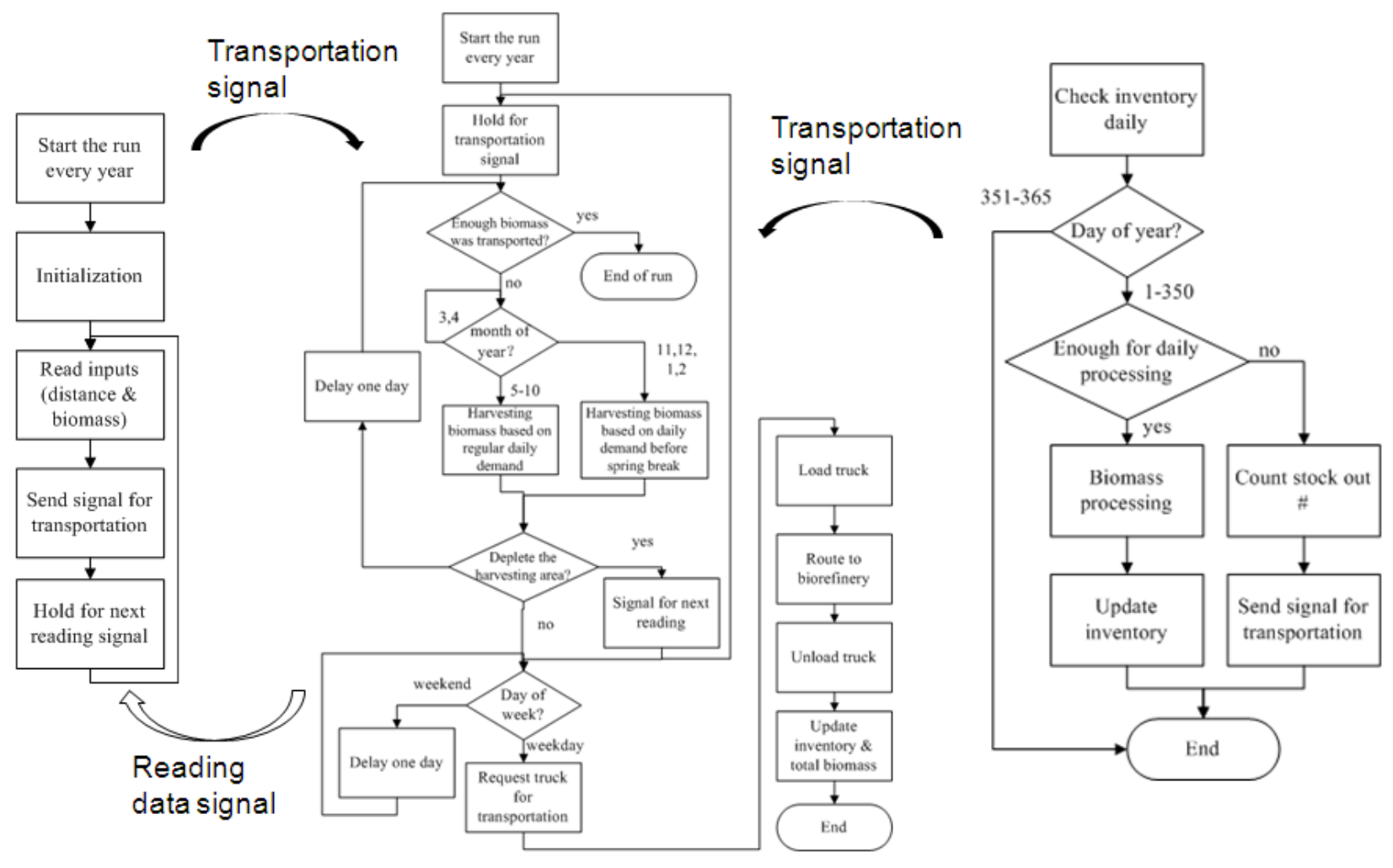

Figure 3 Simulation Model Logic

The utility of the simulation model may be demonstrated by considering the location of a biofuel facility in the L.P. of Michigan. Nine potential biofuel facility sites in the L.P. were preselected by employing the GIS-based method described in Task 1. One simulation was run for a biofuel facility of $50 \mathrm{MGY}$ in the city of Gaylord, Michigan. "The start date for the simulation was set as Nov 1st, 2011 and the model run length was 350 days a year, 20 years in total. The time step during the simulation was set as one day. The inventory (tons) changes as a function of time following the pattern demonstrated in Figure 4. Table 3 shows the eight most preferable harvesting areas (ordered by the distance from a harvesting area to the facility) for supplying the Gaylord plant” [66] (p. 55). 


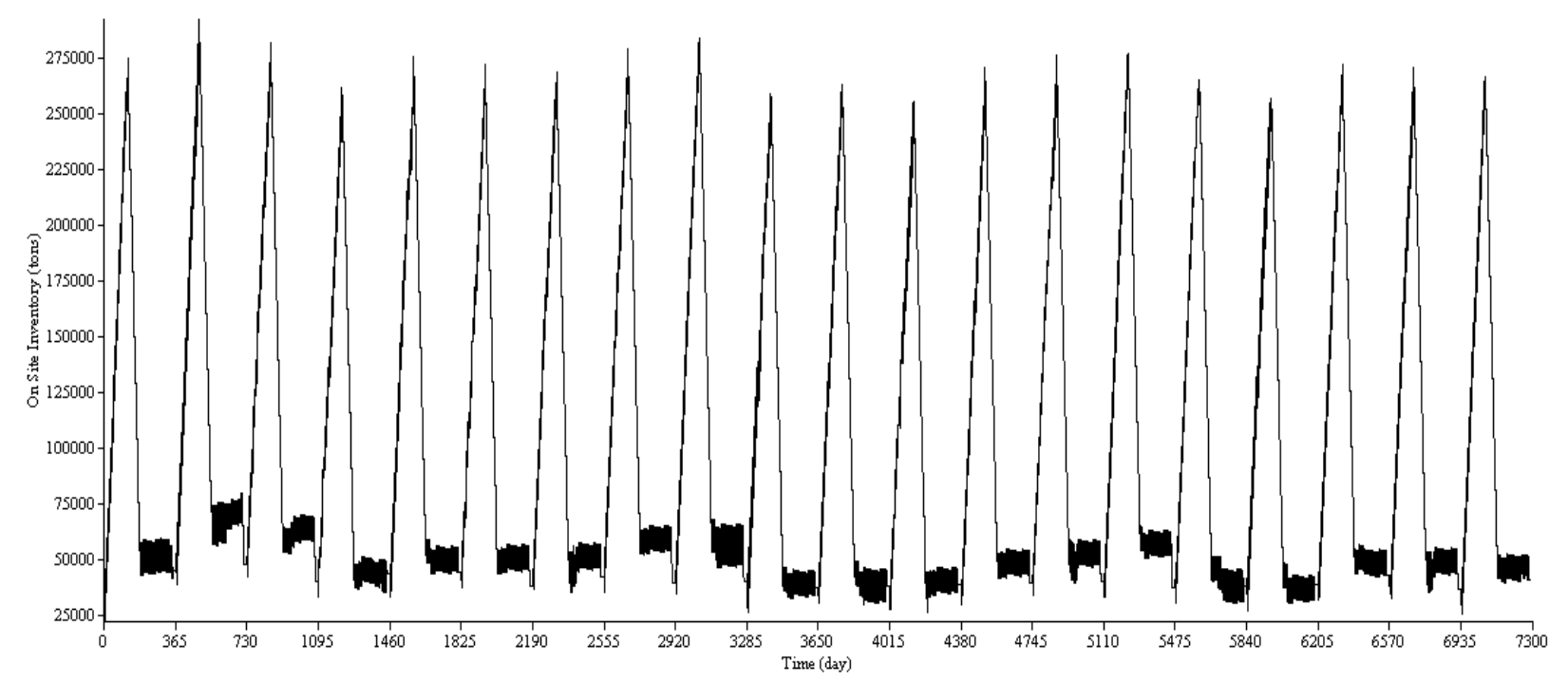

Figure 4 Inventory Level for a Facility Size of 50 MGY in Gaylord Operating 20 Years

Table 3 Eight Optimal Harvesting Areas for Supplying Gaylord Plant

\begin{tabular}{|c|c|c|c|}
\hline Order & $\begin{array}{c}\text { Harvesting } \\
\text { Area }\end{array}$ & $\begin{array}{c}\text { Rectilinear } \\
\text { Distance (mile) }\end{array}$ & $\begin{array}{c}\text { Biomass } \\
\text { (green tons) }\end{array}$ \\
\hline 1 & Otsego & 4.023 & 274,920 \\
\hline 2 & Antrim & 24.754 & 134,827 \\
\hline 3 & Crawford & 27.196 & 120,789 \\
\hline 4 & Montmorency & 27.607 & 200,041 \\
\hline 5 & Cheboygan & 37.356 & 225,280 \\
\hline 6 & Charlevoix & 40.748 & 96,751 \\
\hline 7 & Kalkaska & 43.740 & 171,816 \\
\hline 8 & Emmet & 44.968 & 28,450 \\
\hline
\end{tabular}

Multiple simulation runs have been made for different facility size of $30 \mathrm{MGY}, 40 \mathrm{MGY}$, and 50 MGY and different biofuel facility locations. The results are consistent with the Excel-based optimization model.

\section{Task 4: Conduct Sensitivity Analysis to Evaluate the Impact of Different Parameters on Optimal Decisions}

"The foregoing analysis made a number of assumptions, such as biomass availability, transportation fuel price, and biomass conversion rate. With this in mind, a series of analyses will be conducted to identify the sensitivity of the decisions, such as the optimal site selected for the biofuel facility, to influential parameters. This sensitivity analysis will consider parameters including biomass availability and fuel price. For investigating the sensitivity to changes in fuel price and biomass availability, deviations from the base case will be considered” [65] (p. 3957).

Fuel price will have an impact on transportation cost. In order to evaluate the effect of fuel price on the cost, the alternative fuel prices shown in Table 4 will be evaluated. The prices considered were i) the average fuel price for 2009 (2009 Avg.), ii) the highest price for 2009 (2009 Max.), iii) 
the lowest price for 2009 (2009 Min.), and iv) the highest price for the five years between 2007 and 2011 (5 Yr. Max) [68].

Table 4 The Alternative Fuel Prices

\begin{tabular}{|c|c|c|}
\hline Date & Diesel Fuel (\$/L) & Diesel Fuel (\$/gal) \\
\hline Sept 2011 Avg. & 1.014 & 3.840 \\
\hline 2009 Avg. & 0.651 & 2.464 \\
\hline 2009 Min. & 0.553 & 2.092 \\
\hline 2009 Max. & 0.738 & 2.792 \\
\hline 5 Yr. Max & 1.242 & 4.703 \\
\hline
\end{tabular}

"In the base case study, the amount of biomass that could be sustainably harvested annually was taken directly from the net forest growth. It is likely that not all biomass will be available for a biofuel facility because of other competing uses for the same biomass. Competitors for biomass may come from paper mills, co-fired power plants, and other existing bioenergy facilities. To consider situations where less than $100 \%$ of the low value pulpwood and forest residues is available for biofuel production, several other biomass availability percentages will be considered: from $50 \%$ to $100 \%$ in increments of 10\%” [65] (p. 3959). This parameter may expect the selection of the optimal biofuel facility location decision and other operational level decisions, such as the amount of biomass harvested per day on each harvesting area.

\section{Intellectual Merit}

The proposed research will facilitate the exploration of a wide variety of conditions that promise profitable biomass utilization in the renewable biofuel industry. The GIS-based facility location analysis considers a series of factors which have not been considered simultaneously in previous research. Location analysis is critical to the financial success of producing biofuel. The modeling of woody biomass supply chains using both optimization and simulation, combing with the GISbased approach as a precursor, have not been done to date. The optimization and simulation models can help to ensure the economic and environmental viability and sustainability of the entire biofuel supply chain at both the strategic design level and the operational planning level.

\section{Broader Impacts}

The proposed models for biorefineries can be applied to other types of plants. This is because the biomass feedstock supply chain is similar, if not the same, for biorefineries, biomass fired or cofired power plants, or torrefaction/pelletization operations. Additionally, the research results of this research will continue to be disseminated internationally through publications in journals, such as Biomass and Bioenergy, and Renewable Energy, and presentations at conferences, such as the 2011 Industrial Engineering Research Conference. For example, part of the research work related to biofuel facility identification has been published: Zhang, Johnson and Sutherland [2011] (see Appendix A). There will also be opportunities for Michigan Tech campus community to learn about the research through the Sustainable Future Institute. 


\section{Timeline}

The tasks associated with the proposed research will be completed according to the timeline shown in Table 5.

Table 5 Timeline for Completion of Tasks

\begin{tabular}{|c|c|c|c|c|c|c|c|c|c|}
\hline \multirow[b]{2}{*}{ Task } & \multicolumn{4}{|c|}{2011} & \multicolumn{5}{|c|}{2012} \\
\hline & Sept & Oct & Nov & Dec & Jan & Feb & Mar & Apr & May \\
\hline $\begin{array}{l}\text { Task 1: Identify Candidate Biofuel Facility Locations } \\
\text { Using Geographic Information System based Approach }\end{array}$ & \multicolumn{9}{|c|}{ Completed } \\
\hline \multirow{2}{*}{$\begin{array}{l}\text { Task 2: Develop an Optimization Model for the } \\
\text { Biofuel Supply Chain }\end{array}$} & \multicolumn{9}{|c|}{ Excel-based model completed } \\
\hline & $\begin{array}{c}\text { Literature } \\
\text { review }\end{array}$ & $\begin{array}{r}\text { Pro } \\
\text { MPL }\end{array}$ & $\begin{array}{l}\text { gram } \\
\text { model }\end{array}$ & $\begin{array}{r}\text { Refi } \\
\text { mo }\end{array}$ & $\begin{array}{l}\text { e the } \\
\text { lel }\end{array}$ & $\begin{array}{l}\text { Manu } \\
\text { Prepa }\end{array}$ & $\begin{array}{l}\text { script } \\
\text { ration }\end{array}$ & & \\
\hline $\begin{array}{l}\text { Task 3: Develop a Simulation Model for the Biofuel } \\
\text { Supply Chain }\end{array}$ & \begin{tabular}{|c} 
Literature \\
review
\end{tabular} & & Refine & e mod & & $\begin{array}{l}\text { Manu } \\
\text { Prepa }\end{array}$ & $\begin{array}{l}\text { script } \\
\text { ration }\end{array}$ & & \\
\hline $\begin{array}{l}\text { Task 4: Conduct Sensitivity Analysis to Evaluate the } \\
\text { Impact of Different Parameters on Optimal Decisions }\end{array}$ & \multicolumn{3}{|c|}{ Literature review } & \multicolumn{3}{|c|}{$\begin{array}{l}\text { Conduct sensitivity } \\
\text { analysis }\end{array}$} & \multicolumn{3}{|c|}{$\begin{array}{l}\text { Manuscript } \\
\text { Preparation }\end{array}$} \\
\hline
\end{tabular}




\section{References}

[1] Greene D.L. and Plotkin S.E., Energy futures for the US transport sector. Energy Policy 2011;29:1255-1270.

[2] U.S. Energy Information Administration. Annual Energy Review 2009. Available at www.eia.gov/aer. 2010.

[3] Davis, S.C., Transportation Energy Data Book, 20th Edition. ORNL-6959, Oak Ridge National Laboratory, Oak Ridge, Tennessee. 2000.

[4] US Department of Energy, Energy Information Administration (US DOE/EIA), Annual Energy Outlook 1999, DOE/EIA-0383, Washington, DC. 1999.

[5] Gallagher K.S., Collantes G., Holdren J.P., Lee H., and Frosch R., Policy Options for Reducing Oil Consumption and Greenhouse-Gas Emissions from the U.S. Transportation Sector. July 2007. Available at:http://environment.harvard.edu/docs/faculty_pubs/lee_policy.pdf.

[6] Kim J., Realff M.J., Lee J.H., Whittaker C., and Furtner L., Design of biomass processing network for biofuel production using an MIPL model. Biomass and Bioenergy 2011;35:853-871.

[7] U.S. Environmental Protection Agency: Energy, Biofuels \& Climate Change. Available at: http://www.epa.gov/Sustainability/energy.htm.

[8] Perlack R.D., Wright L.L., Turhollow A.F., Graham R.L., Stokes B.J., Erbach D.C., Biomass as Feedstock for a Bioenergy and Bioproducts Industry: The Technical Feasibility of a Billion-Ton Annual Supply. Oak Ridge National Laboratory, ORNL/TM2005/66. Available at: http://feedstockreview.ornl.gov/pdf/billion_ton_vision.pdf; 2005 [accessed 02.08.2009].

[9] Sandia National Laboratories (SNL), General Motors’ R\&D Center. 90-Billion Gallon Biofuel Deployment Study: Executive Summary. Available at: http://www.greenbiz.com/sites/default/files/document/Exec_Summary02-2009.pdf; 2009 [accessed 02.09.2009].

[10] West T., Dunphy-Guzman K., Sun A., Malczynski L., Reichmuth D., Larson R., Ellison J., Taylor R., Tidwell V., Klebanoff L., Hough P., Lutz A., Shaddix C., Brinkman N., Wheeler C., and O’Toole D., Feasibility, economics, and environmental impact of producing 90 billion gallons of ethanol per year by 2030. Available at: http://www.sandia.gov/news/publications/white-papers/90-Billion-GallonBiofuelSAND2009-3076J.pdf; 2009 [preprint, accessed 02.09.2009].

[11] Kumar P., Barrett D.M., Delwiche M.J., and Stroeve P., Methods for Pretreatment of Lignocellulosic Biomass for Efficient Hydrolysis and Biofuel Production. Ind. Eng. Chem. Res. 2009;48:3713-3729.

[12] Ince P.J., and Durbak I., Pulpwood Supply and Demand Development in the South, Little Growth Elsewhere. J Forest 2002;100(2):20-25.

[13] Leightley L.E., Testimony before the Subcommittee on Forests and Forest Health, Committee on Resources, U.S. House of Representatives. Available at:

http://republicans.resourcescommittee.house.gov/UploadedFiles/testimony/2006/liamleig htleyHTM.pdf; 2006 [accessed 02.09.2009].

[14] Walsh M., U.S. Cellulosic Biomass Feedstock Supplies and Distribution, M\&E Biomass Publication. Available at:

http://ageconsearch.umn.edu/bitstream/7625/2/U.S.\%20Biomass\%20Supplies.pdf; 2008 
[accessed 02.09.2009].

[15] Sokhansanj S., Feedstock Supply Technologies: Essential Support for Biobased Industries, Bioenergy Feedstock Program, Oak Ridge National Laboratory, 2000.

[16] Esnaf S., and Küçükdeniz T., A fuzzy clustering-based hybrid method for a multi-facility location problem. J Intell Manuf 2009;20:259-265.

[17] Drezner Z., and Wesolowsky G.O., The Expected Value of Perfect Information in Facility Location. Oper Res1980;28(2):395-402.

[18] Wesolowsky G.O., Probabilistic Weights in the One-Dimensional Facility Location Problem. Manage Sci 1977;24(2):224-229.

[19] Brimberg J., Hansen P., Mladenovic N., and Taillard E.D., Improvement and Comparison of Heuristics for Solving the Uncapacitated Multisource Weber Problem. Oper Res 2000;48(3):444-460.

[20] Krajewski L.J., Ritzman L.P., and Malhotra M.K., Operations Management (Ninth Edition). Pearson Education, Inc. 2009.

[21] Cheng E.W.L., and Li H., Exploring quantitative methods for project location selection, Build Environ 2004;39(12):1467-1476.

[22] Kahraman C., Ruan D., and Dogan I., Fuzzy group decision-making for facility location selection. Inform Sciences 2003;157:135-153.

[23] Tabari M., Kaboli A., Aryanezhad M.B., Shahanaghi K., and Siadat A., A new method for location selection: A hybrid analysis. Appl Math Comput 2008;206:598-606.

[24] Muttiah R.S., Engel B.A., and Jones D.D., Waste disposal site selection using GIS-based simulated annealing. Comput Geosci1996;22:1013-1017.

[25] Yeh A.G.-O., and Chow M.H., An integrated GIS and location-allocation approach to public facilities planning--An example of open space planning. Comput Environ Urban1996;20:339-350.

[26] Kallali H., Anane M., Jellali S., and Tarhouni J., GIS-based multi-criteria analysis for potential wastewater aquifer recharge sites. Desalination 2007;215:111-119.

[27] Zamorano M., Molero E., Hurtado Á., Grindlay A., and Ramos Á., Evaluation of a municipal landfill site in Southern Spain with GIS-aided methodology.J Hazard Mater 2008;160:473-481.

[28] Ocalir E.V., Ercoskun O.Y., and Tur R., An integrated model of GIS and fuzzy logic (FMOTS) for location decisions of taxicab stands. Expert Syst Appl 2010;37:4892-4901.

[29] Noorollahi Y., Itoi R., Fujii H., and Tanaka T., GIS integration model for geothermal exploration and well siting. Geothermics 2008;37:107-131.

[30] Graham R.L., English B.C., and Noon C.E., A Geographic Information System-based modeling system for evaluating the cost of delivered energy crop feedstock. Biomass Bioenerg 2000;18(4):309-329.

[31] Frombo F., Minciardi R., Robba M., Rosso F., and Sacile R., Planning forest biomass logistics for energy production: A strategic decision model. Biomass Bioenerg 2009;33(3):372-383.

[32] Haddad M.A., and Anderson P.F., A GIS methodology to identify potential corn stover collection locations. Biomass Bioenerg 2008;32(12):1097-1108.

[33] Voivontas D., Assimacopoulos D., and Koukios E.G., Assessment of biomass potential for power production: a GIS based method. Biomass Bioenerg 2001;20(2):101-112.

[34] Noon C.E., Zhan F.B., and Graham R.L., GIS-Based Analysis of Marginal Price Variation with an Application in the Identification of Candidate Ethanol Conversion 
Plant Locations. Netw Spat Econ 2002;2(1):79-93.

[35] Panichelli L., and Gnansounou E., GIS-based approach for defining bioenergy facilities location: A case study in Northern Spain based on marginal delivery costs and resources competition between facilities. Biomass Bioenerg 2008;32(4):289-300.

[36] Zhan F.B., Chen X., Noon C.E., and Wu G., A GIS-enabled comparison of fixed and discriminatory pricing strategies for potential switchgrass-to-ethanol conversion facilities in Alabama. Biomass Bioenerg 2005;28(3):295-306.

[37] Perpiñá C., Alfonso D., Pérez-Navarro A., Peñalvo E., Vargas C., and Cárdenas R., Methodology based on Geographic Information Systems for biomass logistics and transport optimisation. Renew Energ 2009;34(3):555-565.

[38] Biomass Research and Development Board, National Biofuels Action Plan, Biomass Research \& Development Initiative, 2008.

[39] Hess, J.R., Wright, C.T., and Kenney, K.L., Cellulosic biomass feedstocks and logistics for ethanol production, Biofuels, Bioproducts\&Biorefining, 2007;1(3):181-190.

[40] Idaho National Laboratory (INL), 2006, Bioenergy Technology, Available at: http://www.inl.gov/bioenergy/projects/d/1006_ch2m.pdf.

[41] Sandia National Laboratories (SNL), and General Motors’ R\&D Center, 2009, 90-Billion Gallon Biofuel Deployment Study: Executive Summary, Available at: http://www.greenbiz.com/sites/default/files/document/Exec_Summary02-2009.pdf.

[42] West, T., Dunphy-Guzman, K., Sun, A., Malczynski, L., Reichmuth, D., Larson, R., Ellison, J., Taylor, R., Tidwell, V., Klebanoff, L., Hough, P., Lutz, A., Shaddix, C., Brinkman, N., Wheeler, C., and O’Toole, D., 2009, Feasibility, economics, and environmental impact of producing 90 billion gallons of ethanol per year by 2030, Available at: http://www.sandia.gov/news/publications/white-papers/90-Billion-GallonBiofuelSAND2009-3076J.pdf.

[43] Reynolds, R.E., 2002, Infrastructure Requirements for an Expanded Fuel Ethanol Industry, South Bend, IN: Oak Ridge National Laboratory Ethanol Project, http://www.ethanolrfa.org/objects/documents/94/dai.pdf.

[44] Gronalt M., and Rauch P., Designing a regional forest fuel supply network, Biomass Bioenerg 2007;31:393-402.

[45] Gunnarsson H., Ronnqvist M., and Lundgren J.T., Supply chain modeling of forest fuels, Eur J Oper Res 2004;158:103-123.

[46] De Mol R.M., Jogems M.A.H., VanBeek P., and Gigler J.K., Simulation and optimization of the logistics of biomass fuel collection, Neth J Agr Sci 1997;45:219-228.

[47] McNeil Technologies, Inc., Jefferson County Biomass Facility Feasibility Study, 2005, http://frontrangeroundtable.org/uploads/Jeffco_Biomass_Final_Report_01-21-05.pdf.

[48] Sokhansanj S., Kumar A., and Turhollow A.F., Development and implementation of integrated biomass supply analysis and logistics model (IBSAL), Biomass Bioenerg 2006;30:838-847.

[49] Huang Y., Chen C.-W., and Fan Y., Multistage optimization of the supply chains of biofuels. Transportation Research Part E: Logistics and Transportation Review, 2010;46(6):820-830.

[50] Eksioglu S.D., Acharya A., Leightley L.E., and Arora S., Analyzing the design and management of biomass-to-biorefinery supply chain. Computers \& Industrial Engineering 2009;57:1342-1352.

[51] Parker N., Fan Y., and Ogden J., From waste to hydrogen: An optimal design of energy 
production and distribution network. Transportation Research Part E: Logistics and Transportation Review 2007;46:534-545.

[52] Rentizelas A.A., Tatsiopoulos I.P., and Tolis A. An optimization model for multibiomass tri-generation energy supply. Biomass and Bioenergy 2009;33:223-233.

[53] Luo L., Van der Voet E. , and Huppes G. Biorefining of lignocellulosic feedstock Technical, economic and environmental considerations. Bioresource Technology 2010;101(13):5023-5032.

[54] Chiew, Y.L., Iwata, T., and Shimada, S. System analysis for effective use of palm oil waste as energy resources, Biomass and Bioenergy, 2011;35(7):2925-2935.

[55] Kim J., Realff M.J., and Lee J.H. Optimal design and global sensitivity analysis of biomass supply chain networks for biofuels under uncertainty Computers \& Chemical Engineering, 2011;35(9):1738-1751.

[56] Mobini M., Sowlati T., and Sokhansanj S. Forest biomass supply logistics for a power plant using the discrete-event simulation approach Applied Energy, 2011,88(4):12411250.

[57] Dal-Mas M., Giarola S., Zamboni A., and Bezzo F. Strategic design and investment capacity planning of the ethanol supply chain under price uncertainty, Biomass and Bioenergy, 2011;35(5):2059-2071.

[58] Giarola S., Zamboni A., and Bezzo F., Spatially explicit multi-objective optimization for design and planning of hybrid first and second generation biorefineries, Computers \& Chemical Engineering, 2011;35(9):1782-1797.

[59] Marvin A.W., Schmidt, L.D., Benjaafar S., Tiffany D.G., Daoutidis P., Economic optimization of a lignocellulosic biomass-to-ethanol supply chain in the Midwest, Chemical Engineering Science, 2011,In press, doi:10.1016/j.ces.2011.05.055

[60] Perimenis A., Walimwipi H., Zinoviev S., Müller-Langer F., and Miertus S., Development of a decision support tool for the assessment of biofuels, Energy Policy, 2011;39(3):1782-1793.

[61] Parker N., Tittmann P., Hart Q., Nelson R., Skog K., Schmidt A., Gray E., and Jenkins B., Development of a biorefinery optimized biofuel supply curve for the Western United States, Biomass and Bioenergy, 2010;34(11):1597-1607.

[62] Shastri Y., Hansen A., Rodríguez L., and Ting K.C., Development and application of BioFeed model for optimization of herbaceous biomass feedstock production, 2010;35(7):2961-2974.

[63] Kim J., Realff M.J., Lee J.H., Whittaker C., and Furtner L. Design of biomass processing network for biofuel production using an MIPL model, 2011;35:853-871.

[64] Zamboni A., Murphy R.J., Woods J., Bezzo F., and Shah N., Biofuels carbon footprints: whole-system optimization for GHG emissions reduction, Bioresource Technology, 2011;102(16):7457-7465.

[65] Zhang, F., Johnson, D.M., and Sutherland, J.W., A GIS-Based Method for Identifying the Optimal Location for a Facility to Convert Forest Biomass to Biofuel, Biomass and Bioenergy 2011;35(9):3951-3961.

[66] Johnson, D.M., Zhang, F., and Johnson, M.A., Forestry Biofuel Statewide Collaboration Center (FBSCC) Task B4 Final Report, Michigan Technological University, 2011.

[67] Arena simulation software, Available at: http://www.arenasimulation.com/.

[68] U.S. Energy Information Administration. Available at: http://205.254.135.24/oog/info/gdu/dieselpump.html 
Appendix A 


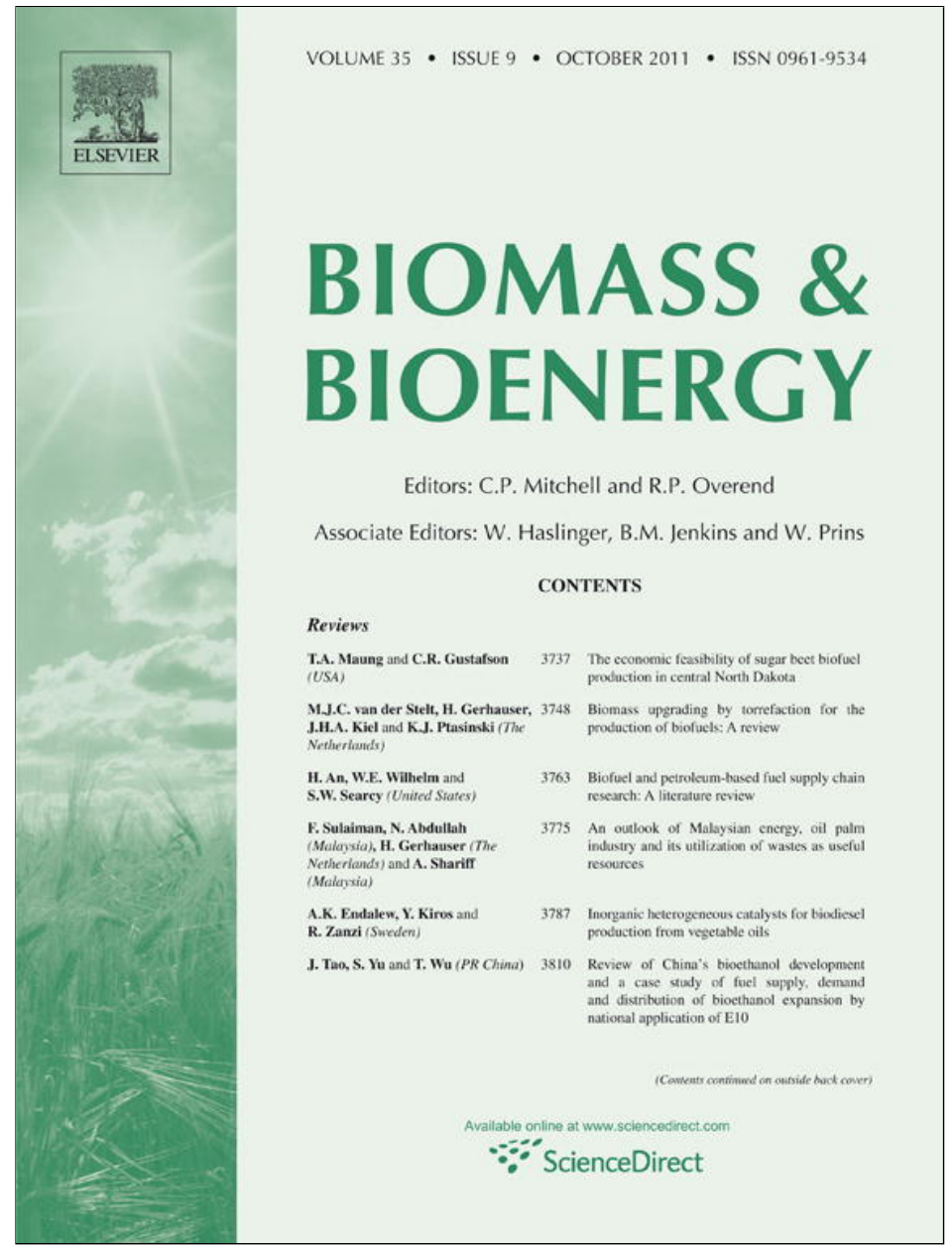

This article appeared in a journal published by Elsevier. The attached copy is furnished to the author for internal non-commercial research and education use, including for instruction at the authors institution and sharing with colleagues.

Other uses, including reproduction and distribution, or selling or licensing copies, or posting to personal, institutional or third party websites are prohibited.

In most cases authors are permitted to post their version of the article (e.g. in Word or Tex form) to their personal website or institutional repository. Authors requiring further information regarding Elsevier's archiving and manuscript policies are encouraged to visit:

http://www.elsevier.com/copyright 


\title{
A GIS-based method for identifying the optimal location for a facility to convert forest biomass to biofuel
}

\author{
Fengli Zhang ${ }^{a}$, Dana M. Johnson ${ }^{b, *}$, John W. Sutherland ${ }^{c}$ \\ a Department of Mechanical Engineering-Engineering Mechanics, Sustainable Futures Institute, Michigan Technological University, \\ 1400 Townsend Drive, Houghton, MI 49931, USA \\ ${ }^{\mathrm{b}}$ School of Business and Economics, Sustainable Futures Institute, Michigan Technological University, 1400 Townsend Drive, \\ Houghton, MI 49931, USA \\ ${ }^{c}$ Division of Environmental and Ecological Engineering, Purdue University, 500 Central Drive, West Lafayette, IN 47907, USA
}

\section{A R T I C L E I N F O}

Article history:

Received 9 August 2010

Received in revised form

19 May 2011

Accepted 2 June 2011

Available online 1 July 2011

Keywords:

GIS

Biomass

Biofuel

Transportation cost

Optimal facility location

\begin{abstract}
A B S T R A C T
There is growing interest in the production of biofuels from woody biomass. Critical to the financial success of producing biofuel is identifying the optimal location for the facility. The location decision is especially important for woody biomass feedstock owing to the distributed nature of biomass and the significant costs associated with transportation. This study introduces a two-stage methodology to identify the best location for biofuel production based on multiple attributes. Stage I uses a Geographic Information System approach to identify feasible biofuel facility locations. The approach employs county boundaries, a county-based pulpwood distribution, a population census, city and village distributions, and railroad and state/federal road transportation networks. In Stage II, the preferred location is selected using a total transportation cost model. The methodology is applied to the Upper Peninsula of Michigan to locate a biofuel production facility. Through the application of the two-stage methodology, the best possible location for biofuel production was identified as the Village of L'anse in Baraga County. Also investigated are the sensitivity of transportation cost and the optimal site for biofuel production to changes in several key variables. These additional variables included fuel price, transportation distance, and pulpwood availability. By applying sensitivity analysis based on limited availability of feedstock, the City of Ishpeming emerged as another viable location for the production facility.
\end{abstract}

(C) 2011 Elsevier Ltd. All rights reserved.

\section{Introduction}

The United States (U.S.) is pursuing several options to create biofuels from renewable biomass and thus reduces dependence on imported fossil fuels and mitigate greenhouse gas (GHG) emissions. Perlack et al. [1] suggest that $30 \%$ of the present consumption of petroleum products can be displaced by biofuels in the U.S. by 2030. A joint biofuels systems analysis project, "90-Billion Gallon Biofuel Deployment Study," conducted by Sandia National Laboratories and the General Motors Research and Development Center, assessed the feasibility, implication, limitations, and enablers of largescale production of biofuels in the U.S. [2]. This study concluded that producing 90 billion gallons (341 billion liters) of biofuels from biomass each year in the U.S. is feasible [3]. Sensitivity analysis also demonstrated that cellulosic biofuels can compete with oil at a reasonable price based on specific assumptions [3].

\footnotetext{
* Corresponding author. Tel.: +1 906487 2803; fax: +1 9064872944.
}

E-mail addresses: fengliz@mtu.edu (F. Zhang), dana@mtu.edu (D.M. Johnson), jwsuther@purdue.edu (J.W. Sutherland). 0961-9534/\$ - see front matter ๑ 2011 Elsevier Ltd. All rights reserved. doi:10.1016/j.biombioe.2011.06.006 
To implement cost-effective biofuel production, the selection of the best location for a processing facility becomes a critical concern. This is because biomass feedstock is geographically dispersed, and the location of a biofuel facility significantly influences transportation costs. We present a new two-stage methodology for identifying the optimal facility location for biofuel production from forest biomass. Stage I uses a Geographic Information System (GIS) to identify potential facility locations for biofuel production from forest biomass for a given study area. The GIS analysis takes into account the following factors: (a) county boundaries, (b) a railroad transportation network, (c) a state/federal road transportation network, (d) city and village distributions, (e) a population census, and ( $\mathrm{f}$ ) a pulpwood production. In stage II, a rectangular grid system is established across the study area using the Public Land Survey System (PLSS). ${ }^{1}$ Using the PLSS, a total transportation cost model is then established and utilized to find the optimal site for biofuel production from forest biomass. Our study focused on low value pulpwood, primarily used by paper mills, as the feedstock for biofuel production. Ince and Durbak [4] stated that declining demand for pulpwood by the paper products industry has led to alternative uses for a readily available woody biomass feedstock. In the Southern U.S. (the major pulp producing area), pulpwood demand decreased by $7.5 \%$ from 1994 to 2003 while the supply of pulpwood increased due to increased acreage and improved management intensity of pine plantations $[5,6]$. Total U.S. pulpwood demand was forecast to continue declining in the next decade by the USDA Forest Service and surplus pulpwood can be used for ethanol production [6]. The process technologies used to convert forest residues to lignocellulosic ethanol can be applied to pulpwood feedstock.

The research begins with a brief literature review that describes previous work that has been conducted on the facility location problem, with specific emphasis on biofuel production facilities. Special attention is placed on research relating to the application of GIS to site selection. Next, the two-stage methodology for identifying the optimal location for biofuel production from forest biomass is described. The methodology is then applied in a case study for Michigan's Upper Peninsula (or the U.P. of Michigan) to identify the best site to locate a facility. Following the case study, a sensitivity analysis is performed to assess the effect of several key variables, i.e., fuel price, transportation distance, and pulpwood availability, on transportation cost. Sensitivity analysis also revealed an alternative production site if biomass availability is less than expected. Lastly we summarize our research findings, describe important conclusions, and present guidance for future research.

\section{Literature review}

A variety of methodologies for facility location decision making were reviewed that have been presented in the

\footnotetext{
${ }^{1}$ PLSS was developed by the Land Ordinance of 1785 and is a method used in U.S. to survey and identify land. Its basic units of area are the township and section. The PLSS typically divides land into 6-mile-square townships. Townships are subdivided into 36 one-mile-square sections.
}

technical literature. We focused on traditional facility location analysis techniques, including basic quantitative methods and methods using both qualitative and quantitative criteria. Then, approaches that combine GIS systems with other models were evaluated. Lastly, GIS-based approaches that have been employed to address issues related to bioenergy facility locations were examined.

Facility location problems may be classified into two main categories: single facility location and multi-facility location [7]. One technique for making single facility location decisions is the Weber model, which employs a center-of-gravity approach for site selection, and was employed by Drezner and Wesolowsky [8] and Wesolowsky [9]. Various techniques for locating multiple facilities simultaneously were studied by Brimberg et al., such as alternative location-allocation, projection, Tabu search, p-median, genetic search, and different variable neighborhood searches [10]. Additional traditional facility location analysis techniques include location rating factor and load-distance [11].

Several basic quantitative methods for location selection have been applied in prior research and are relevant to this research study. These include mathematical modeling approaches such as data envelopment analysis modeling and binary integer linear programming model [12]. Approaches considering both qualitative and quantitative criteria for selecting the optimal location for a new facility were developed and applied, including Blin's fuzzy model, the fuzzy synthetic evaluation, Yager's weighted goals method, and fuzzy analytic hierarchy process [13]. A hybrid method of selecting the best facility location considered critical factors for the first time, besides the commonly used objective and subjective factors. The critical and subjective factors were defined from decision maker's judgments which are often linked to real word concerns [14]. However, these methods cannot handle spatial data. An important trend in location patterns is using GISbased techniques for making single- and multiple-facility location decisions. The advantage of using GIS-based approach is that GIS is able to analyze both spatial and non-spatial data.

The integrated approaches of GIS and other quantitative and qualitative models, have been developed and applied in decision support systems of selecting locations, including a GIS-based simulated annealing algorithm for identifying waste disposal sites [15], an integrated approach of GIS and location-allocation model to identify the best location for public facility planning [16], GIS combined with expert knowledge to determine adequate potential soil aquifer treatment (SAT) sites for groundwater recharge of the Hammamet-Nabeul aquifer located in the 'Cap Bon' peninsula in north east Tunisia [17], an integrated approach of GIS technology and a landfill diagnosis method to assist in landfill sitting assessment [18], and an integrated model of GIS and fuzzy logic for taxicab stand location decision [19]. The capability of handling spatial data of GIS was employed to analyze spatial associations between geothermal exploration and environmental evidence layers to determine the appropriate sites for exploratory wells in the Northwest Sabalan geothermal field [20]. In a word, the integrated approaches of GIS and other quantitative and qualitative models have been proved to be an effective method in decision support systems of selecting locations. 
With the growing interest in exploring renewable energy usage, GIS has proved to be an effective tool to address issues related to biomass availability and biomass logistics. Graham et al. [21] utilized GIS for a state-level modeling system to estimate regional geographic variations on delivered energy crop feedstock costs, and environmental impacts of switching from conventional crops to energy crops. Frombo et al. [22] introduced the GIS-based Environmental Decision Support System (EDSS) for strategic planning of optimal forest biomass logistics. Haddad and Anderson [23] identified potential supply locations of corn stover for bioenergy production by applying GIS. Voivontas et al. [24] estimated the biomass potential for power production from agriculture scraps based on GIS.

Certain features of GIS have been applied to address issues related to bioenergy facility locations. A proposed algorithm for generating a marginal price (or maximum delivered cost) surface was developed by Noon et al. [25] using a GIS-based analysis to identify potential ethanol conversion plant locations. The marginal price was composed primarily of transportation cost without considering farmgate price and competition for feedstock of nearby potential plants. Employing the marginal price surface approach for locating bioenergy facilities location, Panichelli and Gnansounou [26] considered site competition for biomass resources to develop a methodology for farmgate price calculation. A delivery cost surface based on GIS technology to compare two pricing strategies, fixed and discriminatory, was developed by Zhan et al. [27] to evaluate the economic variability of building a switchgrass-toethanol conversion facility in Alabama. Perpina et al. [28] applied GIS to analyze and identify optimal biomass logistics and transport strategies to locate bioenergy plants.

Based on the study on previous literature, a two-stage methodology was developed and described below.

\section{A new methodology for facility location}

As has been noted, we propose a two-stage methodology to identify the best location for biofuel production facility. The two stages are (1) identify potential pulpwood-to-biofuel facility locations based on a GIS approach (stage I), and (2) selection of the optimal biofuel facility location based on a total transportation cost model (stage II). Fig. 1 outlines the steps in each stage and shows the relationship between the two stages [29].

\subsection{Stage I: site candidate identification via GIS}

The purpose of stage I (Fig. 1) within the methodology is to utilize GIS to identify potential pulpwood-to-biofuel facility locations. Six types of information were considered in the GIS analysis: (a) county boundaries, (b) a railroad transportation network, (c) a state/federal road transportation network, (d) city and village distributions, (e) a population census, and (f) pulpwood production. County boundaries form the spatial basis of the GIS analysis. State/federal road and railroad transportation networks were incorporated to ensure timely delivery of biomass feedstock and biofuels. Truck transportation was included because it is the principal method of transporting feedstock and biofuels in stage II. The railroad network is another delivery alternative because it offers a lower transportation cost than trucking.

In the application of GIS, several assumptions were made. These included

- Low-valued pulpwood was chosen as the feedstock for the potential biofuel facility because of the declining demand for pulpwood by the paper products industry and the increasing supply due to increased acreage and improved management intensity of pine plantations [4-6].

- The annual pulpwood availability is assumed to be uniformly distributed within each county in the region of interest. Pulpwood data is available from the USDA Forest Service, Forest Inventory and Analysis National Program. The original data is provided in cubic foot and was converted to tonne (conversion factors of 30 dry lbs per cubic foot $\left(481 \mathrm{~kg} \mathrm{~m}^{-3}\right)$ [1] and $2205 \mathrm{lbs}$ per $\mathrm{Mg}$ or one tonne was used).

- The biofuel facility will operate at a production rate of 189 million liters (50 million gallons) of biofuel per year, which is a medium-sized biofuel facility, as discussed in Ref. [30]. The biofuel facility size was determined by investigating the tradeoff between economies of biorefinery size and feedstock transportation costs [30].

- Based on a conversion yield of $334 \mathrm{~L} \mathrm{Mg}^{-1}$ (80 gallons dry ton $^{-1}$ ) of woody biomass [31], a higher quantity of $635,000 \mathrm{Mg}$ (700,000 tons) of dry feedstock will be required per year by accounting for dry matter loss during storage and transportation.

- Accessibility to the state/federal road transportation network and the railroad transportation network (i.e., the facility is within $1.61 \mathrm{~km}$ (one mile) of a network) is required. This guarantees that the input (pulpwood feedstock) and output (biofuel products) can be easily transported.

- Only cities and villages with populations greater than 1000 were considered for locating the biofuel facility, to ensure the availability of a workforce.

Based on these assumptions, the GIS algorithm can identify potential locations for pulpwood-to-biofuel conversion facilities. GIS operations are the central part of the methodology for the stage I analysis. The GIS operation consists of the eight steps that are described in Appendix. In short, the steps record the basic geographic and demographic data for the region of interest, define the biomass density for each county, select cities/villages within $1.61 \mathrm{~km}$ (one mile) of a state/ federal road or railroad; and from this reduced set of cities/ villages, identify those municipalities with a population greater than 1000 . These municipalities are the candidate sites identified from stage I analysis and that will serve as input for stage II of the analysis.

\subsection{Stage II: cost-optimal location}

The objective of stage II of the methodology is to identify the cost-optimal location for biofuel production from forest biomass. Stage II builds upon the results of stage I, which used a GIS-based approach that considered a variety of important factors (Fig. 1) to select a number of candidate facility sites. The potential sites identified in stage I serve as unique 

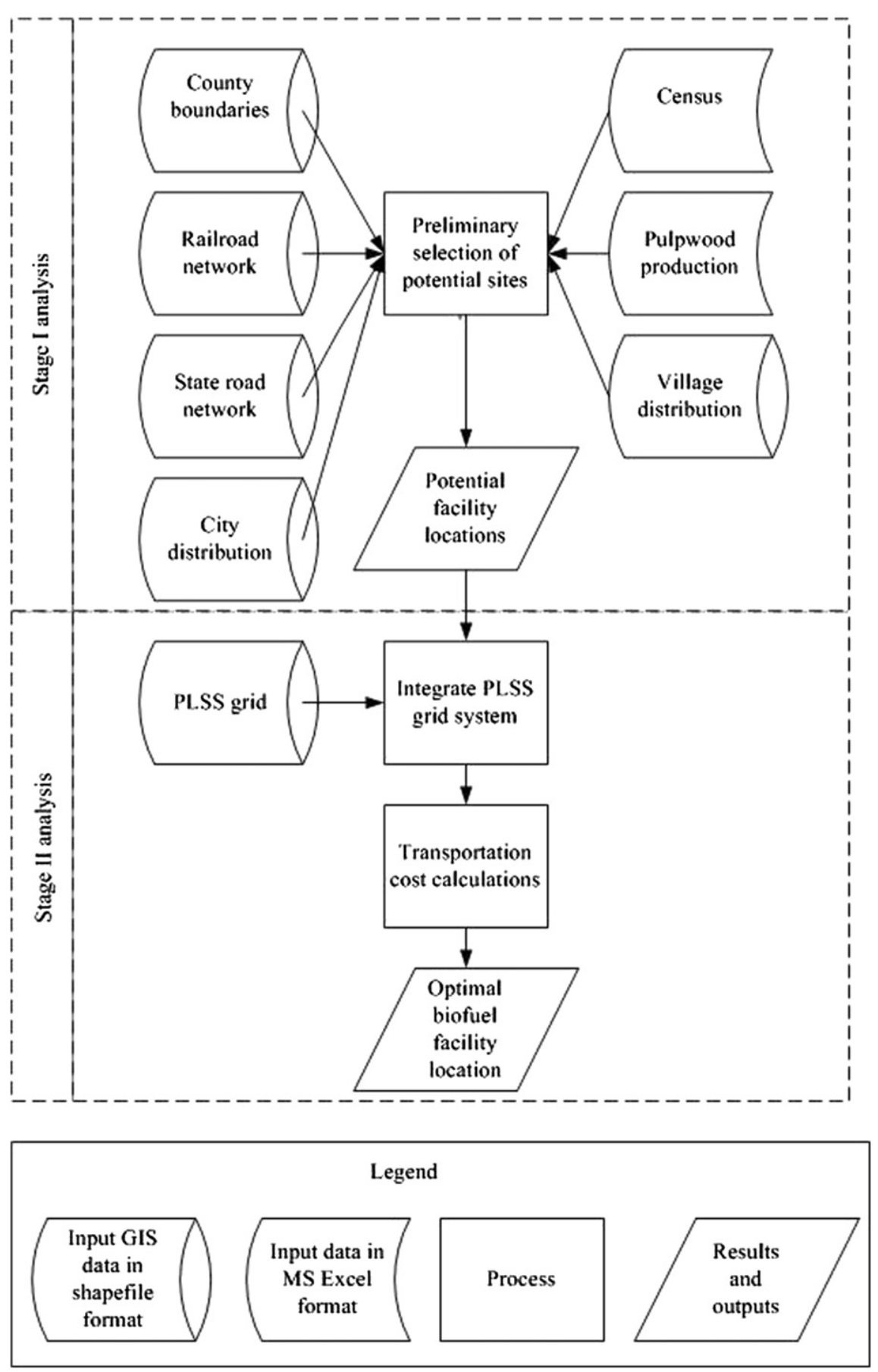

Fig. 1 - Overview of methodology.

demand locations/points for stage II. The rectangular grid system establishes a set of 1 mile $\times 1$ mile cells (the minimum information unit) across the study area of interest. The cost considered in this study is the total transportation cost when the $635,000 \mathrm{Mg}$ (700,000 tons) of demand is met. The model considers each candidate facility location as a demand point. For a given demand point, the model calculates the rectilinear distances between the demand point and a number of supply points (centroids of the PLSS cells). These distances are used as approximations of the actual transportation distances. The weights are the quantity of biomass in each cell. The optimal site for biofuel production from forest biomass is identified as the site with the minimum total transportation cost.

\subsubsection{Relation for transportation cost rate}

The relation for transportation cost rate is based on the work presented by Hicks [32]. In this prior effort, three companies from the U.P. of Michigan were investigated for their cost structure. The trucking cost associated with transporting a variety of loads under different fuel prices was recorded. A linear regression equation was established based on the data, and is shown in Equation (1): 


$$
\mathrm{C}_{\mathrm{T}}=4.29+0.0459 \times \mathrm{d}+0.0078 \times \mathrm{C}_{\mathrm{F}}-0.705 \times \mathrm{d} .
$$

In Equation (1), $\mathrm{C}_{\mathrm{T}}$ is the one-way transportation rate $\left(\$ \mathrm{Mg}^{-1}\right)$ from a supply point to a demand point, $d$ is the one-way transportation distance $(\mathrm{km})$ from a supply point to a demand point, and $C_{F}$ is the fuel price $\left(\$ \mathrm{~L}^{-1}\right)$. This transportation cost rate is, in effect, a transportation cost per unit. The coefficient of determination for the fitted line was $\mathrm{R}^{2}=0.9703$ [32]. The equation consists of three components: fixed cost, variable (distance-dependent) cost, and fuel cost differential. The fixed cost rate of $4.29 \$ \mathrm{Mg}^{-1}$ covers the cost of loading and unloading the biomass and other miscellaneous expenses [32].

The constant coefficient associated with fuel cost, $0.705 \$ \mathrm{~L}^{-1}$, corresponds to average fuel cost for Oct 2009 [32]. In general, the actual fuel cost will not be equal to this cost. If the fuel cost is indeed $0.705 \$ \mathrm{~L}^{-1}$, the one-way transportation cost rate $\left(\$ \mathrm{Mg}^{-1}\right), \mathrm{C}_{\mathrm{T}}$, simplifies to:

$\mathrm{C}_{\mathrm{T}}=4.29+0.0459 \times \mathrm{d}$.

\subsubsection{Total transportation cost model}

The total transportation cost model uses the transportation cost rate relation established above in concert with the supply-demand distances and the amount of available biomass to calculate the total transportation cost. The procedure for finding the total transportation cost for the candidate facility sites is shown below.

Candidate facility locations may be denoted as demand points $(j=1,2,3, \ldots, m)$. The study area is divided into $N$ cells (the area of each cell is one square mile). A pixel is placed at the centroid of each cell, and this pixel serves as the supply point for the cell. Associated with each supply point $(\mathrm{k}=1,2, \ldots, \mathrm{N})$ is the quantity $\left(\mathrm{Q}_{\mathrm{k}}\right)$ of pulpwood available. The quantity $(\mathrm{Mg})$ of pulpwood $\mathrm{Q}_{\mathrm{k}}$ is calculated as:

$\mathrm{Q}_{\mathrm{k}}=\left(\mathrm{Q}_{\mathrm{c}} \times \mathrm{A}_{\mathrm{k}}\right) / \mathrm{A}_{\mathrm{c}}$

where $Q_{c}$ is the total quantity $(\mathrm{Mg})$ of pulpwood that may be renewably recovered annually for a county, $A_{k}$ is the area $\left(\mathrm{km}^{2}\right)$ of the kth cell, and $A_{c}$ is the area $\left(\mathrm{km}^{2}\right)$ of a county.

For the jth demand point the rectilinear distance $(\mathrm{km})$ is calculated for all possible supply (k) points. The $\mathrm{N}$ cells are reordered and renumbered $(i=1,2, \ldots, N)$ from the lowest to the highest based on the rectilinear distance. The available quantity $(\mathrm{Mg})$ of biomass is then summed across the supply points beginning with the shortest distance until the sum meets or exceeds $635,000 \mathrm{Mg}$ (the amount of biomass needed to meet the demand of the processing facility). The number of supply points that must be considered to meet this condition is termed $n$. When this condition is met, $D_{j}(\mathrm{Mg})$ is set equal to the sum as displayed in Equation (4):

$\mathrm{D}_{\mathrm{j}}=\sum_{\mathrm{i}=1}^{\mathrm{n}} \mathrm{Q}_{\mathrm{i}}$

where $\mathrm{Q}_{\mathrm{i}}$ is the annual quantity $(\mathrm{Mg})$ of biomass available at the ith supply point, and $\mathrm{D}_{\mathrm{j}}$ is the total amount $(\mathrm{Mg})$ of biomass supplied from the $\mathrm{n}$ supply points.

The transportation cost associated with delivering the biomass at the supply points to the candidate facility may now be determined by multiplying the cost rate for each of the $n$ supply points by the associated biomass at that point. The transportation cost rate corresponding to the ith supply point and the jth demand point is termed $\mathrm{C}_{\mathrm{ij}}\left(\$ \mathrm{Mg}^{-1}\right)$, and found using Equation (1) (the rectilinear distance $(\mathrm{km})$ between the ith supply point and the $j$ th candidate facility location, $d_{i j}$, is calculated and used in the transportation cost rate). The total transportation cost for the jth demand point, $\mathrm{TC}_{\mathrm{j}}(\$)$, is then found using Equation (5).

$\mathrm{TC}_{\mathrm{j}}=\sum_{\mathrm{i}=1}^{\mathrm{n}}\left(\mathrm{C}_{\mathrm{ij}} \times \mathrm{Q}_{\mathrm{i}}\right)$

The average transportation cost per unit of biomass $\left(\$ \mathrm{Mg}^{-1}\right)$ for the jth demand point, $\mathrm{ATCU}_{j}$, is calculated using Equation (6) by dividing the total transportation cost for the jth demand point $\left(\mathrm{TC}_{\mathrm{j}}\right)$ by the total demand at demand point $j\left(\mathrm{D}_{\mathrm{j}}\right) . \mathrm{ATCU}_{\mathrm{j}}$ is given by:

$\mathrm{ATCU}_{j}=\mathrm{TC}_{\mathrm{j}} / \mathrm{D}_{\mathrm{j}}$

The total transportation distance $(\mathrm{km})$ associated with the jth demand point, $\mathrm{TD}_{\mathrm{j}}$, is calculated with Equation (7):

$\mathrm{TD}_{\mathrm{j}}=\sum_{\mathrm{i}=1}^{\mathrm{n}} \mathrm{d}_{\mathrm{ij}} \times \mathrm{Q}_{\mathrm{i}}$

where $d_{i j}$ is the rectilinear distance $(\mathrm{km})$ between the ith supply point and the jth candidate facility location.

Finally, the average transportation distance per unit of biomass $\left(\mathrm{km} \mathrm{Mg}^{-1}\right)$ for the jth demand point, $\operatorname{ATDU}_{j}$, is calculated using Equation (8):

$\mathrm{ATDU}_{\mathrm{j}}=\mathrm{TD}_{\mathrm{j}} / \mathrm{D}_{\mathrm{j}}$

Next, the two-stage methodology described above is applied in a case study for Michigan's Upper Peninsula.

\section{Case study for Michigan's upper peninsula}

Forest resources, a widely available source of sustainable biomass, hold promise for energy production in Michigan [33], since more than half of State's land area is classified as forestland. A study of growth/removal ratios, calculated for the Great Lakes States from the national forest inventory, suggests significant opportunities for forest biomass as a biofuel feedstock [34]. Since $80 \%$ of the land area of Upper Peninsula of Michigan is forested it was selected as the region of interest to apply the methodology established above.

\subsection{GIS identification of promising locations for a biofuel facility}

Data required for stage I analysis, including county boundaries of the U.P., the railroad transportation network, the state/federal road transportation network, and city and village locations in the U.P., was retrieved from the Michigan Geographic Data Library [35]. Michigan census data was obtained from the U.S. Census Bureau. The census data for all cities and villages in the U.P. in 2006 was integrated into a GIS data layer. The amount of forest biomass for biofuel production was obtained from the USDA Forest Service, Forest 
Inventory and Analysis National Program. Timber Product Output (TPO) Reports [36] include total timber product output as the volume harvested from all sources. Low-valued pulpwood was chosen as the feedstock for the potential biofuel facility because it is an underutilized, abundant resource in the L.P. Table 1 shows annual pulpwood production by county in 2006. Using conversion factors of $30 \mathrm{lbs}$ (dry weight basis) per cubic foot $\left(481 \mathrm{~kg} \mathrm{~m}^{-3}\right)$ [1] and $2205 \mathrm{lbs} \mathrm{Mg}^{-1}$, the total amount of pulpwood that may be annually harvested sustainably is about 1.36 million $\mathrm{Mg}$ (1.50 million tons), which exceeds the demand requirements for a processing facility.

Based on an analysis of all the decision factors impacting pulpwood-to-biofuel facility location, thirteen candidate biofuel facility locations (Table 2) were identified: four villages and nine cities. The potential sites were transferred into point geometry and represented the demand points. All candidate sites are accessible to the state/federal road transportation network and the railroad transportation network: each is less than $1.61 \mathrm{~km}$ (one mile) from a network. This guarantees that the input (pulpwood feedstock) and output (biofuel product) can be easily transported. Also, each candidate site has access to more than $635,000 \mathrm{Mg}$ (700,000 tons) of pulpwood available for biofuel production. Furthermore, to ensure the biofuel facility has enough workers, each candidate site has a population greater than 1000. The spatial location of these candidate sites is shown in the map in Fig. 2.

Based on the preliminary selection of potential sites for biofuel production from forest biomass, attention turned to performing stage II of the methodology.

\subsection{Determining the optimal biofuel facility location}

Based on the stage I analysis, thirteen potential city/village sites in the U.P. of Michigan were identified for a biofuel production facility. These serve as inputs for the stage II analysis, which seeks to identify the best location by applying the total transportation cost model.

Table 1 - Annual pulpwood production for the U.P. 2006.

\begin{tabular}{lrrr} 
County & \multicolumn{3}{c}{ Pulpwood quantity } \\
\cline { 2 - 4 } & $1000 \mathrm{cu} \mathrm{ft}$ & 1000 dry lbs & $10,000 \mathrm{dry} \mathrm{Mg}$ \\
\hline Alger & 4734 & 142,020 & 6.44 \\
Baraga & 7666 & 229,980 & 10.43 \\
Chippewa & 3670 & 110,100 & 4.99 \\
Delta & 7224 & 216,720 & 9.83 \\
Dickinson & 5884 & 176,520 & 8.01 \\
Gogebic & 7910 & 237,300 & 10.76 \\
Houghton & 6887 & 206,610 & 9.37 \\
Iron & 7103 & 213,090 & 9.67 \\
Keweenaw & 3334 & 100,020 & 4.54 \\
Luce & 4294 & 128,820 & 5.84 \\
Mackinac & 3794 & 113,820 & 5.16 \\
Marquette & 16,573 & 497,190 & 22.55 \\
Menominee & 5468 & 164,040 & 7.44 \\
Ontonagon & 8026 & 240,780 & 10.92 \\
Schoolcraft & 7398 & 221,940 & 10.07 \\
Total & 99,965 & $2,998,950$ & 136.03 \\
\hline
\end{tabular}

Table 2 - Potential sites for biofuel production from pulpwood in the U.P.

\begin{tabular}{llcc} 
City/village & County & Longitude & Latitude \\
\hline Newberry & Luce & -85.51 & 46.35 \\
L'anse & Baraga & -88.45 & 46.75 \\
Baraga & Baraga & -88.49 & 46.78 \\
Ontonagon & Ontonagon & -89.31 & 46.87 \\
Menominee & Menominee & -87.62 & 45.12 \\
Norway & Dickinson & -87.91 & 45.80 \\
Iron Mountain & Dickinson & -88.06 & 45.83 \\
Gladstone & Delta & -87.04 & 45.85 \\
Manistique & Schoolcraft & -86.25 & 45.96 \\
Munising & Alger & -86.64 & 46.42 \\
Sault Ste Marie & Chippewa & -84.37 & 46.48 \\
Ishpeming & Marquette & -87.67 & 46.49 \\
Negaunee & Marquette & -87.60 & 46.50 \\
\hline
\end{tabular}

The first step in the stage II analysis was to apply the PLSS grid system to the U.P. of Michigan to create cells of one square mile [37]. To calculate the potential pulpwood within each cell, a GIS operation was performed where the PLSS grid layer was intersected with the county layer, the latter layer having been joined with the pulpwood availability information. The quantity of pulpwood associated with each cell was calculated using Equation (3).

As has been noted, a pixel is created at the centroid of each cell in the PLSS grid; this pixel serves as a potential supply point for each demand point. The GIS application is used to calculate the rectilinear distance associated with every pair of supply and demand points that is considered. As a base case, the fuel price was assumed to be $0.705 \$ \mathrm{~L}^{-1}$ [32]. Therefore, the simplified transportation cost rate relation, Equation (2), was used to calculate the transportation rate.

The methodology discussed above was applied to each candidate facility location (demand point). For every demand point, transportation distances were calculated for the supply points, and sorted from the smallest to largest. Then sufficient supply points were considered to ensure that facility biomass demand of $635,000 \mathrm{Mg}(700,000$ tons) would be met. The TC, ATCU, TD and ATDU were calculated using Equation (6).

Based on the case study, the optimal site for biofuel production from forest biomass in the U.P. of Michigan was identified to be the Village of L'anse in Baraga County (Table 3). A total of 8021 supply points were needed (Fig. 3) to provide the biomass for the L'anse-based biofuel facility.

Table 3 displays the TC values for each candidate site, with the costs displayed from lowest to highest. The L'anse has the smallest TC of 4.32 million $\$$ and ATCU at $6.81 \$ \mathrm{Mg}^{-1}$. The Sault Ste Marie has the highest estimated TC and ATCU at 7.50 million $\$$ and $11.82 \$ \mathrm{Mg}^{-1}$ respectively. The estimated TD for Sault Ste Marie is about 115 million $\mathrm{km}$ and the ATDU for the City of Sault Ste Marie is approximately $164.15 \mathrm{~km} \mathrm{Mg}^{-1}$. The estimated TD for L'anse is about 38 million $\mathrm{km}$. While the ATDU for a site in L'anse is approximately $54.72 \mathrm{~km} \mathrm{Mg}^{-1}$, some biomass will have to be transported longer distances and some closer distances; the histogram shown in Fig. 4 shows the distribution associated with how far the biomass must be transported.

Followed analysis examines the sensitivity of the solutions obtained from the proposed methodology to changes in these assumptions. 


\section{Potential Sites for Biorefinery in the U.P.}

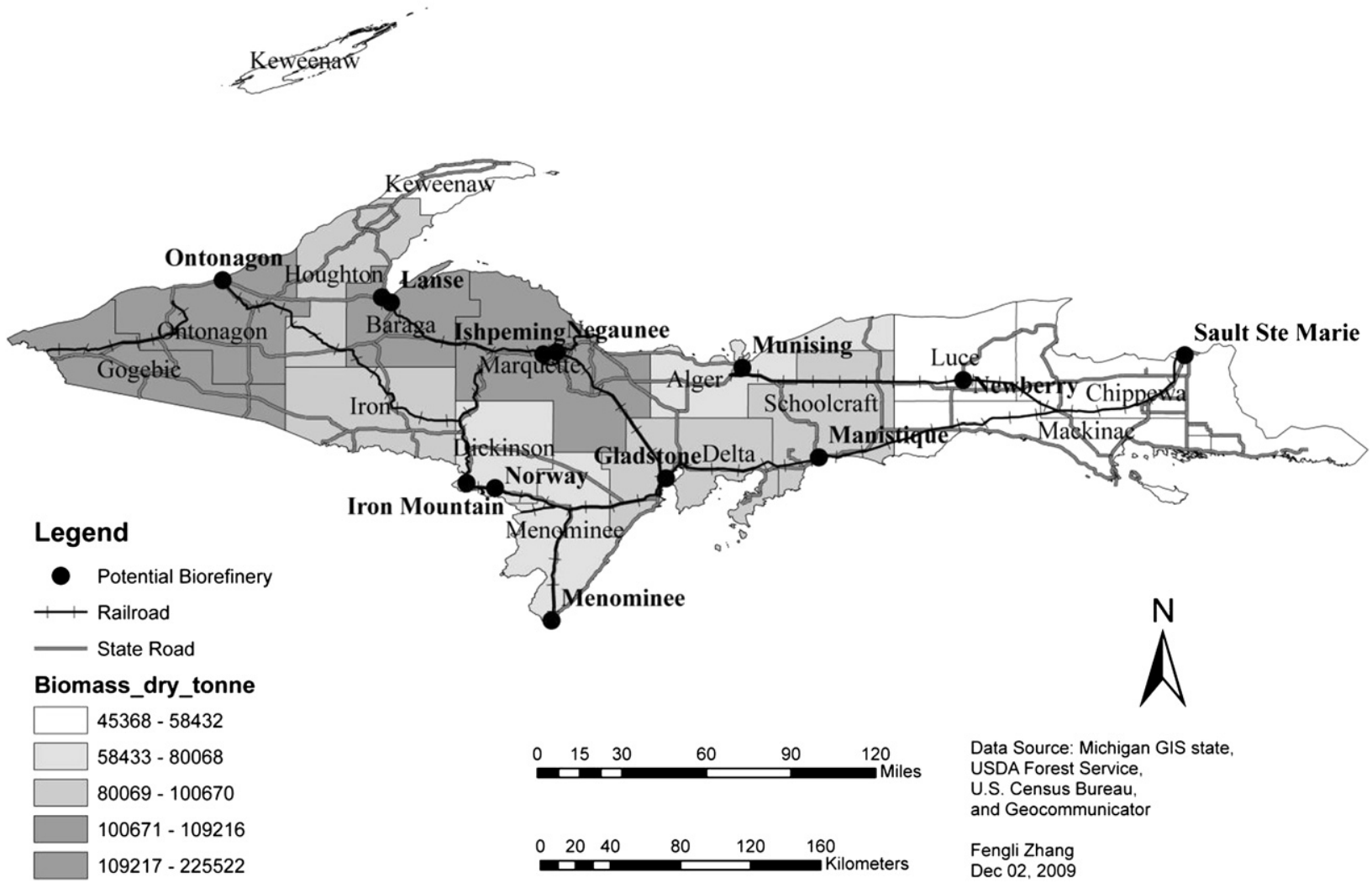

Fig. 2 - Potential sites for biofuel production in the U.P.

\section{Sensitivity analysis and discussion}

The foregoing analysis made a number of assumptions, e.g., a fuel price of $0.705 \$ \mathrm{~L}^{-1}$. With this in mind, a series of analyses were conducted to identify the sensitivity of the transportation cost and optimal site selected for the biofuel facility to influential parameters. This sensitivity analysis considered three parameters: fuel price, distance function employed, and pulpwood availability. For investigating the sensitivity to changes in fuel price and pulpwood availability, deviations from the base case were considered. The methodology described above utilized a rectilinear distance function between supply and demand points to estimate transportation distance; the effect of using a Euclidean distance function was also considered. The TC and ATCU were calculated for each case examined.

\subsection{Fuel price influence on transportation cost}

In the case study for the U.P. of Michigan, fuel price played an important role in the transportation cost model. In order to evaluate the effect of fuel price on the cost, the alternative fuel prices shown in Table 4 were evaluated for the L'anse-based biofuel facility. The prices considered were (i) the average fuel price for 2007 (2007 avg.), (ii) the highest price for 2007
(2007 max.), (iii) the lowest price for 2007 (2007 min.), and (iv) the highest price for the five years between 2005 and 2009 (5 yr. max). The estimated TC and ATCU for the L'anse facility location for the different fuel prices are shown in Table 4.

First, it should be noted that any change in the fuel price will have no effect on the optimal location for the biofuel

Table 3 - Estimated TC, ATCU, TD and ATDU for each potential site in the U.P.

\begin{tabular}{lcccc} 
City/village & $\begin{array}{c}\text { TC } \\
\text { (million } \$)\end{array}$ & $\begin{array}{c}\text { ATCU } \\
\left(\$ \mathrm{Mg}^{-1}\right)\end{array}$ & $\begin{array}{c}\text { TD } \\
(\text { million } \mathrm{km})\end{array}$ & $\begin{array}{c}\text { ATDU } \\
\left(\mathrm{km} \mathrm{Mg}^{-1}\right)\end{array}$ \\
\hline L'anse & 4.32 & 6.81 & 38.42 & 60.49 \\
Baraga & 4.35 & 6.86 & 39.16 & 61.65 \\
Ishpeming & 4.36 & 6.87 & 39.37 & 62.00 \\
Negaunee & 4.42 & 6.97 & 40.84 & 64.31 \\
Gladstone & 4.73 & 7.44 & 48.11 & 75.77 \\
Munising & 4.76 & 7.50 & 49.02 & 77.19 \\
Norway & 4.77 & 7.52 & 49.24 & 77.52 \\
Iron Mountain & 4.83 & 7.61 & 50.64 & 79.72 \\
Ontonagon & 4.93 & 7.76 & 52.94 & 83.36 \\
Manistique & 5.04 & 7.94 & 55.70 & 87.71 \\
Newberry & 5.36 & 8.45 & 63.45 & 99.93 \\
Menominee & 6.59 & 10.38 & 92.88 & 146.25 \\
Sault Ste Marie & 7.50 & 11.82 & 114.82 & 180.95 \\
\hline
\end{tabular}




\section{Supply Region for the L'anse Facility Location}

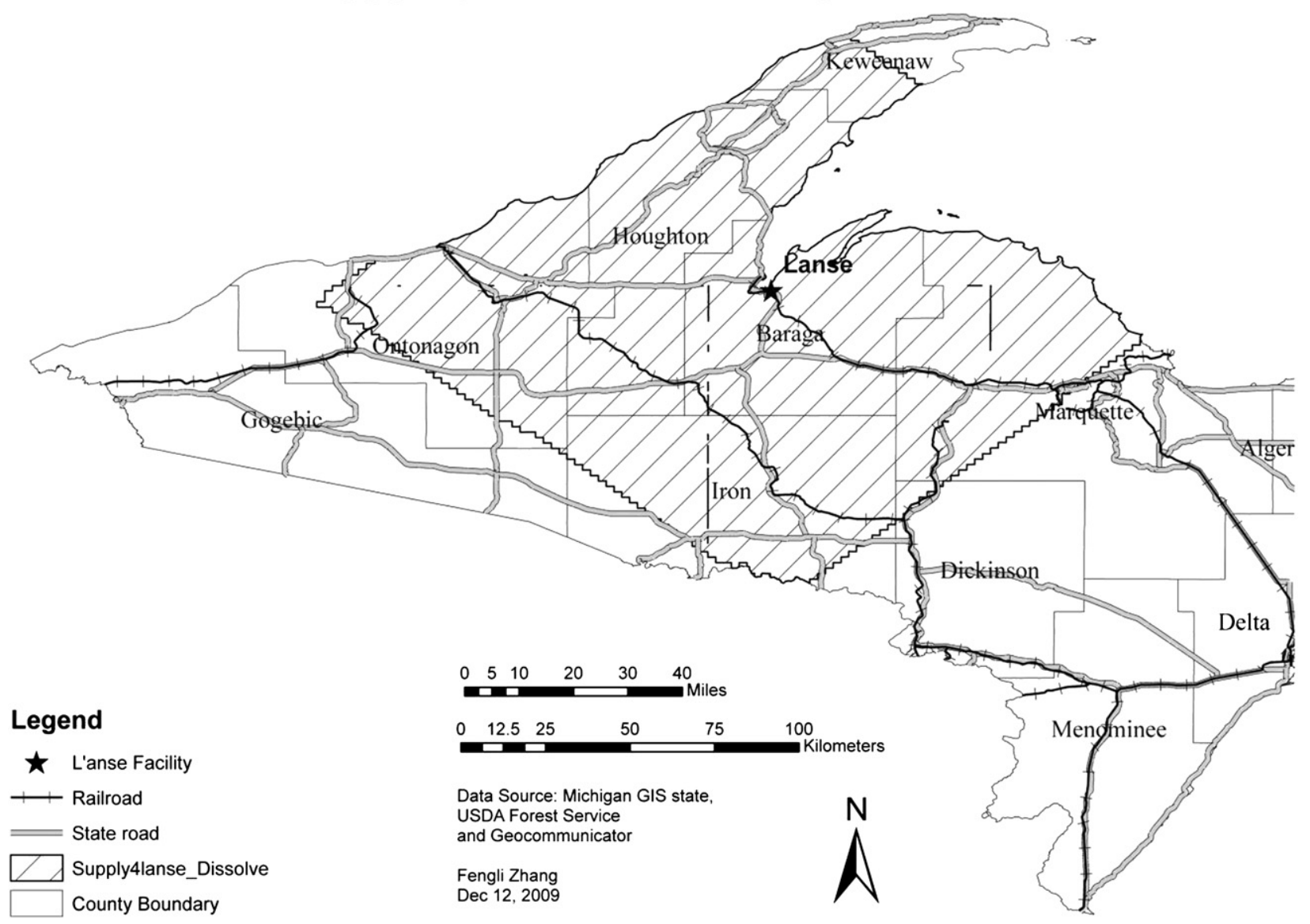

Fig. 3 - Supply region for the L'anse facility location.

facility. The selection of the optimal location for the biofuel production depends on the biomass distribution around demand points. In Table 4 it is clearly evident that both the TC and the ATCU change in proportion to the fuel price. The smallest TC is approximately 4.25 million $\$$, corresponding to the minimum fuel price of $0.637 \$ \mathrm{~L}^{-1}$; the associated ATCU is $6.70 \$ \mathrm{Mg}^{-1}$. The largest TC is 4.89 million $\$$, for the $5 \mathrm{yr}$. max fuel price of $1.258 \$ \mathrm{~L}^{-1}$, and the resulting ATCU is $7.70 \$ \mathrm{Mg}^{-1}$.

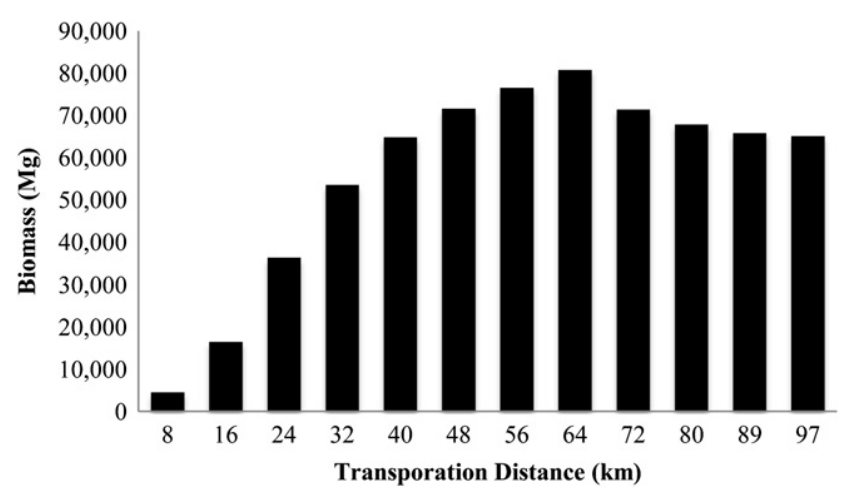

Fig. 4 - Distance traveled by biomass for the L'anse facility location.

\subsection{Distance function influence on transportation cost}

The influence of utilizing a Euclidean distance function on transportation cost was explored. With L'anse as the facility site, the Euclidean distance function produces an ATDU of $43.45 \mathrm{~km} \mathrm{Mg}^{-1}$ (as opposed to the $54.72 \mathrm{~km} \mathrm{Mg}^{-1}$ found with the rectilinear distance function). A tortuosity factor (the product of the tortuosity factor and the Euclidean distance is the actual distance traveled) was introduced into the Euclidean distance function to account for irregularities in the road network connecting supply regions and a biofuel production facility [38-41]. Tortuosity factors ranging from 1.0 to 3.0 [38] were considered. The adjusted Euclidean distances

Table 4 - Estimated TC and ATCU for the L'anse biofuel facility on different fuel prices.

\begin{tabular}{lccc} 
Date & $\begin{array}{c}\text { Diesel fuel } \\
\text { price }\left(\$ \mathrm{~L}^{-1}\right)\end{array}$ & $\begin{array}{c}\text { TC } \\
\text { (million } \$)\end{array}$ & $\begin{array}{c}\text { ATCU } \\
\left(\$ \mathrm{Mg}^{-1}\right)\end{array}$ \\
\hline Oct 2009 avg. & 0.705 & 4.32 & 6.81 \\
2007 avg. & 0.763 & 4.38 & 6.90 \\
2007 min. & 0.637 & 4.25 & 6.70 \\
2007 max. & 0.909 & 4.53 & 7.14 \\
5 yr. max & 1.257 & 4.89 & 7.70 \\
\hline
\end{tabular}


Table 5 - ATDU, TC, and ATCU for a biofuel facility in L'anse based on a Euclidean distance function and different tortuosity factors (for reference, the Euclidean distance function produces an ATDU of $47.91 \mathrm{~km} \mathrm{Mg}^{-1}$ ).

\begin{tabular}{lccc}
$\begin{array}{l}\text { Tortuosity } \\
\text { factor }\end{array}$ & $\begin{array}{c}\text { ATDU } \\
\left(\mathrm{km} \mathrm{Mg}^{-1}\right)\end{array}$ & $\begin{array}{c}\text { TC } \\
(\text { million } \$)\end{array}$ & $\begin{array}{c}\text { ATCU } \\
\left(\$ \mathrm{Mg}^{-1}\right)\end{array}$ \\
\hline 1.0 & 47.91 & 4.00 & 6.30 \\
1.3 & 62.10 & 4.38 & 6.90 \\
1.5 & 72.75 & 4.64 & 7.30 \\
1.7 & 81.62 & 4.89 & 7.70 \\
1.9 & 92.27 & 5.15 & 8.10 \\
2.1 & 101.14 & 5.40 & 8.51 \\
2.3 & 111.78 & 5.66 & 8.91 \\
2.5 & 120.66 & 5.91 & 9.31 \\
2.7 & 129.53 & 6.17 & 9.71 \\
2.9 & 140.17 & 6.42 & 10.11 \\
3.0 & 145.50 & 6.55 & 10.31 \\
\hline
\end{tabular}

were then used as the transportation distances in the transportation cost model for the L'anse-based biofuel facility.

The calculated TC and ATCU for the different tortuosity factors are shown in Table 5. It is clear that as the tortuosity factor increases, so do the values for the TC and the ATCU. For a tortuosity factor of 1.0, the TC, ATCU, and ATDU are 4.00 million $\$, 6.30 \$ \mathrm{Mg}^{-1}$, and $43.45 \mathrm{~km} \mathrm{Mg}^{-1}$ respectively. For the rectilinear distance function, the corresponding values are 4.32 million $\$, 6.81 \$ \mathrm{Mg}^{-1}$, and $54.72 \mathrm{~km} \mathrm{Mg}^{-1}$. For a tortuosity factor of 3.0, the TC is 6.55 million $\$$, the ATCU is $10.31 \$ \mathrm{Mg}^{-1}$ and the ATDU is $131.97 \mathrm{~km} \mathrm{Mg}^{-1}$.

\subsection{Pulpwood availability influence on selection of optimal site}

In the base case study, the amount of pulpwood that could be sustainably harvested annually was taken directly from Table 1 (pulpwood production data). It is likely that not all biomass will be available for a biofuel facility because of other competing uses for the same biomass. Competitors for biomass may come from paper mills, co-fired power plants, and other existing bioenergy facilities. To consider situations where less than $100 \%$ of the low value pulpwood is available for biofuel production in the U.P., several other pulpwood availability percentages were considered: from $50 \%$ to $100 \%$ in increments of $10 \%$. Table 6 illustrates the different optimal sites for biofuel production based on different pulpwood availability levels in the U.P. The City of Ishpeming was identified to be the optimal site for levels of pulpwood availability ranging from $50 \%$ to $70 \%$. L'anse was identified as the optimal

Table 6 - Optimal sites for biofuel facility on different pulpwood availability in the U.P.

\begin{tabular}{llcc}
$\begin{array}{l}\text { Pulpwood } \\
\text { availability (\%) }\end{array}$ & Optimal site & $\begin{array}{c}\text { TC } \\
\text { (million \$) }\end{array}$ & $\begin{array}{c}\text { ATCU } \\
\left(\$ \mathrm{Mg}^{-1}\right)\end{array}$ \\
\hline 50 & Ishpeming & 5.25 & 8.27 \\
60 & Ishpeming & 4.97 & 7.83 \\
70 & Ishpeming & 4.77 & 7.51 \\
80 & L'anse & 4.59 & 7.23 \\
90 & L'anse & 4.44 & 6.70 \\
100 & L'anse & 4.32 & 6.81 \\
\hline
\end{tabular}

site when the pulpwood availability is higher (from $80 \%$ to $100 \%$ ). As has been noted, the selection of the optimal location for biofuel production depends on the biomass distribution around demand points, which explains why the best location shifts as the pulpwood availability changes.

\section{Summary and conclusions}

A two-stage methodology to identify the optimal facility location for biofuel production from forest biomass has been described. Stage I uses a GIS-based approach to identify potential biofuel facility locations for a given region of interest. The GIS analysis considers such factors as the county boundaries, a county-based pulpwood distribution, city and village distributions, population data, and railroad and state/ federal road transportation networks. In stage II, the PLSS is used to generate a grid of one-square-mile cells. A transportation cost model was introduced that sums the costs associated with transporting the sustainably harvestable biomass in each cell to a given potential facility site. The transportation distance is approximated by the rectilinear distance between a pair of supply and demand points. The optimal site for biofuel production is the site that has the minimum transportation cost. The methodology was applied to the U.P. of Michigan as a case study. The optimal location for biofuel production from pulpwood was found to be the Village of L'anse. The influence of fuel price, distance functions employed, and pulpwood availability on transportation cost was evaluated through a series of sensitivity analyses. Sensitivity analysis was also conducted to assess the influence of the availability of pulpwood on the selection of the optimal site for biofuel production.

The conclusions from this research include

- The Village of L'anse was identified to be the optimal location for biofuel production from low-valued pulpwood in the base case study in the U.P. The TC was approximately 4.32 million $\$$ and the ATCU was estimated to be $6.81 \$ \mathrm{Mg}^{-1}$ with an ATDU of $54.72 \mathrm{~km} \mathrm{Mg}^{-1}$.

- The sensitivity analysis showed that fuel prices, transportation distance, and pulpwood availability have influence on transportation cost. Pulpwood availability also influences the selection of the optimal site for biofuel production.

- The City of Ishpeming was identified to be the optimal site for biofuel production from forest biomass in the U.P. of Michigan for low levels of pulpwood availability (50-70\%). The Village of L'anse was identified to be the optimal site when the pulpwood availability is higher $(80-100 \%)$.

- A GIS-based approach, integrated with other mathematical models, was an efficient and practical method for identifying the optimal sites.

The utility of the two-stage site selection methodology has been demonstrated. There is little difference between location selections for a less capital-intensive power plant or a higher capital biodiesel plant because the supply chain is similar, if not the same. The methodology can also be easily applied to other regions in the U.S. With GIS it is relatively easy (the first stage of the methodology) and other data layers for different 
regions of the U.S would be required. The second stage of the methodology can be adapted to other regions of the U.S. Further studies will consider different regions of interest for forest-based biofuel production.

\section{Acknowledgments}

We are indebted to Dr. Ann Maclean for her assistance with the GIS software. We also would like to express our gratitude to Dr. Pasi Lautala and Justin Hicks for providing their insights into transportation costs. We are also grateful to Timothy Jenkins for his help during the early stages of this work. This research was supported through an agreement with the Michigan Economic Development Corporation with funding from the U.S. Department of Energy award DE-EE-0000280. This report was prepared as an account of work sponsored by an agency of the United States Government. Neither the United States Government nor any agency thereof, nor any of their employees, makes any warranty, express or implied, or assumes any legal liability or responsibility for the accuracy, completeness, or usefulness of any information, apparatus, product, or process disclosed, or represents that its use would not infringe privately owned rights. Reference herein to any specific commercial product, or service by trade name, trademark, manufactured, or otherwise does not necessarily constitute or imply its endorsement, recommendation, or favoring by the United States Government or any agency thereof. The views and opinions of authors expressed herein do not necessarily state or reflect those of the United States Government or any agency thereof.

\section{Appendix}

The GIS operation consists of the eight steps described below.

- Create a geodatabase to include all input features used for analysis;

- Join pulpwood information to counties;

- Based on the biomass available for each county, calculate the biomass density $\left(\mathrm{Mg} \mathrm{km}^{-2}\right)$ for each county;

- Join population census information to cities and villages;

- Build a $1.61 \mathrm{~km}$ (one mile) buffer around state/federal roads and railroads;

- Select cities and villages within the state/federal roads and railroads buffer;

- Select cities and villages with a census population greater than 1000;

- Transfer potential sites into point geometry (these will serve as demand points in stage II).

\section{R E F E R E N C E S}

[1] Perlack RD, Wright LL, Turhollow AF, Graham RL, Stokes BJ, Erbach DC. Biomass as feedstock for a bioenergy and bioproducts industry: the technical feasibility of a billion-ton annual supply. Oak Ridge National Laboratory, ORNL/TM-
2005/66. Available from: http://feedstockreview.ornl.gov/pdf/ billion_ton_vision.pdf; 2005 [accessed 02.08.09].

[2] Sandia National Laboratories (SNL), General Motors' R\&D Center. 90-Billion gallon biofuel deployment study: executive summary. Available from: http://www.greenbiz.com/sites/ default/files/document/Exec_Summary02-2009.pdf; 2009 [accessed 02.09.09].

[3] West T, Dunphy-Guzman K, Sun A, Malczynski L, Reichmuth D, Larson R, et al. Feasibility, economics, and environmental impact of producing 90 billion gallons of ethanol per year by 2030. Available from: http://www.sandia.gov/news/ publications/white-papers/90-Billion-GallonBiofuelSAND2009-3076J.pdf; 2009 [preprint, accessed 02.09.09].

[4] Ince PJ, Durbak I. Pulpwood supply and demand development in the south, little growth elsewhere. J For 2002; 100(2):20-5.

[5] Leightley LE. Testimony before the subcommittee on forests and forest health, committee on resources. U.S. House of Representatives. Available from: http://republicans. resourcescommittee.house.gov/UploadedFiles/testimony/ 2006/liamleightleyHTM.pdf; 2006 [accessed 02.09.09].

[6] Walsh MUS. Cellulosic biomass feedstock supplies and distribution. M\&E Biomass Publication. Available from: http://ageconsearch.umn.edu/bitstream/7625/2/U.S. \%20Biomass\%20Supplies.pdf; 2008 [accessed 02.09.09].

[7] Esnaf S, Küçükdeniz T. A fuzzy clustering-based hybrid method for a multi-facility location problem. J Intell Manuf 2009;20:259-65.

[8] Drezner Z, Wesolowsky GO. The expected value of perfect information in facility location. Oper Res 1980;28(2):395-402.

[9] Wesolowsky GO. Probabilistic weights in the one-dimensional facility location problem. Manage Sci 1977;24(2):224-9.

[10] Brimberg J, Hansen P, Mladenovic N, Taillard ED. Improvement and comparison of heuristics for solving the uncapacitated multisource Weber problem. Oper Res 2000; 48(3):444-60.

[11] Krajewski LJ, Ritzman LP, Malhotra MK. Operations management. 9th ed. Pearson Education, Inc; 2009.

[12] Cheng EWL, Li H. Exploring quantitative methods for project location selection. Build Environ 2004;39:1467-76.

[13] Kahraman C, Ruan D, Dogan I. Fuzzy group decision-making for facility location selection. Inf Sci 2003;157:135-53.

[14] Tabari M, Kaboli A, Aryanezhad MB, Shahanaghi K, Siadat A. A new method for location selection: a hybrid analysis. Appl Math Comput 2008;206:598-606.

[15] Muttiah RS, Engel BA, Jones DD. Waste disposal site selection using GIS-based simulated annealing. Comput Geosci 1996; 22:1013-7.

[16] Yeh AG-O, Chow MH. An integrated GIS and location-allocation approach to public facilities planning an example of open space planning. Comput Environ Urban 1996;20:339-50.

[17] Kallali H, Anane M, Jellali S, Tarhouni J. GIS-based multicriteria analysis for potential wastewater aquifer recharge sites. Desalination 2007;215:111-9.

[18] Zamorano M, Molero E, Hurtado Á, Grindlay A, Ramos Á. Evaluation of a municipal landfill site in Southern Spain with GIS-aided methodology. J Hazard Mater 2008;160:473-81.

[19] Ocalir EV, Ercoskun OY, Tur R. An integrated model of GIS and fuzzy logic (FMOTS) for location decisions of taxicab stands. Expert Syst Appl 2010;37:4892-901.

[20] Noorollahi Y, Itoi R, Fujii H, Tanaka T. GIS integration model for geothermal exploration and well siting. Geothermics 2008;37:107-31.

[21] Graham RL, English BC, Noon CE. A geographic information system-based modeling system for evaluating the cost of delivered energy crop feedstock. Biomass Bioenergy 2000; 18(4):309-29. 
[22] Frombo F, Minciardi R, Robba M, Rosso F, Sacile R. Planning forest biomass logistics for energy production: a strategic decision model. Biomass Bioenergy 2009;33(3):372-83.

[23] Haddad MA, Anderson PF. A GIS methodology to identify potential corn stover collection locations. Biomass Bioenergy 2008;32(12):1097-108.

[24] Voivontas D, Assimacopoulos D, Koukios EG. Assessment of biomass potential for power production: a GIS based method. Biomass Bioenergy 2001;20(2):101-12.

[25] Noon CE, Zhan FB, Graham RL. GIS-based analysis of marginal price variation with an application in the identification of candidate ethanol conversion plant locations. Network Spatial Econ 2002;2(1):79-93.

[26] Panichelli L, Gnansounou E. GIS-based approach for defining bioenergy facilities location: a case study in Northern Spain based on marginal delivery costs and resources competition between facilities. Biomass Bioenergy 2008;32(4):289-300.

[27] Zhan FB, Chen X, Noon CE, Wu G. A GIS-enabled comparison of fixed and discriminatory pricing strategies for potential switchgrass-to-ethanol conversion facilities in Alabama. Biomass Bioenergy 2005;28(3):295-306.

[28] Perpiñá C, Alfonso D, Pérez-Navarro A, Peñalvo E, Vargas C, Cárdenas R. Methodology based on geographic information systems for biomass logistics and transport optimisation. Renewable Energy 2009;34(3):555-65.

[29] Zhang F, Johnson DM, Sutherland JW. GIS-based approach of identification of the optimal pulpwood-to-biofuel facility location in Michigan's Upper Peninsula. POMS 21st Annual Conference, Vancouver Canada, May 7 to May 10, 2010.

[30] Tembo G, Epplin FM, Huhnke BL. Integrative investment appraisal of a lignocellulosic biomass-to-ethanol industry. J Agric Res Econ 2003;28(3):611-33.
[31] Department of Energy. Theoretical ethanol yield calculator. Available from: http://www1.eere.energy.gov/biomass/ ethanol_yield_calculator.html; 2006 [accessed 02.09.09].

[32] Hicks J. Modeling the multi-modal transport of logs and the effects of changing fuel prices. Master thesis. Civil and Environmental Engineering Department, Houghton, Michigan Technological University; 2009.

[33] Simpkins D. Clean energy from wood residues in Michigan. Available from: http://www.michigan.gov/documents/ wood_energy_in_michigan-final1_169999_7.pdf; 2006 [accessed 02.09.09].

[34] Van Deusen PC, Roesch FA. Alternative definitions of growth and removals and implications for forest sustainability. Forestry; 2008:176-82.

[35] MI Geographic Data Library. Available from: http://www. mcgi.state.mi.us/mgdl; [accessed 09.12.09].

[36] USDA Forest Inventory and Analysis National Program. Timber Product Output (TPO) Reports. Available from: http://srsfia2.fs fed.us/php/tpo_2009/tpo_rpa_int1.php; [accessed 10.12.09].

[37] GeoCommunicator. Available from: http://www. geocommunicator.gov/GeoComm/index.shtm; [accessed 13. 12.09].

[38] Overend RP. The average haul distance and transportation work factors for biomass delivered to a central plant. Biomass 1982;2:75-9.

[39] Jenkins BM. A comment on the optimal sizing of a biomass utilization facility under constant and variable cost scaling. Biomass Bioenergy 1997;13:1-9.

[40] Sokhansanj S, Kumar A, Turhollow AF. Development and implementation of integrated biomass supply analysis and logistics model (IBSAL). Biomass Bioenergy 2006;30:838-47.

[41] Yu Y, Bartle J, Li C-Z, Wu H. Mallee biomass as a key bioenergy source in western Australia: importance of biomass supply chain. Energy Fuels 2009;23:3290-9. 
Appendix B 
015-0479

\title{
GIS-based Approach of Identification of the Optimal Pulpwood-to-Biofuel Facility Location in Michigan's Upper Peninsula
}

\author{
Fengli Zhang \\ Department of Mechanical Engineering-Engineering Mechanics, \\ Michigan Technological University \\ 1400 Townsend Drive, Houghton, MI 49931 \\ fengliz@mtu.edu; 906-370-0537 \\ Dana M. Johnson \\ School of Business and Economics, Michigan Technological University \\ 1400 Townsend Drive, Houghton, MI 49931 \\ dana@mtu.edu; 906-487-2803 \\ John W. Sutherland \\ Division of Environmental and Ecological Engineering, Purdue University \\ 500 Central Drive, West Lafayette, IN 47907 \\ jwsuther@purdue.edu; 765-269-7265 \\ POMS 21st Annual Conference \\ Vancouver, Canada \\ May 7 to May 10, 2010
}

\begin{abstract}
One of the critical elements for promoting ethanol production from woody biomass is defining

the optimal ethanol plant location. The woody biomass feedstock and transportation costs are geographically dependent. A Geographic Information System (GIS) based approach was applied to identify potential pulpwood-to-biofuel facility locations. The approach uses a county-based
\end{abstract}


pulpwood distribution, a population census, and railroad and state/federal road transportation networks. The preferred location will be selected using a weighted-average transportation cost.

Keywords: GIS, biomass, biofuel, transportation cost, optimal facility location

\section{Introduction}

To reduce dependence on imported fossil fuels and to mitigate greenhouse gas (GHG) emissions, the United States (U.S.) is pursuing several efforts to exploit renewable biomass to produce biofuels as an alternative for transportation fuel. This is one of several possible options. The U.S.

Department of Agriculture (USDA) and the U.S. Department of Energy (DOE) Biomass

Research and Development Technical Advisory Committee members envisioned the potential of a 30\% replacement of the present consumption level of petroleum products with biofuels in the U.S. by 2030 (Perlack et al., 2005). A joint biofuels systems analysis project, “90-Billion Gallon Biofuel Deployment Study”, conducted by Sandia National Laboratories and General Motors’ Research and Development Center between March and November 2008, assessed the feasibility, implication, limitations, and enablers of large-scale production of biofuels in the U.S. Based on a series of analyses, the research teams concluded that producing 90 billion gallons of biofuels from biomass each year in the U.S. is feasible. The sensitivity analyses also demonstrated that cellulosic biofuels can compete with oil at a reasonable price based on specific assumptions 
(West et al., 2009). Forest biomass is geographically dependent and the location of a biofuel facility significantly influences the delivery cost. Selection of the best location for a processing facility becomes a critical element for cost-effective biofuel production.

A methodology using two-phases for identifying the optimal facility location for biofuel production from forest biomass was developed. Phase I used Geographic Information System (GIS) to identify potential pulpwood-to-biofuel facility locations in a study area. The GIS analysis considers such factors as a county-based pulpwood distribution, a population census, and railroad and state/federal road transportation networks. In phase II, the Public Land Survey System (PLSS) was used to generate a one-square-mile grid system as the minimum analysis unit. A weighted-average transportation cost model that utilized a transportation cost model was developed. The optimal site for biofuel production will be identified through the use of the twophase methodology.

The literature review summarizes some of the key research findings regarding the selection of the optimal plant location. Gaps in the current research have been identified and serve as the basis for the development of the proposed two-phase selection methodology. 


\section{Literature Review}

GIS is considered an effective tool to address issues related to biomass availability and cost, and issues related to bioenergy facility locations (Graham et al., 2000). Graham et al. (2000) applied GIS using a state-level modeling system for estimating regional geographic variations on energy crop feedstock costs and supplies (farmgate and delivered), and environmental effects of switching from conventional crops to energy crops. Haddad and Anderson (2008) applied GIS to identify potential supply locations of corn stover for bioenergy production. Voivontas et al. (2001) estimated the biomass potential for power production from agriculture scraps based on GIS.

Selected components of GIS have been employed to optimize biofuel production. Noon et al. (2002) proposed an algorithm for generating a marginal price (maximum delivered cost) surface and applied this methodology to identifying potential ethanol production plant locations. Panichelli and Gnansounou (2008) took into account site competition for biomass resources and developed a methodology for farmgate price calculation.

In previous research, different biomass feedstocks were used to produce biofuels and bioproducts. The most commonly used biomass feedstocks are agricultural residues (e.g., corn stover and wheat straw), energy crops (e.g., short rotation woody crops (SRWC) and 
switchgrass), and forest residues. In this study, pulpwood, which has been primarily used by paper mills, was the feedstock for biofuel production. Because of the declining demand for pulpwood by the paper products industry (Ince, 2001), this is an alternative use for a readily available woody biomass feedstock. Based on the gaps identified in the literature review, a twophase methodology was developed and will be described in the next section.

\section{Methodology}

The methodology consists of two phases of analysis: (1) identify potential pulpwood-to-biofuel facility locations based on a GIS approach (phase I), and (2) selection of the optimal biofuel facility location based on a weighted-average transportation cost model (phase II). Figure 1 outlines the steps in each phase and shows the relationship between the two phases. 

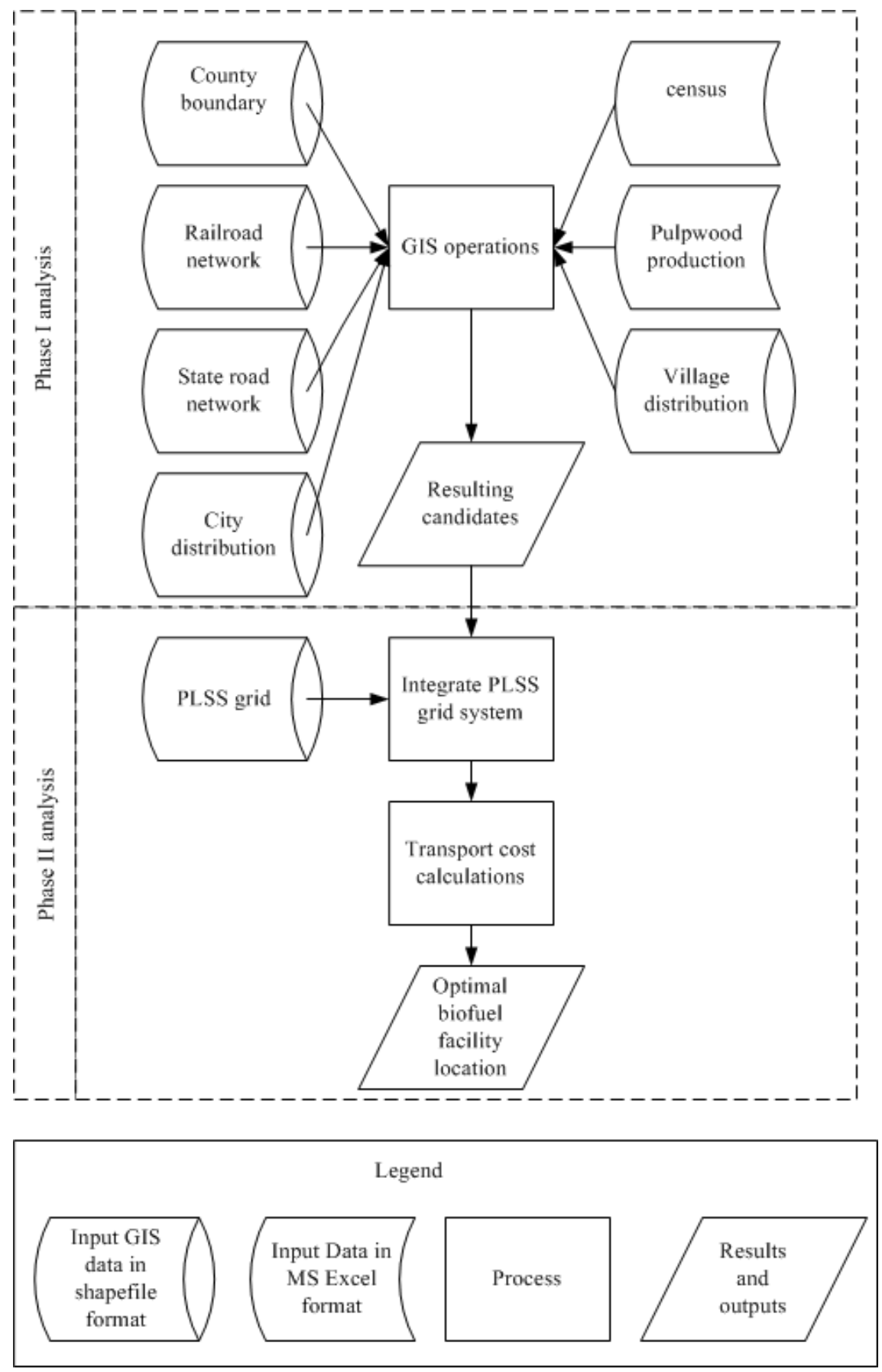

Figure 1 Overview of methodology 


\section{GIS Identification of Potential Locations for Pulpwood-to-Biofuel Facilities}

In phase I (Figure 1), GIS is used to identify potential pulpwood-to-biofuel facility locations. The required data for the GIS analysis included seven categories: county boundary, railroad transportation network, state/federal road transportation network, city distribution, village distribution, population census, and pulpwood production.

Prior to analysis, it is necessary to make several assumptions regarding the application of GIS:

- The unit of measure of pulpwood is commonly in million cubic feet. A conversion factor of $30 \mathrm{lb}$ per cubic feet is used.

- Only one percent of pulpwood production is available for biofuel production. The one percent assumption of pulpwood used for biofuel production is based on the consideration of sustainable harvesting of forest resources and competition for the raw material from other biofuel and bioproducts industries and the pulp and paper industries.

- Because the pulpwood production information is county-based, a uniform distribution was used to describe pulpwood production within each county.

- The biomass conversion plant has a medium capacity production of 50 million gallons of biofuel per year (Tembo et al., 2003). 
- Based on a conversion yield of 80 gallons/dry ton of biomass (Aden et al., 2002), the biofuel facility will have a demand for approximately 700,000 dry tons of feedstock per year.

- The trucking distance (haul radius) is 50 miles or less, with the biofuel facility location at the center of the biomass harvesting area.

- The biofuel facility is accessible to state/federal road or railroad transportation networks (i.e., the facility is within one mile of a network). This guarantees the input (pulpwood feedstock) and output (biofuel products) can be easily transported.

- The biofuel facility will be located in a city or village with a population greater than 1,000 to ensure that enough workers are available for the plant.

After the assumptions were made, the GIS operations involved in identification of potential locations for pulpwood-to-biofuel facilities are detailed. GIS operations are the central part of the methodology of the first phase of the analysis. The operations consist of the 7 steps described below.

1) Create a geodatabase to include all input features used for analysis;

2) Join pulpwood information to counties;

3) Calculate tons per square mile within each county; 
4) Join population census information to cities and villages;

5) Build a one-mile buffer around state/federal roads and railroads;

6) Select cities and villages within the state/federal roads and railroads buffer;

7) Select cities and villages with a census population greater than 1,000.

After completing the phase I analysis, additional information is available to complete phase II of analysis.

\section{Determining the Optimal Biofuel Facility Location}

The objective of phase II (Figure 1) of analysis is to identify the best location for biofuel production from forest biomass. A preliminary selection of potential sites was performed in phase I based on the GIS approach by examining a series of decision factors. Potential sites identified from phase I, including cities and villages, were transferred into point geometry that represent demand points. The $\operatorname{PLSS}^{1}$ grid system (1 mile $\mathrm{x} 1$ mile) was used as the minimum information unit over the study area. A weighted-average transportation cost model was

\footnotetext{
${ }^{1}$ PLSS was developed by the Land Ordinance of 1785 and is a method used in U.S. to survey and identify land. Its basic units of area are the township and section. The PLSS typically divides land into 6-mile-square townships. Townships are subdivided into 36 one-mile-square sections.
} 
developed. The optimal site for biofuel production from forest biomass was identified to be the one with the minimum weighted-average transportation cost.

\section{Transportation Cost Model}

The transportation cost model used for the analysis was developed by Hicks et al. (2009). Three companies from Michigan were investigated for their tariff rate structures and used to develop the model for the Upper Peninsula (U.P.) of Michigan. All of the U.P. tariff rates were converted to dollars per ton and plotted against transportation distance. Linear regression was used to fit a line to the U.P. tariff rate data. Equation Error! Reference source not found. provides the transportation $\operatorname{cost} \mathrm{C}_{\mathrm{T}}$, in dollars per mile per ton:

$C_{\mathrm{T}}=3.89+0.067 * \mathrm{~d}+0.01 .14 *\left(\mathrm{C}_{\mathrm{F}}-2.67\right) * \mathrm{~d}$

where $\mathrm{C}_{\mathrm{T}}$ is the one-way transportation cost (\$/ton) from a supply point to a demand point, $\mathrm{d}$ is the one-way transportation distance (miles) from a supply point to a demand point, and $\mathrm{C}_{\mathrm{F}}$ is the fuel price (\$/gallon). The coefficient of determination for the fitted line was $\mathrm{R}^{2}=0.9703$. The equation consists of three components: base cost, mileage cost, and fuel cost differential. The base cost rate of $\$ 3.89 /$ ton covers the cost of loading and unloading. 
The fuel cost differential term arises because the average fuel cost of $\$ 2.67 /$ gal, as was the case in Oct 2009, will not be the case in general. If the fuel cost rate is indeed $\$ 2.67 /$ gal, the one-way transportation cost, $\mathrm{C}_{\mathrm{T}}$, simplifies to:

\section{$C_{\mathrm{T}}=3.89+0.067 * \mathrm{~d}$}

The transportation cost model was used in the section below to build the weighted-average transportation cost model.

\section{Weighted-Average Transportation Cost Model}

Candidate facility locations are referred as demand points $(\mathrm{j}=1,2,3, \ldots, \mathrm{m})$. Take one demand point for example, the 50-mile biomass harvesting area for the demand point is divided into $\mathrm{n}$ cells (the area of each cell is one square mile). A pixel is placed at the centroid of each cell, and this pixel serves as the supply point for the cell. Associated with each supply point i $(i=1,2, \ldots$, $\mathrm{N})$ is the quantity $\left(\mathrm{Q}_{\mathrm{i}}\right)$ of pulpwood available. The quantity of pulpwood $\mathrm{Q}_{\mathrm{i}}$ is calculated as:

$\mathbf{Q}_{1}=\frac{\mathbf{Q}_{\mathrm{e}} \approx \mathbf{A}_{1}}{\mathbf{A}_{\mathrm{c}}}$

where $Q_{c}$ is the total quantity of pulpwood available in a county, $A_{i}$ is the area of cell or pixel $i$, and $\mathrm{A}_{\mathrm{c}}$ is the area of a county.

The Euclidean distance is calculated between any pair of supply and demand points and used as the distance in the transportation cost model. A per unit transportation cost $\mathrm{C}_{\mathrm{ij}}$ is calculated using 
the transportation cost equations. The transportation costs are sorted from the lowest to the highest. The available quantity of biomass $\mathrm{Q}_{\mathrm{i}}$ at each supply point is summed $\left(\mathrm{S}_{\mathrm{j}}\right)$ beginning with the lowest transportation cost until the sum meets or exceeds 700,000 tons. When this condition is met, $D_{j}$ is set equal to $S_{j}$ (Equation (2)).

$D_{1}=s_{1}=\sum_{i=1}^{\mathrm{n}} \mathrm{Q}_{\mathrm{i}}$

where $\mathrm{Q}_{\mathrm{i}}$ is the available quantity of biomass at each supply point, $\mathrm{S}_{\mathrm{j}}$ is the total quantity biomass available from the $n$ supply points, and $D_{j}$ is of the amount of biomass feedstock required at each demand point. The weighted-average transportation $\operatorname{cost} \mathrm{C}_{\text {avg }}(\mathrm{j})$ is calculated in Equation Error! Reference source not found., i.e., the transportation cost is weighted by the available biomass at each supply point.

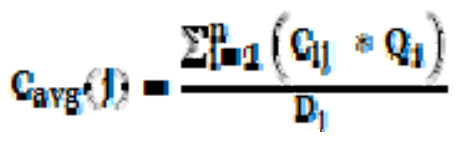

where $\mathrm{C}_{\mathrm{ij}}$ is per unit transportation cost $(\$ /$ ton $)$ and $\mathrm{C}_{\mathrm{avg}}(\mathrm{j})$ is weighted-average transportation $\operatorname{cost}(\$ /$ ton).

The weighted-average transportation distance, $\mathrm{L}_{\mathrm{avg}}(\mathrm{j})$, is calculated in Equation (4):

$$
\mathrm{L}_{\operatorname{avg}}(i)=\frac{\sum_{\mathrm{P}_{1}}\left(\mathrm{~L}_{\mathrm{L}_{1}} * \mathrm{Q}_{1}\right)}{\mathrm{D}_{1}}
$$


where $\mathrm{L}_{\mathrm{ij}}$ is the Euclidean distance between any supply point $\mathrm{i}$ and any candidate facility location j.

\section{Summary and Conclusions}

A two-phase methodology to identify the optimal facility location for biofuel production from forest biomass was developed. Phase I used GIS to identify potential pulpwood-to-biofuel facility locations in a study area. The GIS analysis considers such factors as a county-based pulpwood distribution, a population census, and railroad and state/federal road transportation networks. In phase II, the PLSS was used to generate the one-square-mile grid system as the minimum analysis unit. A weighted-average transportation cost model was developed. The optimal site for biofuel production will be identified as the one with the minimum weightedaverage transportation cost.

\section{Further Research}

The methodology developed in this study will be applied in a case study: Michigan's Upper

Peninsula, to identify the best location for biofuel production from forest biomass. Different types of sensitivity analysis will be conducted to identify the impacts of different parameters on the results, especially to identify the parameters that most influence the decision. 


\section{Acknowledgment}

This study was funded by Forestry Biofuels Statewide Collaboration Center (FBSCC), Michigan

Technological University, USA. We are indebted to Dr. Ann Maclean for her assistance with the

GIS software. We also would like to express our gratitude to Dr. Pasi Lautala and Justin Hicks

for providing their help on transportation costs. We are also grateful to Timothy Jenkins for his

help during the early phases of this work.

\section{References}

Aden A, Ruth M, Ibsen K, Jechura J, Neeves K, Sheehan J, Wallace B, Montague L, Slayton A, Lukas J. Lignocellulosic Biomass to Ethanol Process Design and Economics Utilizing Co-Current Dilute. Acid Prehydrolysis and Enzymatic Hydrolysis for Corn Stover NREL Technical Report, National Renewable Energy Laboratory 2002;154pp.

Graham RL, English BC, Noon CE. A Geographic Information System-based modeling system for evaluating the cost of delivered energy crop feedstock. Biomass and Bioenergy 2000;18(4):309-329.

Haddad MA, Anderson PF. A GIS methodology to identify potential corn stover collection locations. Biomass and Bioenergy 2008;32(12):1097-1108.

Hicks J. Modeling the Multi-Modal Transport of Logs and the Effects of Changing Fuel Prices Civil and Environmental Engineering Department. Houghton, Michigan Technological University. Master Thesis 2009;76pp.

Ince PJ. Outlook for Sustainable Fiber Supply through Forest Management and Other Developments in the U.S. Pulp and Paper Sector. International Environmental, Health \& Safety Conference and Exhibit 2001. 
Noon CE, Zhan FB, Graham RL. GIS-Based Analysis of Marginal Price Variation with an Application in the Identification of Candidate Ethanol Conversion Plant Locations. Networks and Spatial Economics 2002;2(1):79-93.

Panichelli L, Gnansounou E. GIS-based approach for defining bioenergy facilities location: A case study in Northern Spain based on marginal delivery costs and resources competition between facilities. Biomass and Bioenergy 2008;32(4):289-300.

Perlack RD, Wright LL, Turhollow AF, Graham RL, Stokes BJ, Erbach DC. Biomass as Feedstock for a Bioenergy and Bioproducts Industry: The Technical Feasibility of a Billion-Ton Annual Supply. 2005;78pp.

Tembo G, Epplin FM, Huhnke BL. Integrative Investment Appraisal of a Lignocellulosic Biomass-to-Ethanol Industry. Journal of Agricultural and Resource Economics 2003;28(3):611-633.

Voivontas D, Assimacopoulos D, Koukios EG. Assessment of biomass potential for power production: a GIS based method. Biomass and Bioenergy 2001;20(2):101-112.

West T, Dunphy-Guzman K, Sun A, Malczynski L, Reichmuth D, Larson R, Ellison J, Taylor R, Tidwell V, Klebanoff L, Hough P, Lutz A, Shaddix C, Brinkman N, Wheeler C, O’Toole D. Feasibility, economics, and environmental impact of producing 90 billion gallons of ethanol per year by 2030. 2009. 
Appendix C 


\title{
020-0387
}

\section{Comparative Analysis of Life Cycle Greenhouse Gas Emissions of Supply Chains for Biofuel and Fossil Fuel Production}

\author{
Fengli Zhang \\ Department of Mechanical Engineering-Engineering Mechanics, \\ Michigan Technological University \\ 1400 Townsend Drive, Houghton, MI 49931 \\ fengliz@ mtu.edu; 906-370-8396 \\ Robert Handler \\ Sustainable Futures Institute, Michigan Technological University \\ 1400 Townsend Drive, Houghton, MI 49931 \\ rhandler@mtu.edu; 906-487-1092 \\ Dana M. Johnson \\ School of Business and Economics, Michigan Technological University \\ 1400 Townsend Drive, Houghton, MI 49931 \\ dana@mtu.edu; 906-487-2803 \\ David R. Shonnard \\ Department of Chemical Engineering, Michigan Technological University \\ 1400 Townsend Drive, Houghton, MI 49931 \\ drshonna@mtu.edu; 906-487-3468 \\ $22^{\text {nd }}$ Annual POMS Conference \\ Reno, Nevada \\ April 29 to May 2, 2011
}

\begin{abstract}
To reduce U.S. dependence on imported oil and to reduce carbon emissions, renewable biofuel production from biomass has seen emerging interest. This study focused on life cycle greenhouse gas emission impacts of forest biomass supply chain for ethanol production. The life cycle stages considered include biomass harvesting/forwarding, and transportation via truck/rail. The comparison system is a supply chain for petroleumbased fuel production, exemplified using data specific to the U.S. The results show that from feedstock supply perspective, biofuel production from forest biomass is more environmentally friendly (about 50-70\% less greenhouse gas emissions) compared with
\end{abstract}


petroleum based fuel production. Forest biomass supply by rail performs better (about 15 million kg less carbon emissions) than truck supply.

Keywords: LCA, biomass supply chain, greenhouse gas emissions

\section{Introduction}

In recent years the U.S. has imported slightly more than one-half of its oil needs from foreign sources [1]. Such a high dependence increases U.S. strategic vulnerability and prompts more research on renewable energy production. Production of ethanol from renewable biomass, which could be a substitute for gasoline, has seen increased interest. A general assumption applied to biofuels is the carbon neutrality assumption that would underestimate greenhouse gas (GHG) impact/carbon footprint of the products. Carbon emissions are not considered across the biomass feedstock supply chain while the emissions are not insignificant [2].

To evaluate the environmental impacts associated with biofuels production and identify any opportunity for environmental improvement, Life Cycle Assessment (LCA) has proven to be an effective method [3-4] but few LCA studies on second-generation biofuels are currently available. Slade et al. [5] evaluated the GHG emissions performance of cellulosic ethanol supply chains in Europe. Blottnitz and Curran [6] reviewed the assessments conducted on bio-ethanol as a transportation fuel from a net energy, GHG, and environmental life cycle perspective. However, many uncertainties, such as the type of biomass, regional differences, transportation modes, and system boundaries, are involved in the application of LCA method which results in wide variation in the outcomes [2]. This study focused on life cycle greenhouse gas emissions of regional forest biomass feedstock supply systems for ethanol production. The 
components of the supply chain include biomass harvesting/forwarding, and transportation via truck/rail. The comparison system is a supply chain for petroleumbased fuel production in U.S. refineries, including life cycle stages of crude oil mix extraction/processing within exporting countries, crude oil mix transport within exporting countries via pipeline, crude oil mix ocean transport to domestic ports via tanker, and crude oil mix domestic transport via pipeline.

\section{LCA Methodology and Data}

\section{Functional Unit}

Due to the low energy content of ethanol, 1.5 gallons of ethanol has the energy equivalent $(120 \mathrm{MJ})$ of 1 gallon of gasoline [7]. The function unit is defined as the energy (4 PJ) that 50 million gallons of ethanol can provide. For gasoline, 33.3 (50/1.5) million gallons of gasoline are needed to provide the same amount of energy (4 PJ). The lifetime is one year. To produce ethanol 50 million gallons per year (MGY), one million green tons of forest biomass are needed by considering a conversion factor of 50 gallons of biofuel per green ton of biomass. To produce 33.3 MGY of gasoline 1.71 million barrels (71.79 million gallons) of crude oil mix are needed by assuming 19.5 gallons of gasoline can be refined from one barrel of crude oil mix which is 42 US gallons. Other project assumptions are listed below.

- Logs are used as biomass feedstock for biofuel production due to their abundance in the study area of Michigan;

- For a biorefinery producing $50 \mathrm{MGY}$ of ethanol, daily demand for biomass feedstock is about 2,860 green tons. This assumes the biorefinery operates 350 days (50 weeks) per year with 2 weeks for maintenance; 
- Biomass feedstock delivered by diesel truck or diesel railcars with an average oneway transportation distance of 67 miles ( $2 / 3$ of 100 miles radius following Overend's approach to calculate the average haul distance [8]);

- Trucks/railcars return 67 miles to harvesting areas carrying an empty load;

- With the railway supply system, 10 miles (20 miles for a round trip) of truck transportation is required to deliver biomass from landings to rail spurs;

- Truck capacity is 45 tons while railcar capacity is 80 tons with 36 railcars per shipment;

- About 72 trucks are needed each day while only one rail shipment is needed to deliver the same amount of biomass;

- Trucks have a lifetime of 10 years while the locomotive and railcars have a lifetime of 22 years;

- The moisture content is constant throughout the supply chain at 50\%;

- No dry matter loss is taken into account through the supply chain; and

- All environment loads are assigned to the main product (ethanol); no allocation is conducted.

\section{Data Tables and Sources}

Data regarding GHG emissions associated with biomass harvesting/forwarding, and transportation activities were collected from various sources. GHG emissions associated with machine construction, maintenance and replacing capital equipment are also considered. Tables 1 and 2 show GHG emissions factors and input data for forest biomass harvesting and transportation, respectively. The energy intensities required to extract/process, and transport crude oil to the U.S. are illustrated in Tables 3 and 4. 


\begin{tabular}{|c|c|c|}
\hline Item & Data & Source \\
\hline \multicolumn{3}{|l|}{ Harvesting } \\
\hline Gallons diesel / hr & $19 \mathrm{~L} / \mathrm{hr}$, full processor & White 2005 [9] \\
\hline Productivity / hr & 4 cords/hr, 2.35 tons/cord & Logger interviews [10] \\
\hline $\begin{array}{l}\text { Diesel emissions } \\
\text { factor }\end{array}$ & $13.63 \mathrm{~kg} \mathrm{GHGs} / \mathrm{gal}$ & $\begin{array}{l}\text { GREET upstream } \\
\text { production [11] + } \\
\text { US LCI combustion [12] }\end{array}$ \\
\hline $\begin{array}{l}\text { Emissions for } \\
\text { machine production, } \\
\text { maintenance }\end{array}$ & $\begin{array}{l}41,873 \mathrm{~kg} \text { GHGs production } \\
50 \% \text { addition for lifetime repairs } \\
\text { Normalized to } 160,000 \text { lifetime green } \\
\text { tons }\end{array}$ & $\begin{array}{l}\text { Athanadiassis } 2002[13] \\
\text { (based on forwarder) } \\
\text { Assumed repair, lifetime } \\
\text { production }\end{array}$ \\
\hline $\begin{array}{l}\text { Lifetime use of oils, } \\
\text { lubricants }\end{array}$ & $\begin{array}{l}4 \% \text { of lifetime fuel use } \\
14,000 \text { lifetime operating hours }\end{array}$ & $\begin{array}{l}\text { Klvac } 2003[14] \\
\text { Assumed lifetime operation }\end{array}$ \\
\hline $\begin{array}{l}\text { Oil, lubricant } \\
\text { emissions factor }\end{array}$ & $261 \mathrm{~g} \mathrm{GHGs} / \mathrm{L}$ & Athanadiassis 2000 [15] \\
\hline \multicolumn{3}{|l|}{ Forwarding } \\
\hline Gallons diesel / hr & $11 \mathrm{~L} / \mathrm{hr}$, bunk forwarder & White 2005 [9] \\
\hline Productivity / hr & 4 cords/hr, 2.35 tons/cord & Logger interviews [10] \\
\hline $\begin{array}{l}\text { Diesel emissions } \\
\text { factor }\end{array}$ & $13.63 \mathrm{~kg} \mathrm{GHGs} / \mathrm{gal}$ & $\begin{array}{l}\text { GREET upstream } \\
\text { production [11] + } \\
\text { US LCI combustion [12] }\end{array}$ \\
\hline $\begin{array}{l}\text { Emissions for } \\
\text { machine production, } \\
\text { maintenance }\end{array}$ & $\begin{array}{l}41,873 \mathrm{~kg} \text { GHGs production } \\
50 \% \text { addition for lifetime repairs } \\
\text { Normalized to } 160,000 \text { lifetime green } \\
\text { tons }\end{array}$ & $\begin{array}{l}\text { Athanadiassis } 2002[13] \\
\text { Assumed repair, lifetime } \\
\text { production }\end{array}$ \\
\hline $\begin{array}{l}\text { Lifetime use of oils, } \\
\text { lubricants }\end{array}$ & $\begin{array}{l}3 \% \text { of lifetime fuel use } \\
14,000 \text { lifetime operating hours }\end{array}$ & $\begin{array}{l}\text { Klvac } 2003[14] \\
\text { Assumed lifetime operation }\end{array}$ \\
\hline $\begin{array}{l}\text { Oil, lubricant } \\
\text { emissions factor }\end{array}$ & 261 g GHGs / L & Athanadiassis 2000 [15] \\
\hline $\begin{array}{c}\text { Total } \\
\text { GHGs / green ton } \\
\text { (Harv. \& Forw.) } \\
\end{array}$ & $\begin{array}{l}\text { 12.26 kg GHGs / Green ton } \\
\text { 6.6\% due to non-operational factors }\end{array}$ & \\
\hline
\end{tabular}

Table 1 Data and assumptions for roundwood harvesting/forwarding 


\begin{tabular}{|c|c|c|}
\hline Item & Data & Source \\
\hline \multicolumn{3}{|l|}{ Truck transportation } \\
\hline $\begin{array}{l}\text { Diesel emissions } \\
\text { factor }\end{array}$ & $13.63 \mathrm{~kg} \mathrm{GHGs} / \mathrm{gal}$ & $\begin{array}{l}\text { GREET upstream } \\
\text { production [11] + } \\
\text { US LCI combustion [12] }\end{array}$ \\
\hline $\begin{array}{l}\text { Log truck fuel use per } \\
\text { ton-mile }\end{array}$ & $\begin{array}{l}3.61 \text { miles / gallon } \\
45 \text { ton loaded average } \\
50 \% \text { loaded miles } \\
0.0123 \text { gal / ton-mile }\end{array}$ & Logger interviews [10] \\
\hline $\begin{array}{l}\text { Emissions for log } \\
\text { truck production, } \\
\text { maintenance }\end{array}$ & $55,400 \mathrm{~kg}$ GHGs & $\begin{array}{l}\text { Ecoinvent database for } 40-\mathrm{t} \\
\text { lorry production, } \\
\text { maintenance [16] }\end{array}$ \\
\hline $\begin{array}{l}\text { Lifetime ton-miles of } \\
\text { log truck }\end{array}$ & $\begin{array}{l}10 \text { yr productive life } \\
75,000 \text { miles / yr } \\
45 \text { ton loads, } 50 \% \text { loaded miles }\end{array}$ & $\begin{array}{l}\text { Interviews with forest } \\
\text { products industry workers }\end{array}$ \\
\hline $\begin{array}{l}\text { Total Log Truck } \\
\text { GHGs / ton-mile }\end{array}$ & $\begin{array}{l}0.171 \mathrm{~kg} \text { GHGS/ ton-mile } \\
1.75 \% \text { non-operational factors }\end{array}$ & \\
\hline \multicolumn{3}{|l|}{ Rail transportation } \\
\hline $\begin{array}{l}\text { Diesel emissions } \\
\text { factor }\end{array}$ & $13.63 \mathrm{~kg} \mathrm{GHGs} / \mathrm{gal}$ & $\begin{array}{l}\text { GREET upstream } \\
\text { production [11] }+ \\
\text { US LCI combustion [12] }\end{array}$ \\
\hline $\begin{array}{l}\text { Rail emissions factor } \\
\text { per ton-mile }\end{array}$ & $0.0015 \mathrm{~kg}$ GHGs / ton-mile & CN Railroad [17] \\
\hline $\begin{array}{l}\text { Emissions for rail } \\
\text { equipment production, } \\
\text { maintenance }\end{array}$ & $2,537,000 \mathrm{~kg} \mathrm{GHGs}$ & $\begin{array}{l}\text { Ecoinvent database for } \\
\text { long-distance train } \\
\text { production, maintenance, } \\
\text { no rail lines included [16] }\end{array}$ \\
\hline $\begin{array}{l}\text { Lifetime ton-miles of } \\
\text { rail equipment }\end{array}$ & $\begin{array}{l}20,000,000 \text { lifetime miles } \\
2,000 \text { tons loaded }\end{array}$ & Assumed values \\
\hline $\begin{array}{l}\text { Total Rail } \\
\text { GHGs / ton-mile }\end{array}$ & $\begin{array}{l}0.0345 \mathrm{~kg} \text { GHGS/ ton-mile } \\
0.17 \% \text { non-operational factors }\end{array}$ & \\
\hline
\end{tabular}

Table 2 Data and assumptions for truck and rail transportation 


\begin{tabular}{|l|l|l|l|l|}
\hline Life Cycle Stage & $\begin{array}{l}\text { Fuel } \\
\text { Source }\end{array}$ & $\begin{array}{l}\text { Energy } \\
\text { Intensity }\end{array}$ & Unit & Data Source \\
\hline $\begin{array}{l}\text { Transport Within } \\
\text { Exporting Countries via } \\
\text { Pipeline }\end{array}$ & Electricity & 260 & Btu/ton-mile & $\begin{array}{l}\text { DOE/NETL } \\
\text { report[18] }\end{array}$ \\
\hline $\begin{array}{l}\text { Ocean Transport To } \\
\text { Domestic Ports via Tanker }\end{array}$ & $\begin{array}{l}\text { Heavy } \\
\text { Fuel Oil }\end{array}$ & 5.5 & $\begin{array}{l}\text { Btu/bbl-nautical } \\
\text { mile }\end{array}$ & \\
\cline { 1 - 3 } $\begin{array}{l}\text { Domestic Transport via } \\
\text { Pipeline }\end{array}$ & Electricity & 12,997 & Btu HHV/bbl & \\
\hline
\end{tabular}

Table 3 Energy Intensity of Crude Oil Mix Supply Chain

\begin{tabular}{|l|l|l|l|l|}
\hline \multirow{2}{*}{ Life Cycle Stage } & \multicolumn{3}{|c|}{ Emissions (kg/bbl crude oil) } & \multirow{2}{*}{ Data Source } \\
\cline { 2 - 4 } & \multicolumn{1}{|c|}{$\mathrm{CO}_{2}$} & \multicolumn{1}{|c|}{$\mathrm{CH}_{4}$} & $\mathrm{~N}_{2} \mathrm{O}$ & \\
\hline Extraction/Processing & 23.5 & 0.525 & 0.000641 & \multirow{2}{*}{$\begin{array}{l}\text { DOE/NETL } \\
\text { report[18] }\end{array}$} \\
\hline $\begin{array}{l}\text { Transport within Exporting } \\
\text { Countries via Pipeline }\end{array}$ & 0.863 & 0.001 & 0.0000112 & \\
\cline { 1 - 1 } $\begin{array}{l}\text { Ocean Transport to Domestic } \\
\text { Ports via Tanker }\end{array}$ & 5.54 & 0.000404 & 0.000141 & \\
\cline { 1 - 4 } $\begin{array}{l}\text { Domestic Transport via } \\
\text { Pipeline }\end{array}$ & 2.81 & 0.00327 & 0.0000365 & \\
\hline
\end{tabular}

Table 4 GHG Emissions Associated with Crude Oil Mix Supply Chain

\section{Life Cycle Diagram}

The life cycle diagram for forest biomass supply chain and crude oil supply chain are

illustrated in Figures 1 and 2. The biomass feedstock supply chain starts at forest areas to harvest logs. Then $\operatorname{logs}$ are forwarded to roadside collection points waiting for trucks. The loaded trucks transport logs either directly to a processing facility or to railway spurs for transaction. The crude oil supply system in U.S. refineries includes life cycle stages of crude oil mix extraction/processing within exporting countries, crude oil mix transport within exporting countries via pipeline, crude oil mix ocean transport to domestic ports via tanker, and crude oil mix domestic transport via pipeline. 


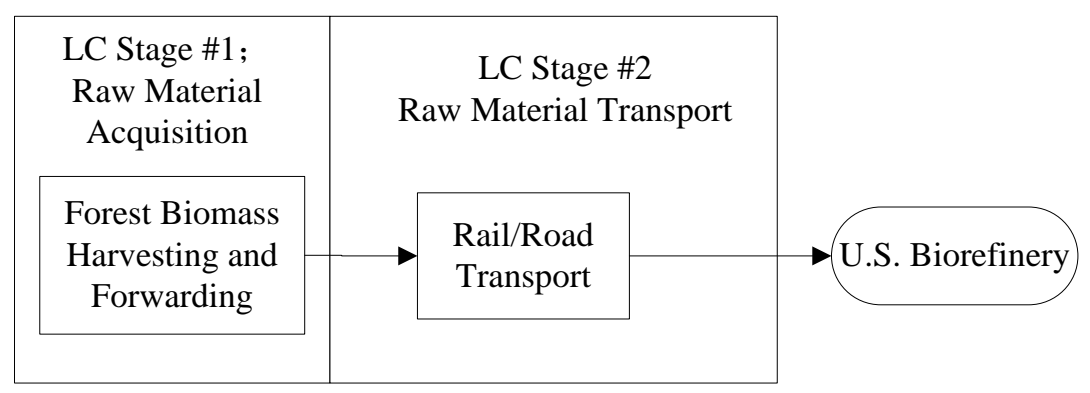

Figure 1 life cycle flow diagram of forest biomass supply chain

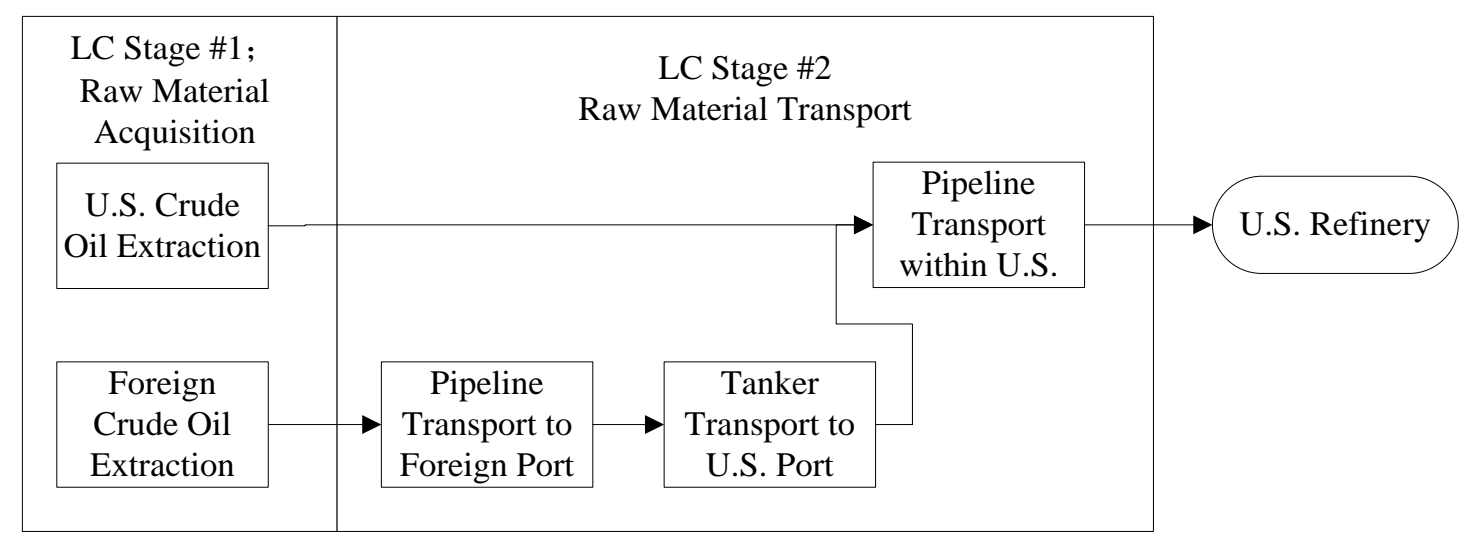

Figure 2 life cycle flow diagram of Crude Oil supply chain

\section{LCA Results and Discussion}

Based on the comparative life cycle analysis for the two supply chain systems, the results are shown in Tables 5-8. Table 5 shows the comparative results of total GHG emissions and GHG emissions per energy unit throughout the three supply chain systems. The proposed $50 \mathrm{MGY}$ biofuel facility results in the emission of $8.794 \mathrm{~g}$ by truck and $5.076 \mathrm{~g}$ by rail $\mathrm{CO}_{2}$ equivalent per megajoule $(\mathrm{MJ})$ of ethanol produced, when no co-product credits are considered. Compared to petroleum gasoline, which emits $16.773 \mathrm{~g} \mathrm{CO}_{2}$ equivalent per MJ (2005 baseline), this is a 50-70\% reduction in greenhouse gas (GHG) emissions. The forest biomass supply system by rail performs better (about 15 million $\mathrm{kg}$ less GHG emissions) than the forest biomass supply via truck. Breakdown analysis (Tables 6-8) of each supply chain system is examined to identify which life cycle stage 
accounts for the most carbon emissions. For forest biomass supply chain system via truck (Table 6), the life cycle stages of truck operations generates the most carbon footprint (64\%) while carbon emissions resulting from truck production/maintenance is less than 2\%. For forest biomass rail supply system (Table 7), carbon emissions from rail locomotive and cars operations accounts for about $40 \%$ while biomass harvesting/forwarding about $56 \%$ and emissions due to rail locomotive and cars production/maintenance is insignificant. For crude oil supply to U.S. refineries (Table 8), crude oil extraction and processing is the largest carbon emissions source (about 60\%).

\begin{tabular}{|l|l|l|}
\hline Item & million $\mathrm{kg} \mathrm{CO}_{2}$ eq & $\mathrm{g} \mathrm{CO}_{2}$ eq/MJ energy \\
\hline Biomass Supply Chain by Truck & 35.174 & 8.794 \\
\hline Biomass Supply Chain byRail & 20.303 & 5.076 \\
\hline Crude Oil Supply Chain & 67.092 & 16.773 \\
\hline
\end{tabular}

Table 5 GHG Emissions of Biomass Supply Chain and Crude Oil Supply Chain

\begin{tabular}{|l|l|l|}
\hline LC Stage & million $\mathrm{kg} \mathrm{CO}_{2} \mathrm{eq}$ & $\%$ \\
\hline Harvesting/Forwarding Operations & 11.451 & $32.55 \%$ \\
\hline $\begin{array}{l}\text { Harvesting/Forwarding Machines } \\
\text { Production /Maintenance }\end{array}$ & 0.809 & $2.30 \%$ \\
\hline Truck Operations & 22.513 & $64.00 \%$ \\
\hline Truck Production / Maintenance & 0.401 & $1.14 \%$ \\
\hline Total & 35.174 & $100 \%$ \\
\hline
\end{tabular}

Table 6 GHG Emissions of Biomass Supply Chain by Truck

\begin{tabular}{|l|l|l|}
\hline LC Stage & million $\mathrm{kg} \mathrm{CO}_{2}$ eq & $\%$ \\
\hline Harvesting/Forwarding Operations & 11.451 & $56.40 \%$ \\
\hline $\begin{array}{l}\text { Harvesting/Forwarding Machines } \\
\text { Production /Maintenance }\end{array}$ & 0.809 & $3.99 \%$ \\
\hline Rail Locomotive/Car Operations & 8.029 & $39.55 \%$ \\
\hline $\begin{array}{l}\text { Rail Locomotive/Car Production / } \\
\text { Maintenance }\end{array}$ & 0.014 & $0.07 \%$ \\
\hline Total & 20.303 & $100 \%$ \\
\hline
\end{tabular}

Table 7 GHG Emissions of Biomass Supply Chain by Rail 


\begin{tabular}{|l|l|l|}
\hline LC Stage & million $\mathrm{kg} \mathrm{CO}_{2}$ eq & $\%$ \\
\hline Crude Oil Mix Extraction/Processing & 40.185 & $59.90 \%$ \\
\hline Crude Oil Transport within Exporting Country & 3.648 & $5.44 \%$ \\
\hline Crude Oil Mix Ocean Transport to Domestic Ports & 11.369 & $16.95 \%$ \\
\hline Crude Oil Mix Domestic Transport (pipeline) & 11.889 & $17.72 \%$ \\
\hline Total & 67.092 & $100 \%$ \\
\hline
\end{tabular}

Table 8 GHG Emissions of Crude Oil Supply Chain

\section{Conclusions}

From woody biomass feedstock supply perspective, ethanol production from forest biomass is more environmentally friendly compared with petroleum-based fuel production. Research focused on improving biomass recovery efficiency will help to reduce carbon emissions further. For forest biomass supply, the rail supply system produces fewer amounts of carbon emissions compared with the truck supply system. However, to choose one supply chain system over another, additional criteria, such as system cost and the availability of rail system, should be examined. To make a reasonable decision, further investigation is required.

\section{Acknowledgements}

This research was supported through an agreement with the Michigan Economic

Development Corporation with funding from the U.S. Department of Energy award DEEE-0000280.

\section{References}

[1] Goerold, T.R.,Sources of United States Oil Supply. 2008; Available from: http://www.lookoutmtn.com/Documents/Sources_of_United_States_Oil_Supply.p df.

[2] Cherubini F., Bird N.D., Cowie A., Jungmeier G., Schlamadinger B., WoessGallasch S. Energy- and greenhouse gas-based LCA of biofuel and bioenergy systems: Key issues, ranges and recommendations. Resources, Conservation and Recycling 2009, 53: 434-447.

[3] Consoli F., Allen D., Boustead I., Fava J., Franklin W., Jensen A.A., de Oude N., Parrish R., Perriman R., Postlethwaite D., Quay B., Séguin J. and Vigon B., editors. Guidelines for life-cycle assessment: a 'Code of practice', Society of 
Environmental Toxicology and Chemistry (SETAC) (1993) [SETAC Workshop, Sesimbra, Portugal, 31 March-3 April 1993].

[4] Lindfors L.-G., Christiansen K., Hoffmann L., Virtanen Y., Juntilla V. and Hanssen O.J. et al. Nordic guidelines on Life-Cycle Assessment. Nord 1995:20. Copenhagen: Nordic Council of Ministers; 1995.

[5] Slade R., Bauen A., Shah N. The greenhouse gas emissions performance of cellulosic ethanol supply chains in Europe. Biotechnology for Biofuels 2009, 2:15.

[6] Blottnitz von H. and Curran M.A. A review of assessments conducted on bioethanol as a transportation fuel from a net energy, greenhouse gas, and environmental life cycle perspective, Journal of Cleaner Production 2007;15:607-619.

[7] Pimentel, D. Ethanol Fuels: Energy Balance, Economics, and Environmental Impacts are Negative. Natural Resources Research 2003,12:2,127-134.

[8] Overend RP. The average haul distance and transportation work factors for biomass delivered to a central plant. Biomass 1982;2:75-79.

[9] White, M.K., Gower, S.T. and Ahl, D.E. Life cycle inventories of roundwood production in northern Wisconsin: Inputs into an industrial forest carbon budget. Forest Ecology and Management, Vol. 219, 2005, 13-28.

[10] Handler, R. Personal communication and interviews with loggers in the state of Michigan. April 2010. Results currently unpublished.

[11] Wang, M. GREET 1, version 1.8c.0 - Fuel-cycle model. Argonne National Laboratory, 2009.

[12] U.S. Life-Cycle Inventory Database. 2009; Available from: www.nrel.gov/lci.

[13] Athanassiadis, D., Lidestav, G. and Nordfjell, T. Energy use and emissions due to the manufacture of a forwarder. Resources Conservation and Recycling,Vol. 34, 2002, 149-160.

[14] Klvac, R., Ward, S., Owende, P.M.O. and Lyons, J. Energy audit of wood harvesting systems. Scandinavian Journal of Forest Research, Vol. 18, 2003, 176183.

[15] Athanassiadis, D. Energy consumption and exhaust emissions in mechanized timber harvesting operations in Sweden. Science of the Total Environment, Vol. 255, 2000, 135-143.

[16] Frischknecht, R. and Rebitzer, G. The ecoinvent database system: a comprehensive web-based LCA database. Journal of Cleaner Production,Vol. 13, 2005, 1337-1343.

[17] Canadian National Railroad Greenhouse Gas Calculator Emission Factors. 2009 [cited; Available from: http://www.cn.ca/en/greenhouse-gas-calculator-emissionfactors.htm.

[18] DOE/NETL-2009/1346. Development of baseline data and analysis of life cycle greenhouse gas emissions of petroleum-based fuels. Nov 26, 2008. 
Appendix D 


\title{
Development of a Biomass Supply Chain for Biofuel Production
}

\author{
Fengli Zhang \\ Dept. of Mechanical Engineering-Engineering Mechanics, \\ Michigan Technological University \\ Houghton, MI 49931, USA \\ Dana M. Johnson \\ School of Business and Economics, Michigan Technological University \\ Houghton, MI 49931, USA \\ Mark A. Johnson \\ Dept. of Mechanical Engineering Technology, Michigan Technological University \\ Houghton, MI 49931, USA \\ John W. Sutherland \\ Division of Environmental and Ecological Engineering, Purdue University \\ West Lafayette, IN 47907, USA
}

\begin{abstract}
To reduce U.S. dependence on imported oil and reduce carbon emissions, biofuel production from renewable biomass is receiving increasing interest. However, due to the distributed nature of biomass feedstock, the cost and complexity of biomass recovery operations result in significant challenges that hinder the increased biomass utilization for energy production. This paper describes the development of a simulation model using Arena for the biomass supply chain for biofuel production in Michigan. The model describes the supply chain from landing sites to the biorefinery, including biomass harvesting, transportation, and on-site storage. The simulation model is driven by both the daily biomass production at harvesting sites distributed across a harvesting region and the daily demand for biomass feedstock at a biorefinery located in the center of the region. The supply chain model is evaluated using multiple criteria that include the delivered feedstock cost, energy consumption, and greenhouse gas (GHG) emissions. Other considerations include the average age of the in-field biomass inventory and road restrictions associated with spring thaw that limit use of truck transportation on certain roads. The utility of the supply chain simulation model is demonstrated by considering a biomass supply chain for a biorefinery in the lower peninsula of Michigan.
\end{abstract}

\section{Keywords}

Biomass supply chain, simulation, delivered feedstock cost, energy consumption, greenhouse gas emissions

\section{Introduction}

To reduce carbon emissions and reduce U.S. dependence on imported oil, renewable biofuel production from biomass has received increasing interest. However, due to the distributed nature of biomass feedstock, the cost and complexity of biomass recovery operations result in significant challenges that hinder increased biomass utilization for energy production [1, 2]. To facilitate the exploration of a wide variety of conditions that promise profitable biomass utilization, a supply chain model has been designed and implemented using Arena Simulation Software [3]. Model simulations provide a number of economic and environmental performance measures for each condition that is considered. Ultimately, it is desired to employ the simulation model to find conditions that minimize the delivered feedstock cost, energy consumption, and greenhouse gas (GHG) emissions. 
There is extensive literature focusing on biomass supply [4-9], which relates to the supply chain model developed in this study. Information from previously developed biomass supply chains formed the foundation for the development of the supply chain in this case study. The National Biofuels Plan developed by the Biomass R\&D Board focuses on biomass feedstock processing and logistics that relate to the supply chain, such as harvesting process, storage facilities, and transportation of the feedstock [4]. The biofuel plan is based on the use of agricultural residues and woody residues as biomass feedstock; for the present research, the supply chain is assumed to employ logs, which in the past were in demand by paper mills. The Idaho National Laboratory (INL) developed a uniformformat feedstock supply chain that can be implemented at a nationwide level [5-6]. This is different from the scope of a supply chain for a biofuel facility located in Michigan. The Sandia National Laboratories (SNL) developed a model that considers cellulosic ethanol from various biomass feedstock types, such as corn, agricultural residues, energy crops, and forest residues, to support the national goal of producing 90 billion gallons (341 billion liters) of biofuels each year in the U.S. by 2030 [7-8]. The Oak Ridge National Laboratory (ORNL) investigated the feasibility of expanding the ethanol industry, and specifically focused on the additional infrastructure that needs to be built [9]. Examination of this additional infrastructure requirement is beyond the scope of the present study.

\section{Simulation Model Design}

The development of a biomass feedstock supply chain for a facility considers a number of key activities and processes: biomass harvesting and forwarding to a roadside collection point, transportation from the roadside collection point to the processing facility by rail or truck, and on-site storage. Size reduction (chipping) activity is assumed to occur at the biofuel facility where the biomass can be processed most efficiently [10]. The purpose of a simulation model is to evaluate the supply chain based on multiple criteria that include the delivered feedstock cost, energy consumption, and GHG emissions. The delivered feedstock cost consists of stumpage cost (payment to loggers), loading cost, transportation cost, unloading cost, and storage cost. For the supply chain, energy use intensity and GHG emissions are assumed to only be associated with harvesting/forwarding and transportation activities. Other considerations of the model include the average age of the in-field biomass inventory and road restrictions associated with the spring thaw that limit use of truck transportation during that time.

The simulation model was built using Arena Simulation Software [3]. The model consists of four sub-models: initialization, harvesting areas, biorefinery, and daily biomass processing. The simulation model is driven by both daily demand for biomass feedstock at a biorefinery and the daily biomass recovery at harvesting sites distributed across a harvesting region (the biorefinery is located at the center of the region). In other words, it is a combined "pull" and "make-to-order" supply chain system. Each day the biorefinery requires a specified quantity of biomass feedstock from harvesting areas or on-site storage. Figure 1 illustrates the model logic. The detailed logic for each sub-model is described separately below.

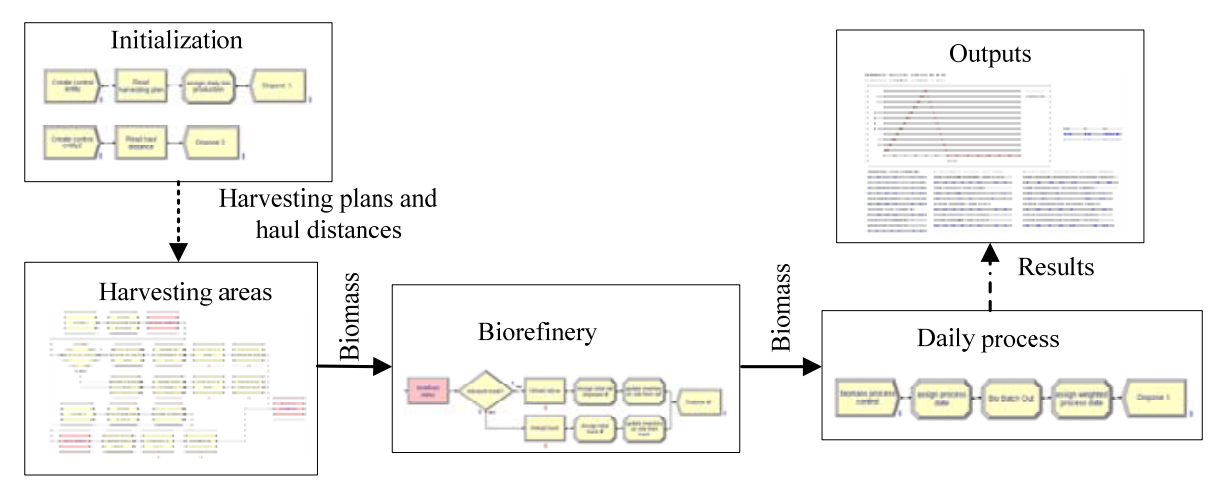

Figure 1: Logic for biomass supply chain model

\subsection{Initialization}

One of the two drivers that dictate the character of the supply chain is the daily biomass demand of the bioprocessing facility. The second is the amount of biomass that is recovered daily at all the harvesting sites. The initialization procedure (Figure 2) reads two types of data for model configuration before beginning the simulation: the daily biomass recovery (biomass harvesting plans) at the harvesting areas within a given region and transportation distances from all the harvesting areas to the biorefinery. 


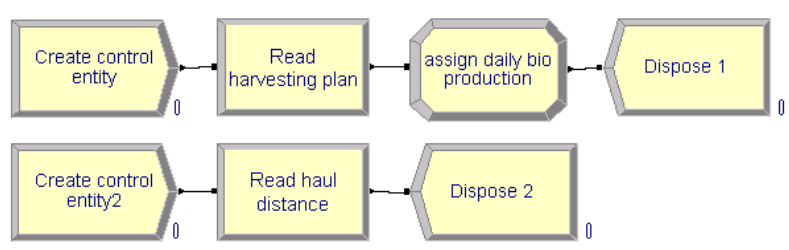

Figure 2: Sub-model design for reading harvesting plans and haul distances

\subsection{Harvesting Areas}

Harvesting areas may be placed into two categories: harvesting areas with rail access and harvesting areas without rail access. For harvesting areas with rail access, two transport modes are available: road and railway, while only truck transportation is available for areas having no rail access. The harvesting area sub-model (Figure 3) starts with the biomass located at the landing areas. Therefore, no harvesting and forwarding activities are considered. The transportation activity consists of loading transporters, transporting, and unloading transporters at the biorefinery. In Figure 3 two harvesting sites (site one has railway access and site two has no railway access) are indicated as two biomass feedstock supply locations for a biofuel facility.

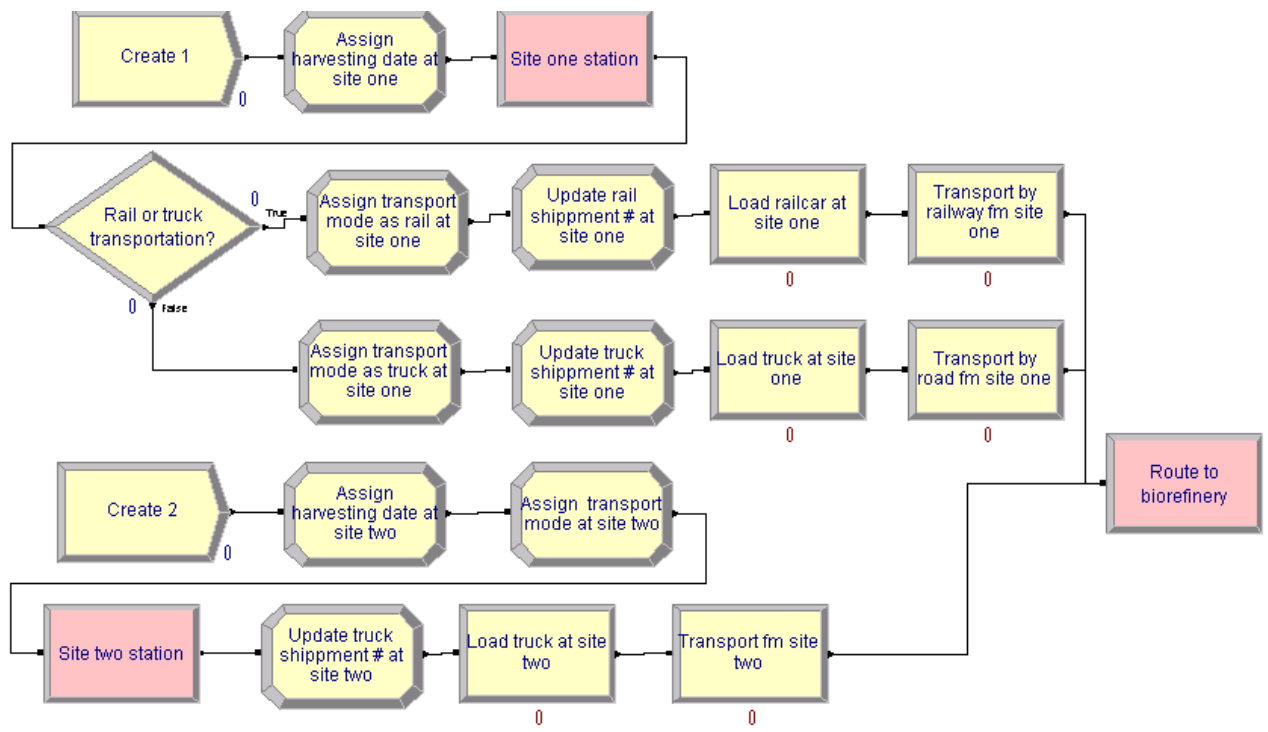

Figure 3: Sub-model design for harvesting areas

\subsection{Biorefinery}

At the biorefinery, as transporters arrive they are unloaded and the on-site inventory is updated. Total truck numbers and railcars numbers are also updated as appropriate. The sub-model logic for the biorefinery operation is shown in Figure 4.

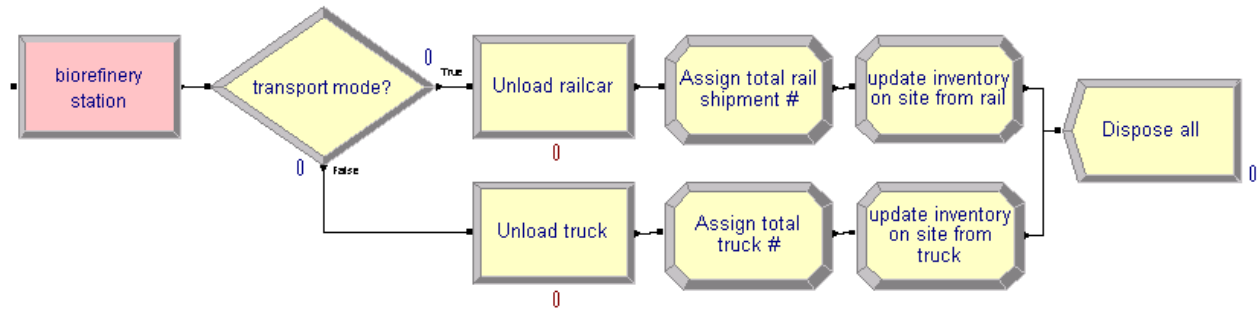

Figure 4: Sub-model design for biorefinery operations 


\subsection{Daily Biomass Processing}

As has been noted, one of the supply chain drivers that influence the model is the daily demand for biomass feedstock at a biorefinery. This biomass processing sub-model (Figure 5) is responsible for dictating the daily biomass demand at a biorefinery. Each day a production target (control entity) is issued and then the biorefinery prepares a certain amount of biomass either from the on-site inventory or using fresh biomass (biomass that is delivered to the biorefinery on the day it is needed) to process based on the daily requirement/production target. Generally, the inventory is managed using a First-In First-Out (FIFO) method. This is to ensure that the oldest biomass is processed first. After batching out, the inventory is updated and the average biomass age is also tracked to calculate the storage cost.

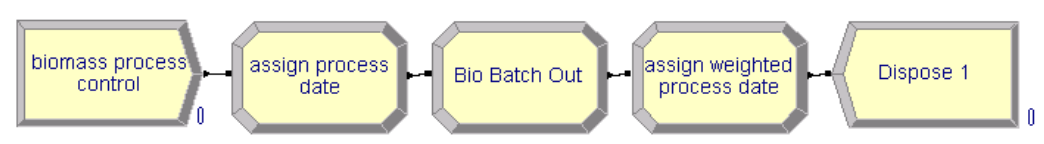

Figure 5: Sub-model design for biomass processing

\subsection{Graphical User Interface}

An easy-to-use graphical user interface has been developed for the simulation model. The interface (Figure 6) allows users to type in model parameters before running the model. The model parameters are classified into four categories: cost coefficients, energy intensity coefficients, GHG emission coefficients, and transportation coefficients.

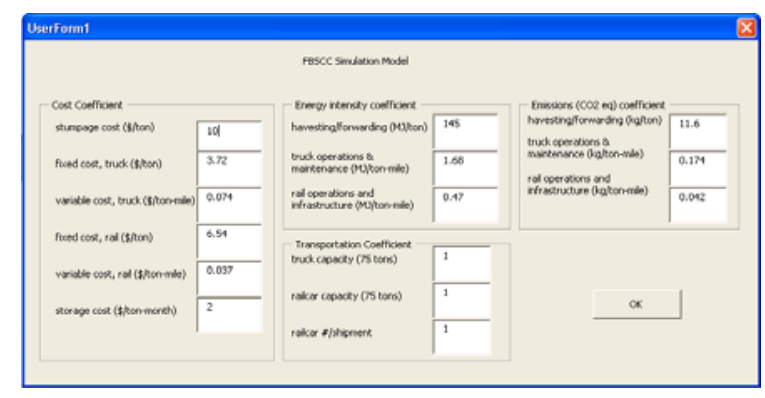

Figure 6: Graphical user interface

\section{System Performance Measures}

The previous section described a model that has been developed to simulate the supply chain for a biomass processing facility. This section discusses several measures that may be used to characterize the performance of the system, and methodologies are presented to calculate the delivered feedstock cost, energy consumption, and GHG emissions using the simulation model.

\subsection{Delivered Feedstock Cost}

The delivered feedstock cost consists of stumpage cost, loading cost, transportation cost, unloading cost, and storage cost. The stumpage cost is the payment made to loggers. The unit stumpage cost (h, $\$$ /ton) is assumed to be constant for all the harvesting areas within the study region $(\mathrm{i}=1,2, \ldots, \mathrm{I})$ in any time period $(\mathrm{t}=1,2, \ldots, \mathrm{T})$. The daily biomass recovery at harvesting area $i$ is defined as $q_{i t}$. The stumpage cost $\left(C_{h}, \$\right)$ is calculated as:

$$
\mathrm{C}_{\mathrm{h}}=\sum_{\mathrm{t}=1}^{\mathrm{T}} \sum_{\mathrm{i}=1}^{\mathrm{I}} \mathrm{h} \cdot \mathrm{q}_{\mathrm{it}}
$$

The transportation cost $\left(\mathrm{C}_{\mathrm{tr}}, \$\right)$ consists of two major terms: one for truck transportation and one for rail transportation. The truck transportation cost has a fixed cost $\left(\mathrm{t}_{\mathrm{lu}}, \$ / \mathrm{ton}\right.$, which includes one loading and unloading routine) and a variable (distance-dependent) cost ( $\mathrm{t}_{\mathrm{d}}, \$$ /ton-mile). The rail transportation cost also has a fixed cost $\left(\mathrm{r}_{\mathrm{lu}}\right.$, $\$ /$ ton, which includes one loading and unloading routine) and a variable (distance-dependent) cost ( $\mathrm{r}_{\mathrm{d}}$, \$/ton-mile). The transportation cost is calculated as: 


$$
\mathrm{C}_{\mathrm{tr}}=\sum_{\mathrm{t}=1}^{\mathrm{T}} \sum_{\mathrm{i}=1}^{\mathrm{I}}\left[\left(\mathrm{t}_{\mathrm{lu}}+\mathrm{t}_{\mathrm{d}} \cdot \mathrm{d}_{\mathrm{i}}\right) \cdot \alpha+\left(\mathrm{r}_{\mathrm{lu}}+\mathrm{r}_{\mathrm{d}} \cdot \mathrm{d}_{\mathrm{i}}\right) \cdot(1-\alpha)\right] \cdot \mathrm{q}_{\mathrm{it}}
$$

where $d_{i}$ is the transportation distance from harvesting area $i$ to the biorefinery and $\alpha$ is the percentage of biomass that is transported by truck.

For northern climates with snow and ice, there is a need to have extra inventory on hand at the biofuel facility, since roads are closed during the period of spring breakup. The cost or storing this inventory is determined by the spring breakup duration $\left(\mathrm{D}_{\mathrm{sb}}\right)$, daily feedstock demand (Cap) at a biorefinery, and the time $\left(\mathrm{D}_{\mathrm{p}}\right)$ it takes to build up the onsite inventory from which the biorefinery consumes biomass feedstock during spring breakup. The unit storage cost, $\mathrm{s}$, is expressed in \$/ton-month. It is assumed that there are 30 days in a month. The storage cost $\left(\mathrm{C}_{\mathrm{s}}, \$\right)$ is calculated as:

$$
\mathrm{C}_{\mathrm{s}}=\frac{\mathrm{D}_{\mathrm{sb}} \cdot \mathrm{Cap} \cdot\left(\mathrm{D}_{\mathrm{p}}+\mathrm{D}_{\mathrm{sb}}\right)}{2} \cdot \frac{\mathrm{s}}{30}
$$

The overall delivered feedstock cost $\left(\mathrm{C}_{\mathrm{all}}, \$\right)$ is the sum of stumpage cost, transportation cost, and storage cost. The calculation is

$$
\mathrm{C}_{\mathrm{all}}=\mathrm{C}_{\mathrm{h}}+\mathrm{C}_{\mathrm{tr}}+\mathrm{C}_{\mathrm{s}}
$$

\subsection{Energy Consumption}

Energy consumption (MJ) is assumed to only be associated with harvesting/forwarding and transportation activities. The energy consumed per unit of biomass (MJ/ton) for harvesting/forwarding is termed $f_{h}$, $f_{\text {truck }}$ is the truck transportation energy intensity (MJ/ton-mile), and $\mathrm{f}_{\text {rail }}$ is the rail transportation energy intensity (MJ/ton-mile). The energy used in harvesting/forwarding $\left(\mathrm{F}_{\mathrm{h}}, \mathrm{MJ}\right)$ is calculated as:

$$
\mathrm{F}_{\mathrm{h}}=\sum_{\mathrm{t}=1}^{\mathrm{T}} \sum_{\mathrm{i}=1}^{\mathrm{I}} \mathrm{f}_{\mathrm{h}} \cdot \mathrm{q}_{\mathrm{it}}
$$

Transportation energy consumption $\left(\mathrm{F}_{\mathrm{tr}}, \mathrm{MJ}\right)$ for truck/rail is calculated as:

$$
F_{\text {tr }}=\sum_{\mathrm{t}=1}^{\mathrm{T}} \sum_{\mathrm{i}=1}^{\mathrm{I}}\left[\mathrm{f}_{\text {truck }} \cdot \alpha+\mathrm{f}_{\text {rail }} \cdot(1-\alpha)\right] \cdot \mathrm{d}_{\mathrm{i}} \cdot \mathrm{q}_{\text {it }}
$$

The overall energy consumption ( $F_{\text {all }}, \mathrm{MJ}$ ) is the sum of energy use associated with harvesting/forwarding, and transportation, and is given by Equation (7):

$$
\mathrm{F}_{\mathrm{all}}=\mathrm{F}_{\mathrm{h}}+\mathrm{F}_{\mathrm{tr}}
$$

\subsection{GHG Emissions}

In terms of the processes that deliver biomass to a processing facility, GHG emissions (kg) are assumed to only be associated with harvesting/forwarding and transportation activities. $\mathrm{w}_{\mathrm{h}}$ is the GHG emissions per unit of biomass ( $\mathrm{kg} / \mathrm{ton})$ for harvesting/forwarding and $\mathrm{w}_{\text {truck }}$ is the truck transportation GHG emission intensity (kg/ton-mile) and $\mathrm{W}_{\text {rail }}$ is the rail transportation GHG emission intensity (kg/ton-mile). GHG emissions ( $\mathrm{W}_{\mathrm{h}}$, $\mathrm{kg}$ ) associated with harvesting/forwarding are then calculated as:

$$
\mathrm{W}_{\mathrm{h}}=\sum_{\mathrm{t}=1}^{\mathrm{T}} \sum_{\mathrm{i}=1}^{\mathrm{I}} \mathrm{w}_{\mathrm{h}} \cdot \mathrm{q}_{\mathrm{it}}
$$

And, the GHG emissions $\left(\mathrm{W}_{\mathrm{tr}}, \mathrm{kg}\right)$ associated with transportation are

$$
\mathrm{W}_{\mathrm{tr}}=\sum_{\mathrm{t}=1}^{\mathrm{T}} \sum_{\mathrm{i}=1}^{\mathrm{I}}\left[\mathrm{w}_{\text {truck }} \cdot \alpha+\mathrm{w}_{\text {rail }} \cdot(1-\alpha)\right] \cdot \mathrm{d}_{\mathrm{i}} \cdot \mathrm{q}_{\mathrm{it}}
$$

The overall GHG emissions ( $\mathrm{W}_{\text {all }}, \mathrm{kg}$ ) are the sum of the emissions associated with harvesting/forwarding and transportation:

$$
\mathrm{W}_{\mathrm{all}}=\mathrm{W}_{\mathrm{h}}+\mathrm{W}_{\mathrm{tr}}
$$




\section{Model Application and Results}

The utility of the supply chain simulation model may be demonstrated by considering the location of a biorefinery in the Lower Peninsula of Michigan (the L.P.). Nine potential biofuel facility sites in the L.P. were preselected by employing GIS-based methods. For the region of interest, 51 harvesting areas have biomass that is accessible. Of these 51 harvesting areas, only 10 have no railway access. Figure 7a shows the nine biomass feedstock demand locations (facility sites) that were considered. Since harvesting areas at a great distance from a facility site would require significant transportation costs, only harvesting areas within 100-mile radius of a facility location were considered. Figure 7b shows the 37 biomass harvesting areas for the Manton facility (demand) location.
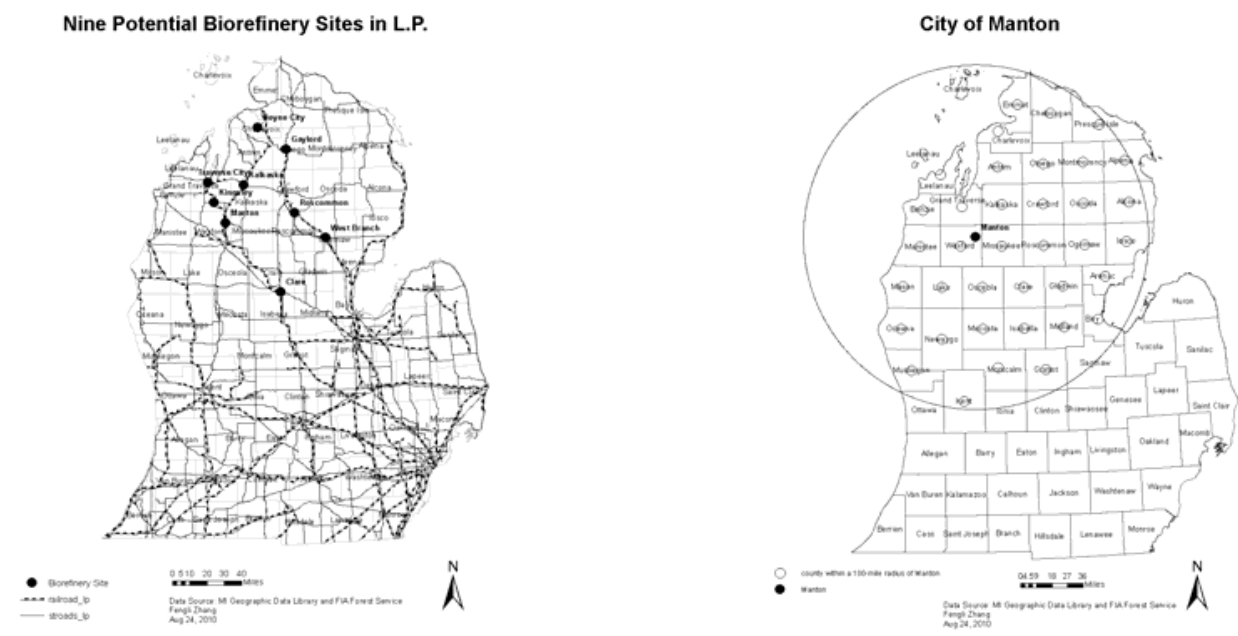

Figure 7: Biomass feedstock demand and supply locations

(a) Biomass feedstock demand locations in the L.P.

(b) Biomass feedstock supply locations for Manton

\subsection{Data Collection}

Specific data collected for the study region includes the potential biofuel facility locations, biomass harvesting plans, spring breakup details, cost intensity, fossil energy consumptions intensity, and GHG emissions. A plan for biomass harvesting (biomass availability for biofuel production) was estimated based on historical harvesting data. Spring breakup considerations are dictated by Michigan state law that indicates that the months of March, April, and May are automatically reduced loading months, but the statute also allows the Michigan Department of Transportation (MDOT) and each county road commission to implement restrictions earlier or suspend reduced load requirements, depending upon weather conditions [11]. Since spring breakup ends early in the L.P., an assumption is that March and April are included in the spring breakup. Other assumptions are as follows.

- Harvesting sites

o Harvesting sites are distributed across a 100-mile radius of a biorefinery;

o Harvesting sites are defined on a county-basis. The centroid of each county serves as the point from which biomass is transported to the processing facility;

o Daily biomass recovery at harvesting areas is approximately equal to the daily demand at the biorefinery for about half the year; the recovery must be higher in the four months before spring breakup and is negligible for the two month spring breakup duration;

o The biomass harvesting plans define the amount (tons) of biomass feedstock to be harvested at each harvesting site per week;

o It is assumed that no feedstock will be transported over the Mackinac Bridge from the Upper Peninsula of Michigan (the U.P.) to the L.P. Rather, it is assumed that feedstock generated in the U.P. will be consumed by U.P.-based activities;

- $\quad$ Biorefinery

0 The biorefinery is located in the center of the harvesting region;

o For a biorefinery producing 50 million gallons of ethanol per year (MGY), the daily demand for biomass feedstock is about 2,860 green tons (conversion factor is approximately 50 gallons of biofuel per green ton of biomass). These estimates are based on the assumption that the biorefinery operates 
350 days (50 weeks) per year with 2 weeks for maintenance;

- $\quad$ Spring breakup

o The spring breakup is assumed to be March 1 through April 30 for all the harvesting areas;

0 The rate of feedstock harvesting and delivery will remain constant during the period from June 1 through October 31. The rate of biomass production will increase from November 1 through the end of February in anticipation of the spring breakup. Starting with November $1^{\text {st }}, 50 \%(2,860 / 2=1,430$ green tons) more biomass need to be harvested and delivered to biorefinery every day to build up the inventory;

o Demand for biomass feedstock at biorefinery during spring breakup is pulled from on-site inventory only;

- Transportation

o The transportation distances from the harvesting areas to the biorefinery are calculated using rectilinear distances;

o Biomass feedstock is delivered by diesel truck or diesel railcars. This is important because we are interested in estimation of energy consumptions and GHG emissions associated with biomass transportation;

o Trucks/railcars return to the harvesting areas carrying an empty load;

o Trucks/railcars conduct self loading and unloading. No additional/independent loaders/unloaders are needed;

o Every truck and railcar has a capacity of 75 tons;

o For harvesting areas with rail access, $20 \%$ of biomass is delivered via rail and $80 \%$ by truck;

- Other

o Biomass is transported immediately after being harvested which leaves no time for drying;

o The moisture content remains 50\% throughout the supply chain; therefore biomass weight delivered from harvesting areas to biorefinery stays the same;

o No dry matter loss, for example, weight loss during storage due to insect infestation, is taken into account throughout the supply chain.

\subsection{Results}

A pilot run was made for a biofuel facility located in the city of Manton, Michigan. The start date for the simulation was set as Nov $1^{\text {st }}, 2010$ and the model run length was 350 days. The time step during the simulation was set as one day. The on-site biomass inventory (tons) changes as a function of time following the pattern demonstrated in Figure 8. It is obvious that there are three phases in the chart. For the first 16 weeks (112 days), the harvesting areas produce $50 \%$ more biomass every day than the daily demand to build up the inventory. The inventory peaks at 150,000 tons on day 112 . Starting with the $17^{\text {th }}$ week (day 113), the spring thaw starts and no biomass is allowed to be transported. The daily requirement for biomass at the biorefinery is met by pulling biomass from the on-site inventory. The spring breakup ends at the end of $24^{\text {th }}$ week (day 168) and since then a regular operation plan (daily demand is met by daily transportation) is executed, and the on-site inventory is essentially zero.

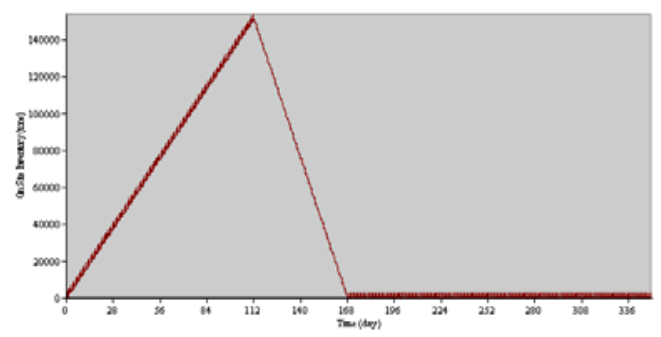

Figure 8: On-site inventory tracking

The system performance measures are listed in Figure 9. Three categories of results are included: the delivered feedstock cost (the $1^{\text {st }}$ column), energy use (the $2^{\text {rd }}$ column) and GHG emissions (the $3^{\text {rd }}$ column). The total delivered feedstock cost is about 18.8 million dollars and the average delivered feedstock cost is 18.8 \$/ton. The stumpage cost represents about $50 \%$ of the total delivered feedstock cost while the storage cost makes up only $4.5 \%$. The total energy use is about $241,110 \mathrm{GJ}$ and the average energy consumption is about $241.1 \mathrm{MJ} /$ ton of biomass. The energy use associated with harvesting/forwarding represents about $57 \%$ of the total energy consumption, and truck 
operations account for about 41\%. The GHG emissions are about 21.7 million $\mathrm{kg}$ and the average energy consumption is about $21.7 \mathrm{~kg} / \mathrm{ton}$. The GHG emissions associated with harvesting/forwarding are about $51 \%$ of the total energy consumption, while truck operations represent about $47 \%$.
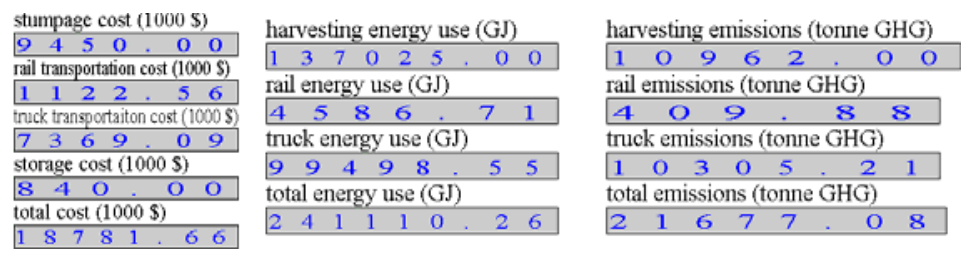

Figure 9: System performance indicators

\section{Conclusions}

A supply chain model has been developed for biomass supply to biofuel facilities. The model considers key activities of the supply chain, including biomass harvesting/forwarding, transportation, and on-site storage. The supply chain is driven by both daily demand for biomass feedstock at a biorefinery and daily biomass recovery at harvesting sites. The model is evaluated using three key performance indicators: the delivered feedstock cost, energy consumption, and GHG emissions. The model also considers the average age of the in-field biomass inventory and road restrictions associated with spring thaw that limit use of truck transportation on certain roads. The utility of the supply chain simulation model has been demonstrated through a simulation that considers a supply chain for biomass feedstock for several biorefinery locations in the L.P. of Michigan.

\section{Acknowledgements}

This research was supported through an agreement with the Michigan Economic Development Corporation with funding from the U.S. Department of Energy award DE-EE-0000280.

\section{References}

1. Iakovou, E., Karagiannidis, A., Vlachos, D., Toka, A., and Malamakis, A., 2010, "Waste biomass-toenergy supply chain management: A critical synthesis,” Waste Management (in press).

2. Rentizelas, A.A., Tatsiopoulos, I.P., and Tolis, A., 2009, "An optimization model for multi-biomass trigeneration energy supply,” Biomass and Bioenergy, 33, 223-233.

3. Arena simulation software, Available at: http://www.arenasimulation.com/.

4. Biomass Research and Development Board, National Biofuels Action Plan, Biomass Research \& Development Initiative, 2008.

5. Hess, J.R., Wright, C.T., and Kenney, K.L., 2007, "Cellulosic biomass feedstocks and logistics for ethanol production," Biofuels, Bioproducts \& Biorefining, 181-190.

6. Idaho National Laboratory (INL), 2006, Bioenergy Technology, Available at: http://www.inl.gov/bioenergy/projects/d/1006_ch2m.pdf.

7. Sandia National Laboratories (SNL), and General Motors' R\&D Center, 2009, "90-Billion Gallon Biofuel Deployment Study: Executive Summary,” Available http://www.greenbiz.com/sites/default/files/document/Exec_Summary02-2009.pdf.

8. West, T., Dunphy-Guzman, K., Sun, A., Malczynski, L., Reichmuth, D., Larson, R., Ellison, J., Taylor, R., Tidwell, V., Klebanoff, L., Hough, P., Lutz, A., Shaddix, C., Brinkman, N., Wheeler, C., and O’Toole, D., 2009, "Feasibility, economics, and environmental impact of producing 90 billion gallons of ethanol per year by 2030", Available at: http://www.sandia.gov/news/publications/white-papers/90-Billion-GallonBiofuelSAND2009-3076J.pdf.

9. Reynolds, R.E., 2002, “Infrastructure Requirements for an Expanded Fuel Ethanol Industry,” South Bend, IN: Oak Ridge National Laboratory Ethanol Project, http://www.ethanolrfa.org/objects/documents/94/dai.pdf.

10. Slade R., Bauen A., Shah N, 2009, "The greenhouse gas emissions performance of cellulosic ethanol supply chains in Europe,” Biotechnology for Biofuels 2:15.

11. Michigan State Policy, http://www.michigan.gov/msp/0,1607,7-123-1586_1710-87560--,00.html, accessed on Sep. 26, 2010. 